\title{
TECHNICAL CHALLENGES OF A LIGHTWEIGHT, SCALABLE, GLOBAL PAYWALL SYSTEM
}

\author{
By \\ Puneeth Anandaraj
}

\author{
A thesis \\ submitted to the Victoria University of Wellington \\ in partial fulfilment of the requirements for the degree of \\ Masters of Advanced Technology Enterprise
}

Victoria University of Wellington 



\section{Abstract}

This thesis presents the technical challenges that were faced while building a lightweight, scalable, global news paywall system. It also presents the common events while establishing a start-up company and also its unique events while building the start-up, Ripple Media Ltd. The project was based on a research within the Victoria University's School of Information Management, "Digital Commons or Digital Enclosures: The Future of Online Content Distribution." The project focuses on providing a platform that would solve the problems of online distribution and monetisation strategies. Ripple Media Ltd has conducted a market research that would give insights on news monetisation and building a product / platform addressing the online content distribution. 



\section{Acknowledgement}

I would like take this opportunity to thank all those people who have made this thesis possible through support, guidance and involvement through MATE program.

Firstly, I would like to thank Professor Kate McGrath for starting this course that would provide people to explore their entrepreneurial skills. I also would like to thank the course coordinators at different time, Dr Paul Smith, Prof David Bibby and Miss Jenny Douche for overseeing the progress of my thesis.

Thanks to Mr Michael Elwood-Smith for overseeing the business development and product development as a project mentor and to my supervisor Dr Stuart Marshall who guided me through the thesis.

To my fellow MATE participants who shared their knowledge and especially to Alex Clark for trusting my decisions. It's been a pleasure working with you all.

Lastly, to all my family and friends. This thesis is only due to their support and encouragement.

Puneeth Anandaraj

Wellington, February 2015 



\section{Table of Contents}

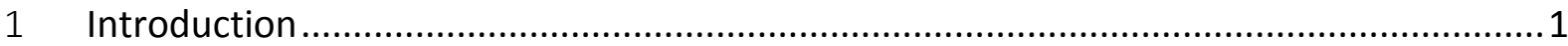

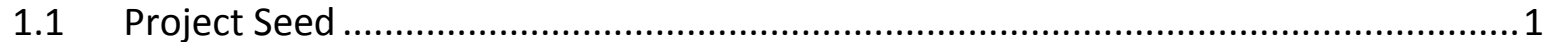

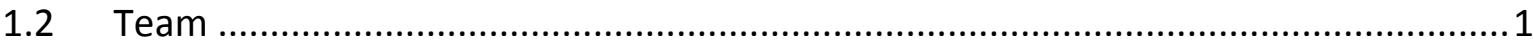

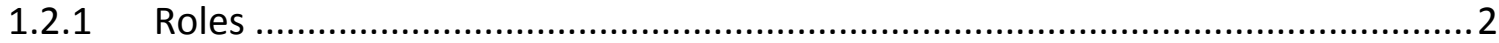

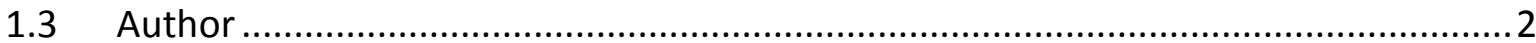

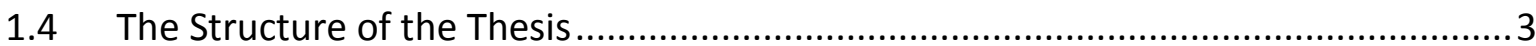

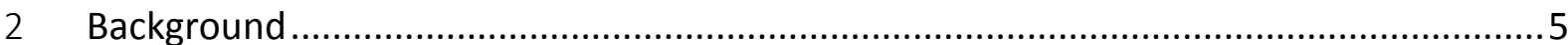

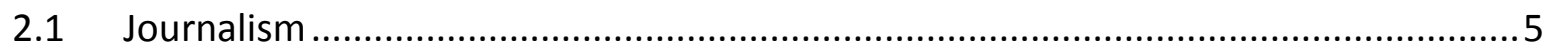

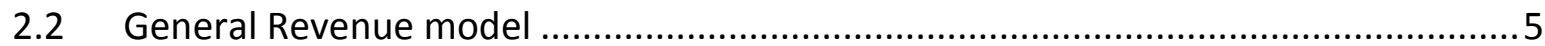

2.3 Current Problem with the Revenue Model ...................................................... 5

2.4 The Decline of Online Advertisement Business ...................................................

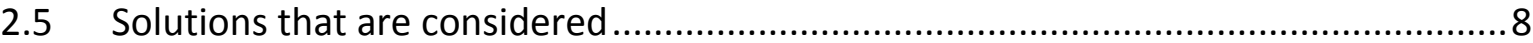

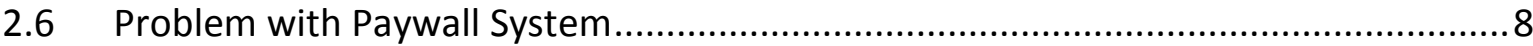

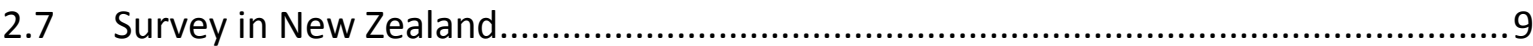

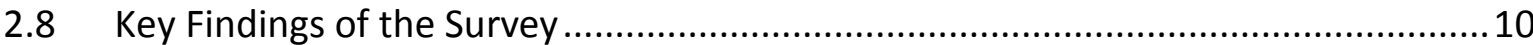

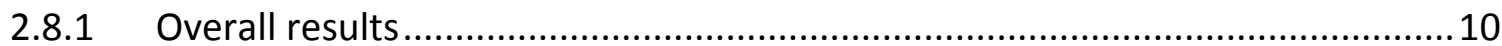

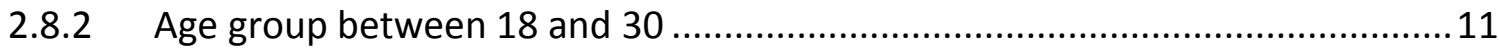

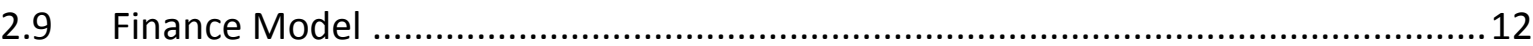

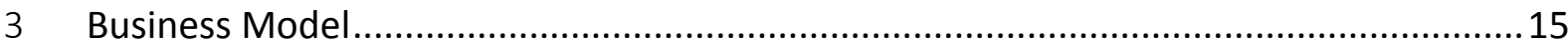

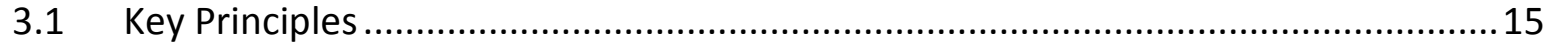

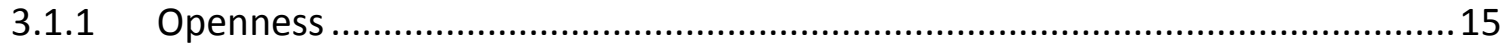

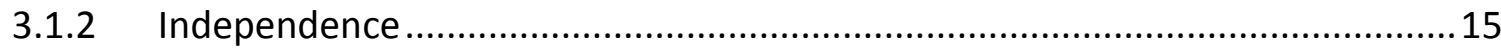

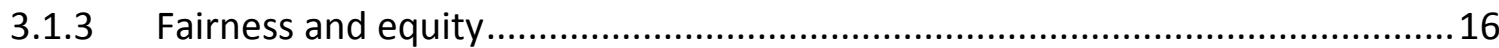




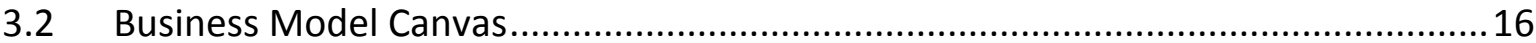

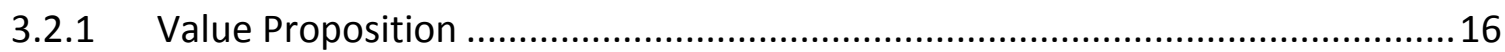

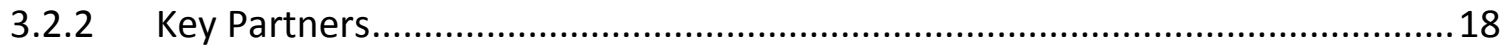

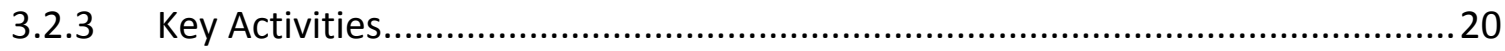

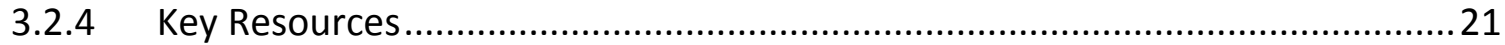

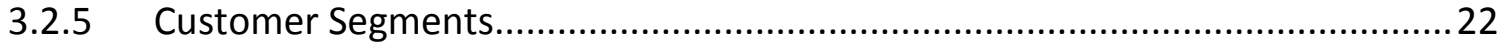

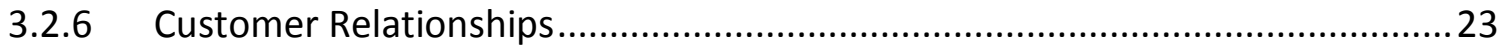

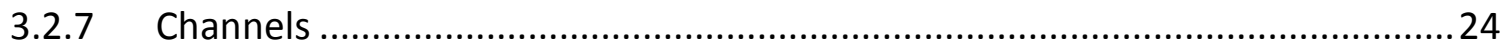

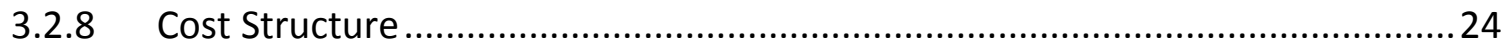

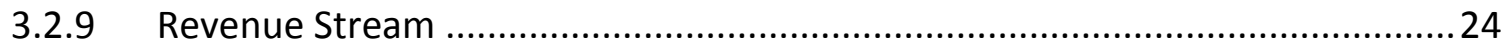

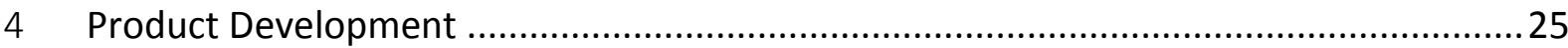

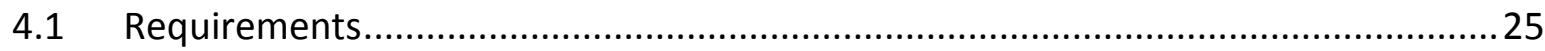

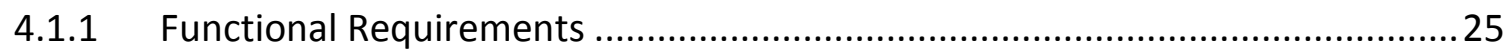

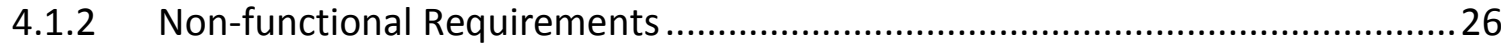

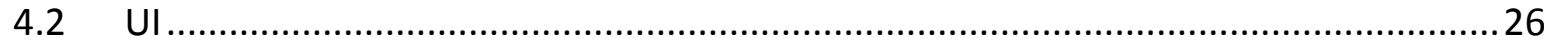

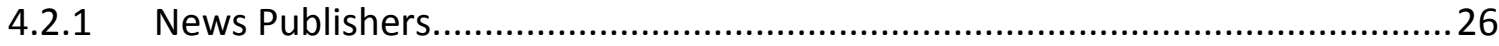

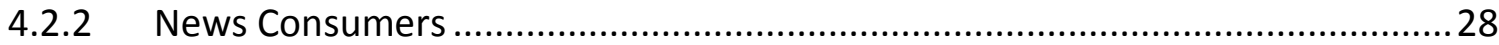

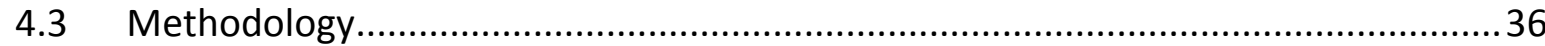

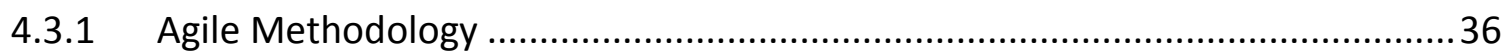

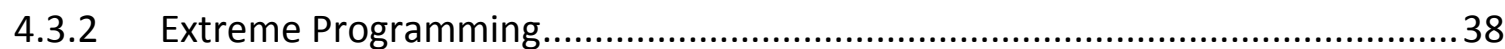

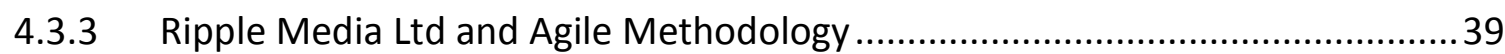

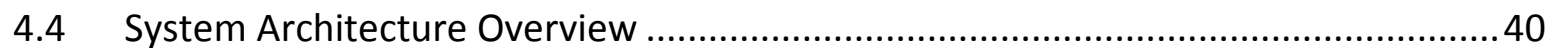

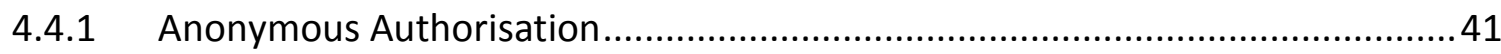

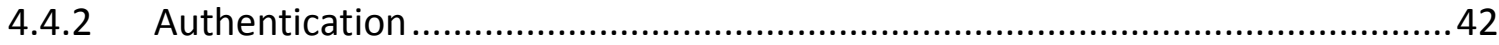

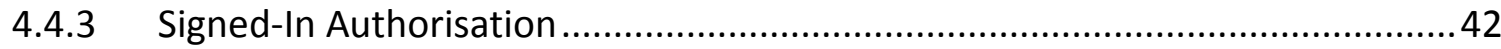




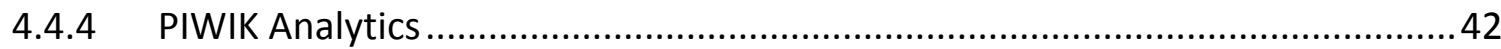

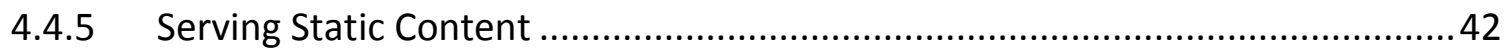

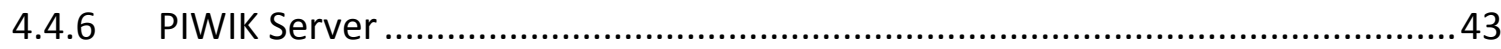

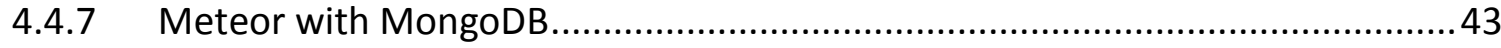

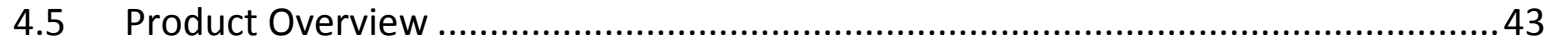

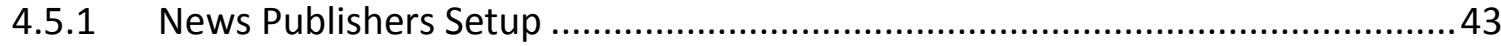

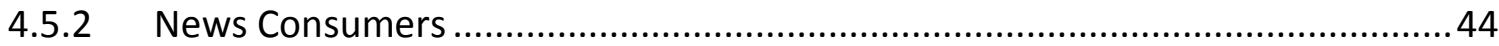

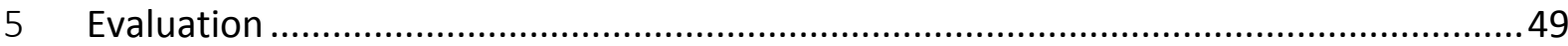

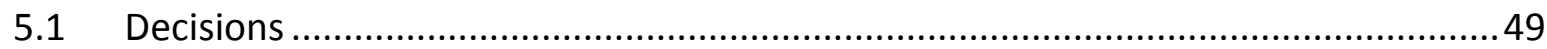

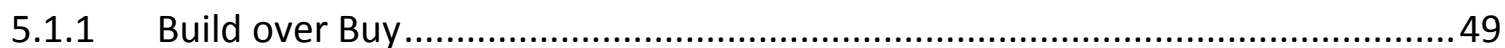

5.1.2 Open source over Proprietary software ......................................................... 49

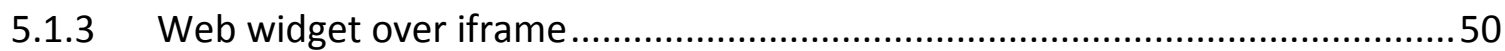

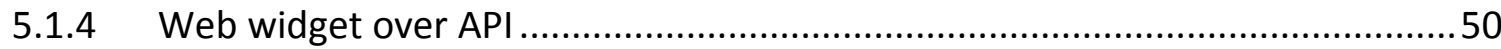

5.1.5 PIWIK over Google Analytics / Google Universal Analytics ...............................51

5.1.6 Meteor and MongoDB over other server technologies ..................................51

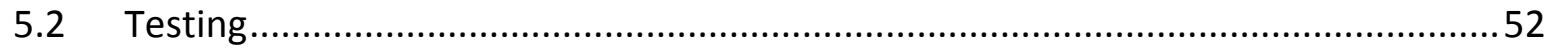

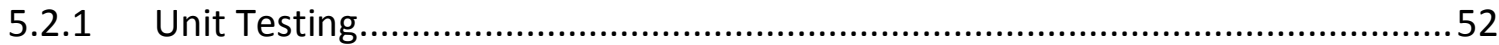

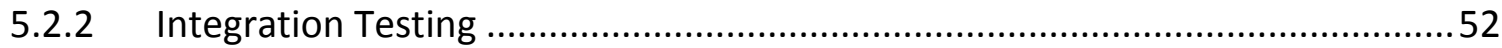

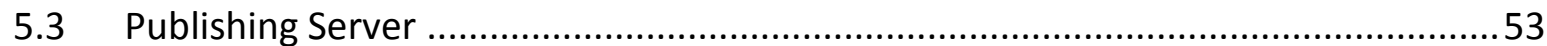

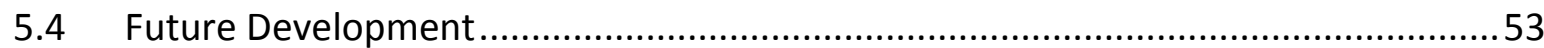

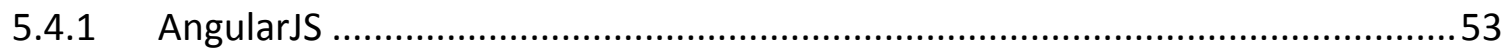

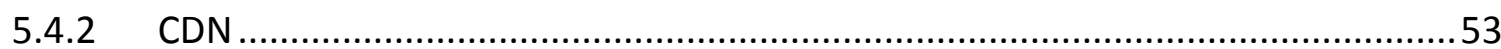

6 Summary

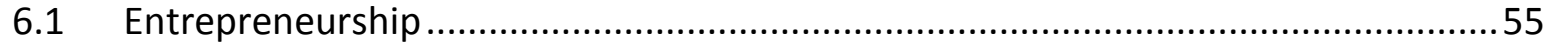

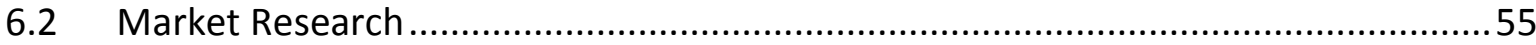




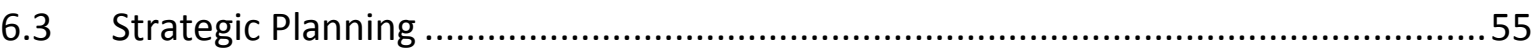

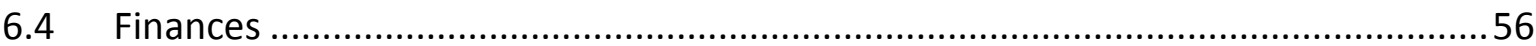

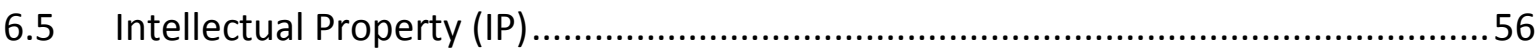

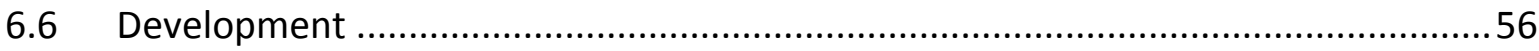

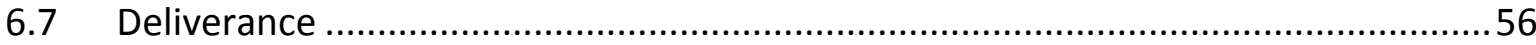

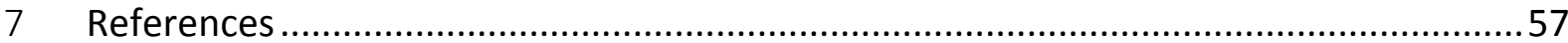

\section{List of Figures}

Figure 1: Print and Online Advertisement Revenue. Source - Newspaper Association of America

Figure 2: Newspaper revenue through advertisements in New Zealand. Source - Advertising standards Authority 7

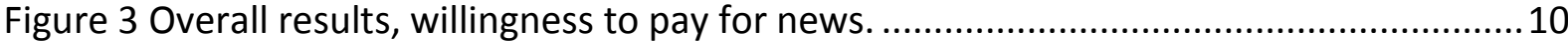

Figure 4: 18-30 year olds, willingness to pay for news. .....................................................11

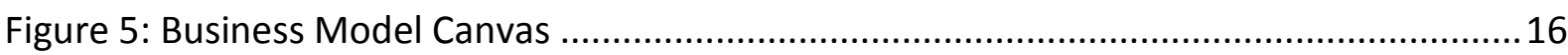

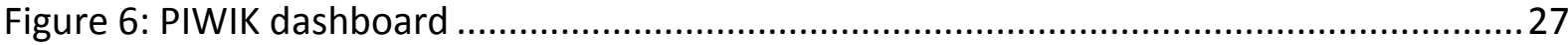

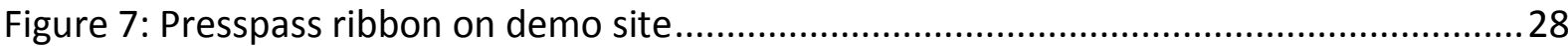

Figure 8: Presspass ribbon enabled on a news publisher's website .......................................30

Figure 9: Anonymous User before viewing an article …..................................................... 30

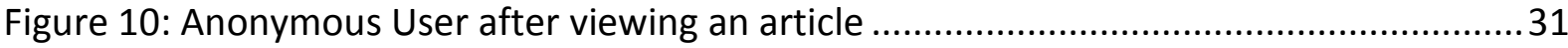

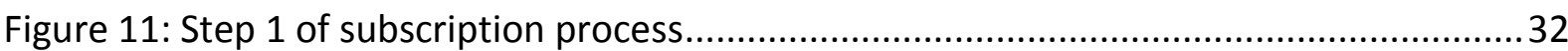

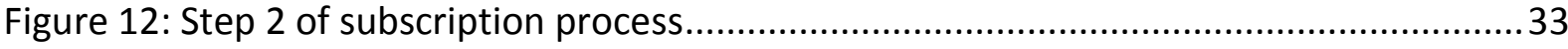

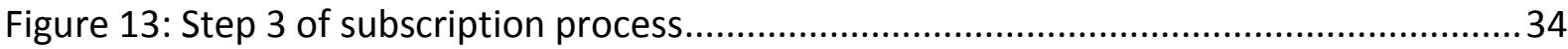

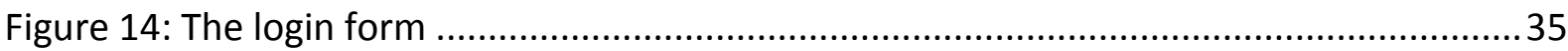

Figure 15: Architecture Diagram of Presspass ................................................................... 41 


\section{Introduction}

Masters of Advanced Technology Enterprise (MATE) program at Victoria University of Wellington, New Zealand, requires students to complete a thesis focused on their role and the outcome of the team / group project they have been working on. My role within the team was to develop the software product based on the requirements gathered during the market research that was conducted to solve a real world problem. The aim of this thesis is to present my personal reflection based on my role and the outcome of the software development.

\subsection{Project Seed}

The Ripple Media project has been seeded from a research conducted by Alex within Victoria University's School of Information Management. The working title of his research is "Digital Commons or Digital Enclosures: The Future of Online Content Distribution." His research has involved interviews with 26 authors, journalists, musicians, publishers, and media commentators, providing diverse insights into how people think content should be created, distributed and funded in a digital environment.

The Ripple Media Ltd.'s project henceforth referred to as the Presspass system is focused on creating a platform that improves digital media by solving some of the major problems raised during this research, particularly in regards to content distribution and monetisation.

Presspass system seeks to improve the way that news journalism is distributed and monetised. It is a shared subscription and paywall platform that can be integrated with third-party news websites, allowing these websites to offer 'pay-once-access-all' subscription packages for multiple partner websites.

\subsection{Team}

MATE program suggested its interdisciplinary members to form groups or teams who would work together in commercialising an advanced technology. Alexander Colin Clark, a MATE student and research assistant at Victoria University of Wellington and I, the author of this thesis, decided to form a team that would research and develop an application to change the way the news is funded. The team called itself and henceforth referred to as Ripple 
Media Ltd. A company by that name was registered and incorporated on the $5^{\text {th }}$ of May 2014 with the company number, 5189621.

In April-May 2014, Paul Smith, an open source developer at New Plymouth joined on-board with Ripple Media Ltd. Paul does not belong to the MATE program however, Paul is equally responsible on the success of the project.

\subsubsection{Roles}

Alex is the founder of Ripple Media Ltd and he is also the overseer of the marketing, client acquisition and business development.

I'm the Founding Developer at Ripple Media Ltd who oversees, and personally involves in the development and deliverance of the product to the customers.

Paul is a developer at Ripple Media Ltd who develops any required components to the software product.

\subsection{Author}

I, Puneeth Anandaraj completed my Bachelor of Technology at Amrita Vishwas Vidyapeetam, Bangalore, India majoring in Computer Science. Thereupon, started to work for Infosys Technologies Ltd, India in the Education and Research Department. Training people and developing applications on Microsoft .NET technologies, it gave me valuable experiences in Windows, web and mobile technologies.

To gain more knowledge on software development, I studied Post Graduate Diploma at Victoria University of Wellington, New Zealand majoring in Computer Science. Consequently, I started to work for North South GIS (NSG), New Zealand as a software developer.

Previous to MATE program, I incorporated 2 start-up companies that did not reach as a stable business due to various setbacks in the business / project. MATE program gave me an opportunity to identify common pitfalls that any start-up company would face and at the same time provide guidance and support to overcome those pitfalls.

I present in this thesis my experiences on successfully sketching out the business model and building a viable solution to a real world problem. 


\subsection{The Structure of the Thesis}

As this is a new course, there are no direct precedents for writing a thesis but the dominant interdisciplinary intent of the course let to the exploration of market research, design, development and deliverance. The thesis is structured to provide a sequential development of the product.

The second chapter focuses on the background information of journalism in general and how the news publishing industries generated their revenue.

The third chapter describes the business model of Ripple Media Ltd and also explains in detail the Business model canvas that was sketched out to provide a visual representation of the model.

The chapter four details out the product development process and its components.

The fifth chapter evaluates the product and also illustrates the decisions made by the team on methodology, tools, technology, processes and design patterns. It also gives the testing methods and future enhancements of the Presspass system.

The last chapter concludes on my learning and skills acquired in MATE program and Ripple Media Ltd. 



\section{Background}

\subsection{Journalism}

Journalism is collecting, processing, and distribution of news and information to a related audience. The recorded history of journalism dates back to 59BC where the Roman Empire by the order of Julius Caesar, published Acta Diurna ("Daily Acts"), or government announcement bulletins which were carved in stone or metal and publicised to the locals. In 1665 , the world saw its first qualified newspaper, London Gazette which was periodically printed twice a week. As the time progressed, the Journalism has grown by using improved and specialised techniques for collecting the information on a regular basis, immaculate processing, and faster distribution of news through different mediums like newspapers, radio, television and internet.

\subsection{General Revenue model}

In 1704 Boston Newsletter published its first advertisement, an announcement seeking a buyer for an Oyster Bay, Long Island (Advertising Age, 1999). Due to political influence, initially it was heavily subsidised by the British Government with minimal circulation. After the first advertisement publication, Boston Newsletter started to focus on advertisement as an impeccable revenue model. Later many other News publishers adapted this model for generating revenue and eventually news industries made the newspapers free for the consumers (the general public) and charged business for posting an ad on their newspapers. Currently, the same revenue model of print newspapers has been incorporated to online newspapers.

\subsection{Current Problem with the Revenue Model}

Although the news industries are generating revenue through print and online newspapers, the statistics show that for every $1 \$$ gained in digital (online) advertising, $\$ 16$ worth of print advertising is lost (THOMPSON, 2013).

Newspaper Association of America has published the revenues generated by both print and online advertisements by all the news industries in the United States of America. According to their statistics, print newspapers ads have fallen two-thirds from $\$ 47.5$ billion in 2005 to 
\$17 billion in 2013 and online newspaper ads have grown from 2 million in 2005 to 3.4 million in 2013 (Newspaper Association of America, 2014). Below is the chart that illustrates the age old trend of newspaper industries' revenue model through advertisement.

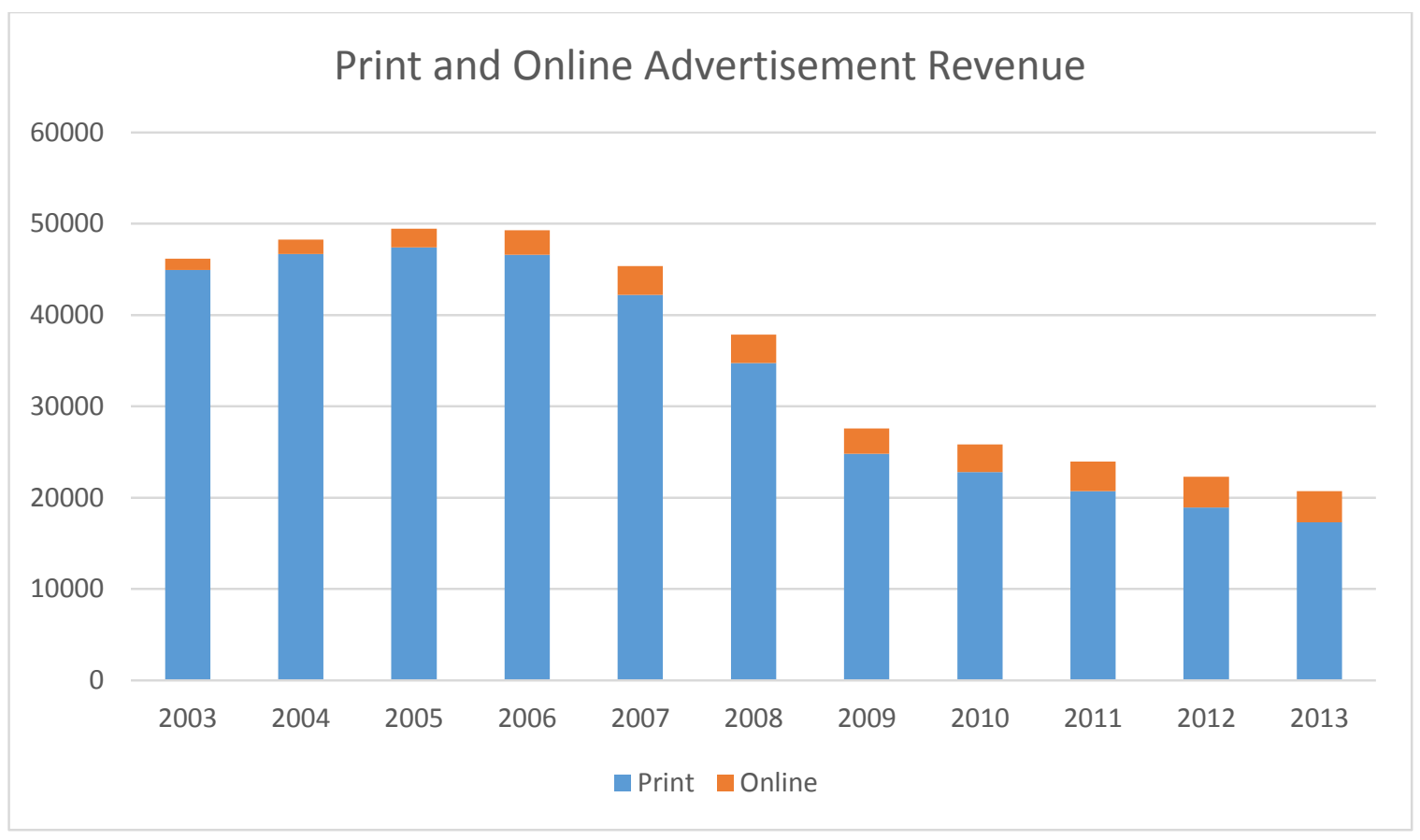

Figure 1: Print and Online Advertisement Revenue. Source - Newspaper Association of America

This is what the economist calls it as "Economy Destruction". The revenue from digital advertisement hasn't replaced the print advertisement causing a major economy crash for the news industries (Phillips, 2014). 


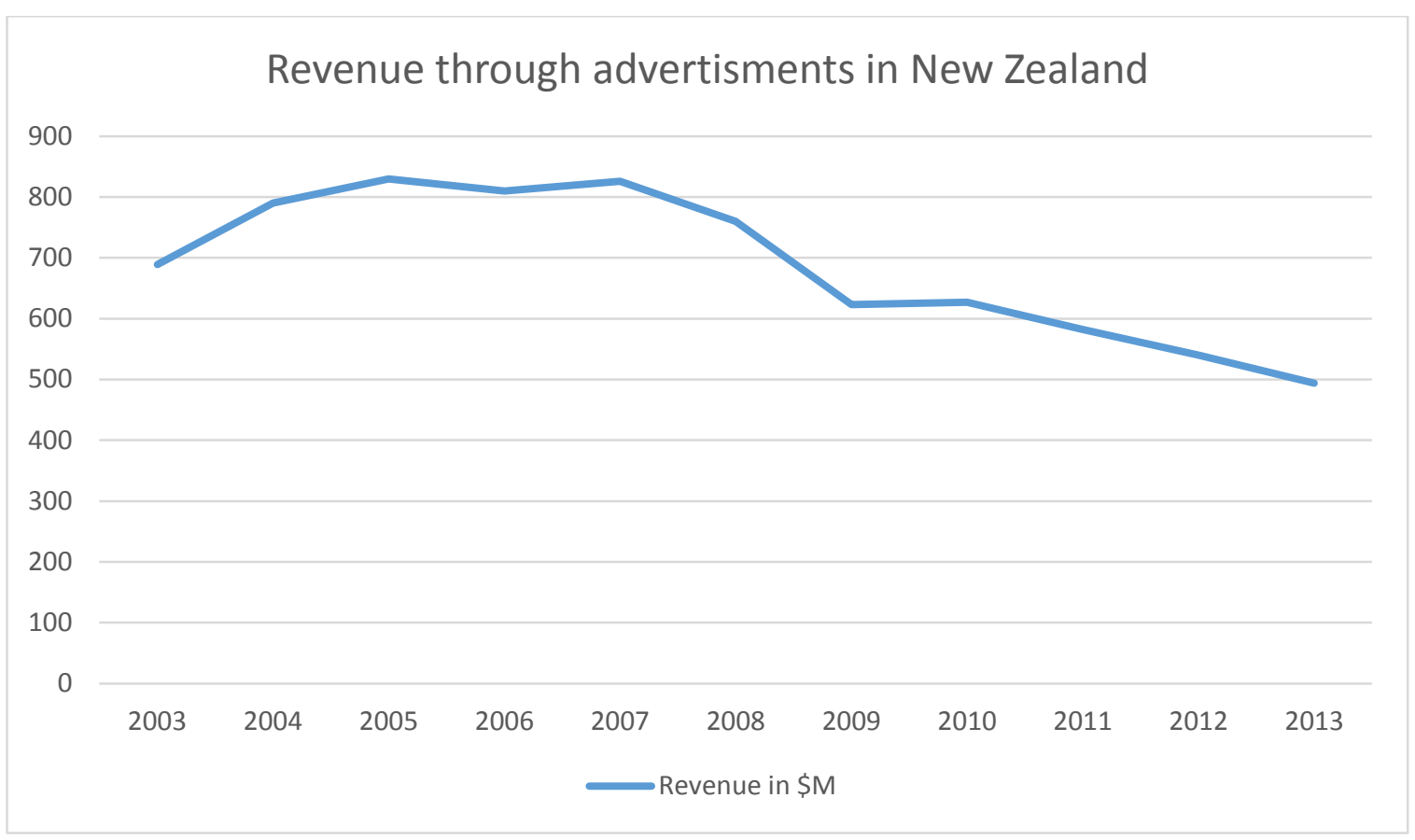

Figure 2: Newspaper revenue through advertisements in New Zealand. Source - Advertising standards Authority

In New Zealand, APN News \& Media and Fairfax NZ are the two major news agencies with Fairfax circulating about $48.6 \%$ of newspapers across the country. Advertising Standards Authority (ASA) has published the New Zealand Advertising Industry turnover by newspapers (Advertising Standards Authority, 2013). The statistics have shown that the news industries in New Zealand have lost almost one-third of their revenue from \$830 Million in 2005 to \$494 Million in 2013.

Due to lack of funds and revenue, news industries are hit by major consequences. The top journalists are fired or they are waged down leading to poor quality of the articles (MCBETH, 2013).

\subsection{The Decline of Online Advertisement Business}

The decline is not just in the news industry, but also in the entire advertising industry. In 2012, there was a 16\% decline in the value of the Google advertisement (GREENFIELD, 2012). Greenfield cites a Claire Cain Miller's article - As Google Changes, Its Revenue Keeps Rising (MILLER, 2012) pointing out mobile being the main culprit for the decline in the advertisement value as the clicks on the mobile ads cost $40 \%$ less than the desktop version. The other reason is also the use of Ad blockers by users that would block advertisement on their web browsers. With over 50 Million download, AdBlock blocks all the advertisements 
on the user's browser reducing the value of the advertisements (AdBlock, 2015). Mobile and Ad blockers being the two major reasons for the decline in the advertisement value, the news industry has sorted out for an alternative revenue model.

\subsection{Solutions that are considered}

Although many news industries are still generating their revenue through advertisements, some have moved further by implementing a paywall system in their websites which provide news online to the public.

In March 2011, New York Times controversially implemented a metered paywall system which allowed the consumers (news readers) to view 20 free articles per month before becoming a paying subscriber and 25 free articles if accessed through a search engine. This model was termed as "soft" paywall system - allowing free articles before becoming a paid subscriber.

New Zealand's APN and Fairfax have a similar idea of implementing a paywall system on their online news websites - www.nzhearld.co.nz and www.stuff.co.nz respectively (Marketing Monitor, 2014). Their news channels have hinted a paywall system, but at the moment (time of writing this thesis) no particular business model nor a date of launch was announced by either of the companies.

\subsection{Problem with Paywall System}

While news industries are heading towards paywall system to their online publications, Ripple Media Ltd was leaning towards collaborating the publishers for improving the quality of articles and simultaneously easing the process of accessing the news for the consumers. We had two main assumptions regarding the implementation of paywall in New Zealand.

1. If either of the news publishers in New Zealand implemented the paywall system first, the consumer traffic would move to the other due to free access to news.

2. If both the news publishers implemented the paywall system, the news consumers may limit their news consumption to one news publisher or may have to pay for both to get more insights to particular event that's been published. 
3. The two news publishers in New Zealand cannot tie together to provide a single paywall system as it is against the Anti-Competitive Law under Commerce Act 1986 (Commerce Commission New Zealand, n.d.).

Our first assumption was never validated and it remained as an opinion by our team. However, the second and the third assumption were validated based on a survey that was conducted by our team, which will be discussed in the next section.

\subsection{Survey in New Zealand}

In March-April 2014, a survey was conducted by our team - Ripple Media Ltd with a total of 457 respondents from New Zealand. Among these, 30 were face-to-face and the remaining were online. The participants were random and 427 respondents received an online survey invitation through social networking sites. Since the majority of the respondents were online users, we can consider that these users read news mostly through online. The survey questionnaire is attached in the reference section. The objective of this survey was to explore the proclivity of the people towards paywall system and 10 news monetization strategy:

1. Pay-per-article

2. Payment to remove the advertisement

3. Payment for a mobile app

4. Subscription to one New Zealand news website

5. Subscription to New Zealand package

6. Subscription to global package

7. Subscription to news + video + music package

8. Crowdfunding

9. Donations

10. Payment for premium content

There were three sections of the questionnaire. The first section focused on the receiving respondents' general information like age, income and their contact details if they wished to be contacted. The second section questioned the users' news reading habits and the third section mainly focused on users' thoughts on funding journalism. Different scenarios based 
on the 10 news monetization strategies were asked to the users and their tendency towards these strategies was recorded.

\subsection{Key Findings of the Survey}

After consolidating the results, no substantial support was received for some of the monetization strategies like pay-per-article, pay to remove the advertisement, pay for a mobile app, crowdfunding, donation and paying for the premium content. Other strategies gave us insights on the users' inclination towards news funding.

\subsubsection{Overall results}

The survey showed that the consumers' willingness to pay for the news significantly increased when multiple publishers were packed together.

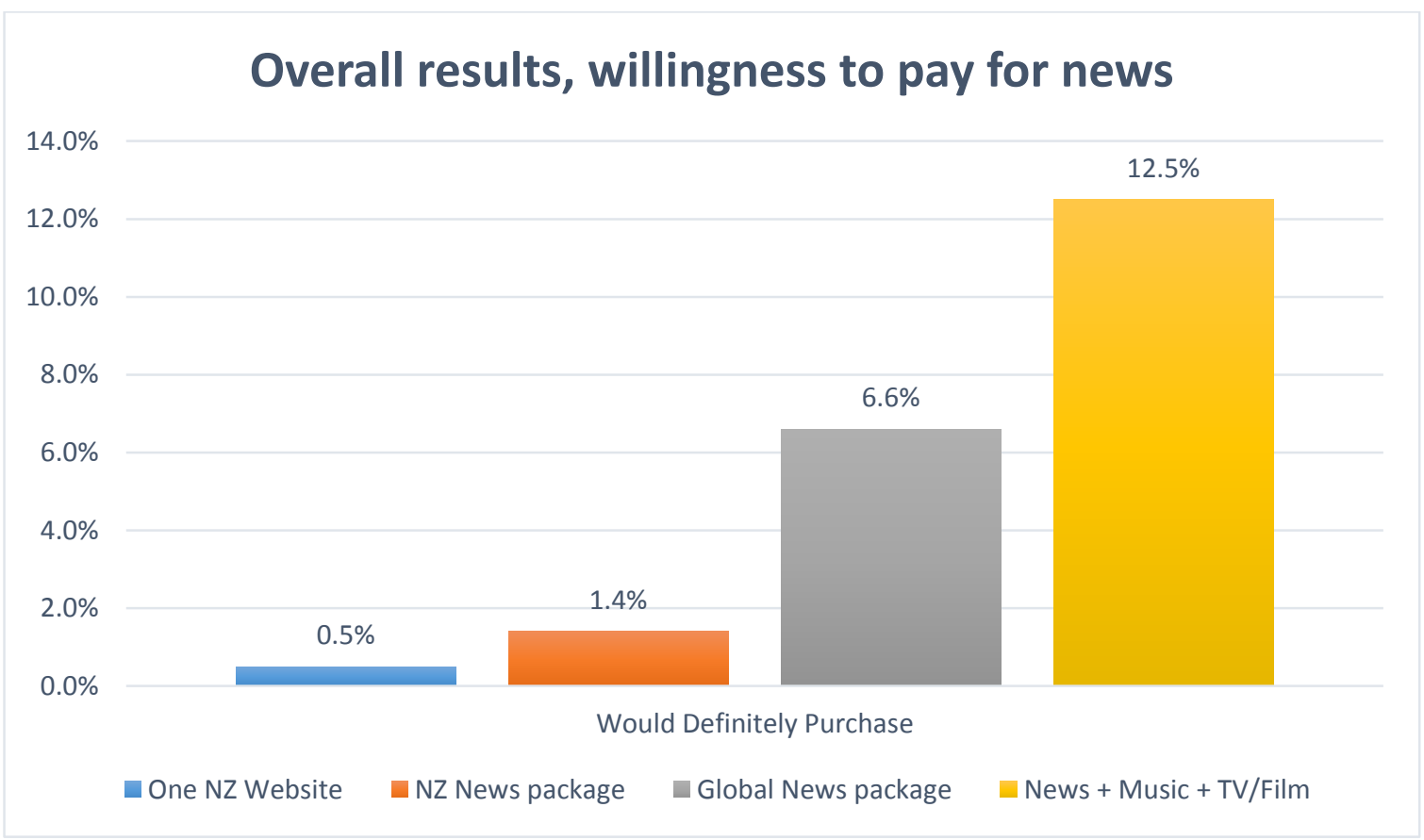

Figure 3 Overall results, willingness to pay for news.

1. $0.5 \%$ of consumers said that they would definitely purchase a subscription to a single New Zealand news website.

2. $1.4 \%$, that is about $2.8 \mathrm{x}$ increase in number of people said they would subscribe to NZ News package (multiple NZ publishers package). 
3. $6.6 \%$, that is about $13 x$ increase in number of people said they would subscribe to the Global News package (multiple NZ and global publishers package).

4. $12.5 \%$, that is about $25 \mathrm{x}$ increase in number of people said they would subscribe to Global News and other entertainment package.

Overall, the percentage of respondents willing to pay more than $\$ 10$ per month for a subscription doubled when offered a package of all NZ news websites. The percentage increased $3 x$ when offered a global news package.

\subsubsection{Age group between 18 and 30}

We also noticed another interesting fact from this survey. The age group between 18 and 30 are the least likely to subscribe to the single news publisher package. However, their willingness to pay drastically increased when multiple entertainment and the News were bundled as a single package. Below is the graph that illustrates the willingness to pay for news between the age group 18 and 30 .

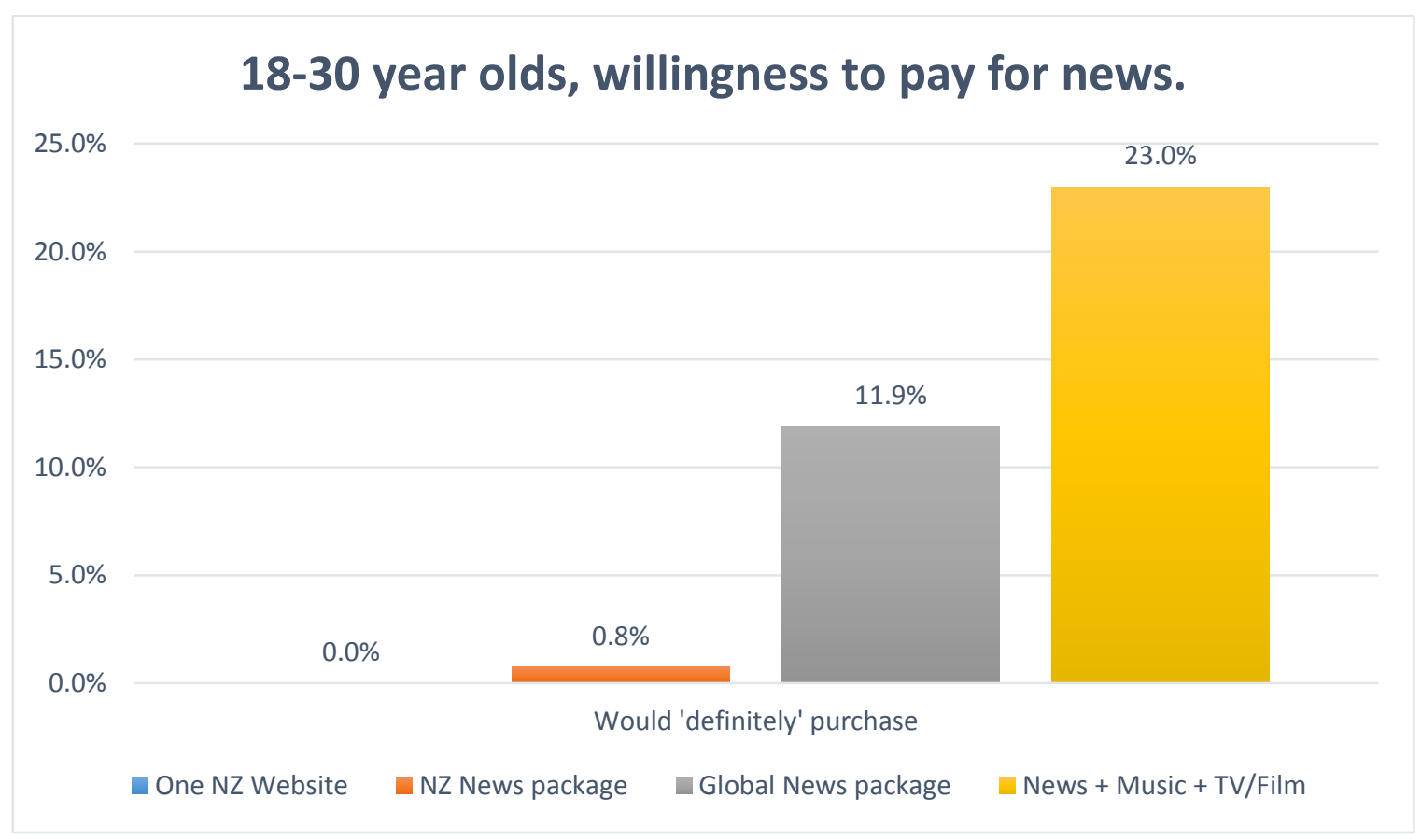

Figure 4: 18-30 year olds, willingness to pay for news. 
1. Interestingly, no one between the age group 18 and 30 said they would definitely purchase a subscription package to one NZ website.

2. $0.8 \%$ said they would definitely subscribe to the NZ News package.

3. $11.9 \%$, which is a drastic increase in consumers who said that they would definitely subscribe to the Global News package.

4. $23 \%$, which is again a drastic increase in consumers who said that they would definitely subscribe to the News and other entertainment packages.

The percentage of 18 to 30 year olds willing to pay more than $\$ 10$ per month increased $3 x$ when offered a package of all NZ news websites. The percentage increased $6 x$ for a global news package.

\subsection{Finance Model}

Ripple Media Ltd team spent a considerable amount of time in evaluating and redesigning the financial model that would help both Ripple Media Ltd and the partner publishers including the global publishers. In the beginning, the model will help the publishers to sustain their business through Ripple Media Ltd (paywall system) along with their advertising revenue. Through our assumption and estimation, the publishers will be generating continuous and stable revenue through this model.

According to APN's 2014 annual report, 2.9 million unique users aged above 15 access their news website, stuff.co.nz every day. Based on these many users accessing news over internet, we can estimate the revenue generated by Ripple Media Ltd and the news publishing partners.

If $0.5 \%$ of 2.9 million users who said they would definitely pay only for a single news website with an assumption that $\$ 10$ per month per website, the news companies would generate 1.74 million per annum.

However, if $6.6 \%$ of 2.9 million users who said they would definitely pay for a global news package that was changed for $\$ 20$ per month, the total revenue would be 45.9 million per annum. With an assumption that $10 \%$ share goes to Ripple Media Ltd, $10 \%$ to global market and $40 \%$ for each New Zealand news publishers, the individual publisher can generate 20.67 million per annum. 
On the higher estimation, if all the $\mathbf{2 . 9}$ million users paid for the online news that was charged at $\$ 20$ for global package, the total revenue would be 696 million per annum. With the similar assumption of market shares, the individual New Zealand news publishers can generate 313.2 million per annum.

This is an added revenue that the news publishers including the global publishers can generate along with their online advertisement revenue and eventually stabilizing the growth. 



\section{Business Model}

Based on the results from the survey, Ripple Media Ltd team sketched out a business model which not only benefits the news consumers but also the news publishers. Our simple model was to collaborate the news publishers in New Zealand and some chief global publishers like New York Times, Huffington post, and others. The users can subscribe to either one New Zealand publisher or New Zealand news package or Global package. This allows them to subscribe to a package that is more convenient to them.

\subsection{Key Principles}

Our business model works on three key principles.

\subsubsection{Openness}

Open business is a type of enterprise model driven by openness movements like open source software, open contents, open tools and standards. The value is based on transparency, accountability and stakeholder inclusion. The business model is visible to both the contributors and non-contributors so that the business profits are distributed accordingly (Chesbrough, 2013). There are three main benefits of this model.

- Knowledge and key information is open and free to all the members and simultaneously all the members contribute and share knowledge for the development of the business.

- The finance is distributed accordingly based on the members' contribution to the growth of the business.

- The decisions are predominantly based on consensus and voting involving all the members through an open process.

\subsubsection{Independence}

The news publishers will have freedom on their news websites. Our model will not interfere with their news contents, advertisements or partner news channels. They have all the independence in the ways the contents are collected, improved or delivered and achieving a competitive news deliverance among the news publishers. 


\subsubsection{Fairness and equity}

The model will provide a fair and equal relationship with the news publishers. No publisher will or can have a superior relationship with Ripple Media Ltd. This equal treatment to all the publishers will enable us to have a strong collaboration.

\subsection{Business Model Canvas}

The Business Model canvas which was initially proposed by Alexander Osterwalder, is a visual chart with elements describing the finances, customers, value proposition and infrastructure for lean startups documenting their business model (Alexander Osterwalder, 2013). The template has helped Ripple Media Ltd to plan the business strategies and identifying the key aspects of the business.

Below is the template of the Business Model Canvas.

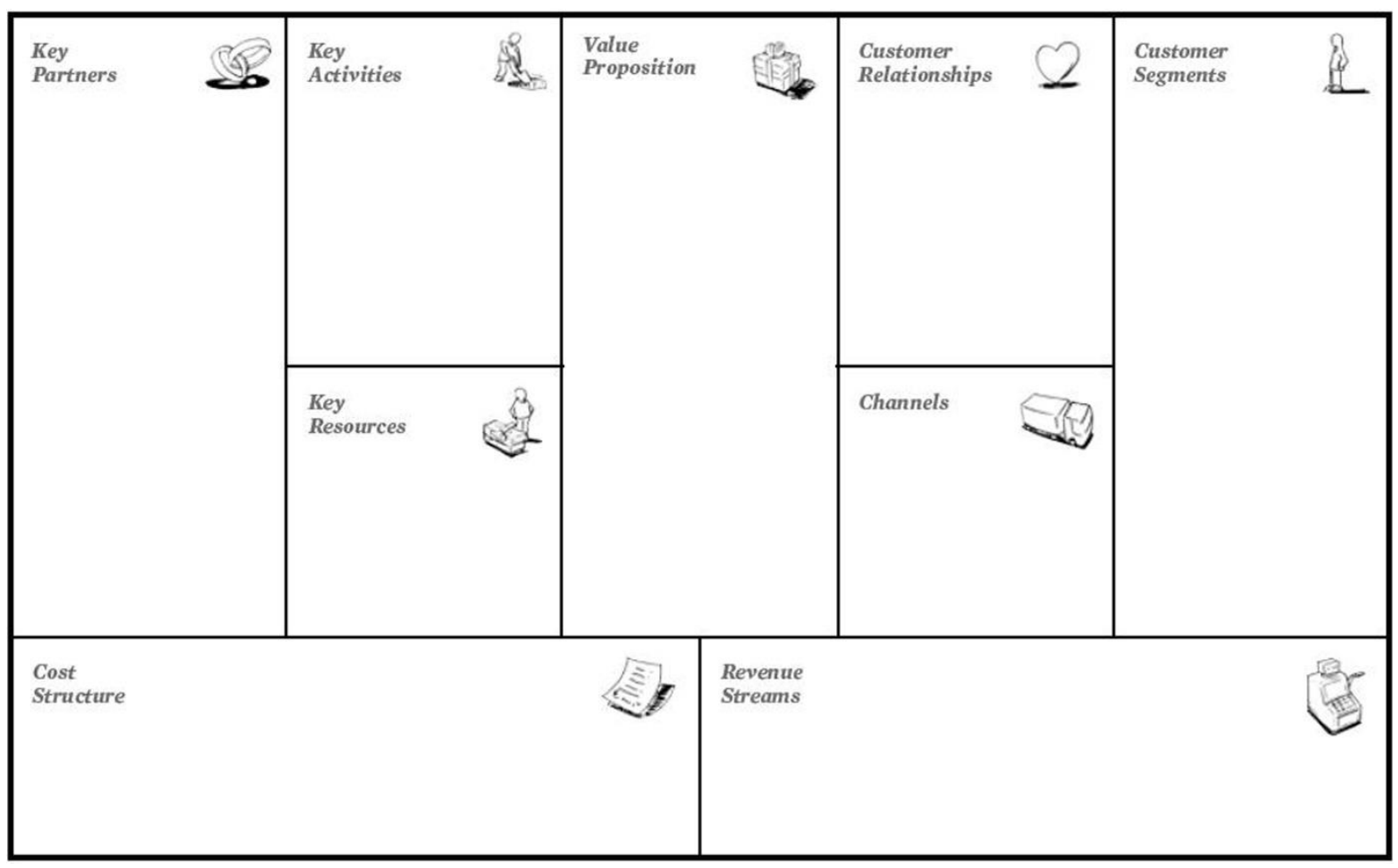

Figure 5: Business Model Canvas

\subsubsection{Value Proposition}

This section identifies the products and services the business can offer to its customers. Basically, the company's value proposition is what distinguishes itself from its competitors. 
These values can be in the form of performance, innovation, price, cost reduction, usability, accessibility and design. In general, it can provide both quantitative like price and efficacy and qualitative like customer experience values.

Ripple Media Ltd has dedicated itself to provide business value to New Zealand and global news publishers and to the news consumers.

\section{(1) Publishing Partners}

To the publishing partners, Ripple Media Ltd has dedicated itself to offer these values.

- Consumers' willingness to pay - through the survey, we identified that the consumers' willingness to pay for a bundled New Zealand publisher websites and global publisher websites increased $13 x$ the consumers' willingness to pay for a single news publisher's website. This is the foremost value proposition that Ripple Media Ltd can offer to the news publishers.

- Equitable Partnership - through the Open Business model, we can offer nonexclusive and open platform to all partners with the ability to build an equitable partnership across the competitive rivalries. This will not breach the Anti-Competitive Law under Commerce Act 1986.

- Robust and Secure Paywall solution - the product/solution that is being delivered to the news publishers will be robust, secure and seamlessly gets integrated into their current website.

- Support and Maintenance - Ripple Media Ltd will also provide the News publishers with full support and product maintenance with dedicated and skilled team. By the News publishers outsourcing their paywall solution with the added collaborative approach by Ripple Media Ltd can help them to focus on News publishing and better content delivery.

\section{(2) News Consumers}

To the newsreaders, Ripple Media Ltd will offer these values.

- Easy access to Premium content - due to the nature of the business model, the News consumers can access Premium content using our product as the channel. They can 
easily subscribe to the bundled News from New Zealand's publishers and global publishers which will add value and reduces cost and hassle paying for all the News websites under the paywall.

- Convenience - the news consumers will have convenient choices to subscribe to either a single news website that they like or to a bundled New Zealand's news publishers or to a bundled global package. This gives them a flexibility to choose and pay based on their reading habits.

\subsubsection{Key Partners}

This section identifies the key partners, key suppliers and key resource acquiring partners. This helps us to have an optimised business process, improved economy, better resource management and reduces risk and uncertainty.

Our business model identified 4 key partners.

\section{(1) Publishing partners}

Ripple Media Ltd has identified two categories of publishers.

- Enterprise Publishers - These are the main publishers in NZ and the key partners of Ripple Media Ltd. Our entire Business model centers on these publishers. Along with the NZ publishers, the global news publisher like The New York Times, The Dominion Post, and The Huffington Post will also play a vital role in the business.

- Independent Journalists - these play a major role in the journalist community as they have a larger audience. These are the casual bloggers, serious bloggers or small to medium scale companies publishing articles which are targeted to the particular audience.

\section{(2) Open source partners}

Due to the open source nature of the business, Ripple Media Ltd has identified the key open source partners who can help and develop the business.

- Knight Foundation News Challenge - an open source media accelerator helping the media companies through a platform built on OI Engine which collaborates and provides an open discussion. 
- Knight-Mozilla Open News - another open source global network of journalists, developers and hackers collaborating on innovative tools that can help the journalism thrive on the open web.

- Catalyst IT - largest open source service providers in New Zealand who can help Ripple Media Ltd by providing tools and services.

- PIWIK - largest open source web analytics software that will help Ripple Media Ltd in getting detailed insights on consumers' usage in the news partnered websites.

\section{(3) Promotional and Sales partners}

With larger promotional and sales partners, this will increase the reputation of Ripple Media Ltd of the larger consumers. This will help the company to grow externally and build a trusting relationship between the partners.

- Publishers - the small scale to medium scale publishers who can become the potential partners.

- Providers of Complementary Media Contents - these are the media providers of music streaming and TV streaming like Netflix and Sky - these are the largest media companies both global and national with some potential to be the partners.

- ISPs - Internet Service Providers in New Zealand like Spark NZ, Vodafone NZ, Orcon NZ - although a small niche in our business development, but nevertheless they will help grow the reputation of the company in the future.

- Discount Partners - companies like Groupon, TradeMe also being another small niche can become the future partners.

\section{(4) Payment Infrastructure}

To process the payments between the consumers and the publishers, some companies provide payment processing through different mediums. Ripple Media Ltd will partner these companies for a better and seamless payment platform.

- Credit Card payment gateways - these are the companies that authorizes the credit card payments for e-commerce and online retailers. Ripple Media Ltd has 
identified Payment Express and eWAY and will seek out to one who can provide a seamless and viable solution. The goal was to find a quicker and inexpensive monthly rates rather than pay-per-transaction packages.

- PayPal - One of the leading international digital wallet based e-commerce business, allowing money transfers and payments to be made through internet. The money transfer / payments can be made by an existing PayPal user or through a credit card which allows a wider payment option for the consumers.

- Banks - this is an easy and secured way of transferring money. MoneyGram (MoneyGram, n.d.), a USA based company that allows a seamless transfer from bank account to bank account. This allows the consumers to instantly transfer money to Ripple Media Ltd without the trouble of entering the bank account number and reference code. The user simply selects bank transfer and MoneyGram takes care of including Ripple Media Ltd bank account number and appropriate reference code to identify the consumer.

\subsubsection{Key Activities}

This section identifies the key activities in executing the value proposition of the company. These activities will help improve and maintain a strong relationship between the key partners.

\section{(1) Market Research}

An important component of any business is to effortlessly gather information on target markets and customers. Ripple Media Ltd has spent and will spend extensively in identifying a better value proposition to both publishers and consumers. The survey, conducted by the team was one of the key steps in market research which identified our goals, customers and value proposition to these customers.

\section{(2) Customer Acquisition}

Our two main customers being the publishers and consumers, Ripple Media Ltd strategized ways to acquiring these customers. Some of the steps involved conducting business meetings with the publishers and gaining their consent and building their confidence in our value proposition. 


\section{(3) Platform Development}

The next practical step after market research is to work on the solution. The product developed by Ripple Media Ltd was built using various technologies and tools which provided a simple and viable product that both the publishers and consumers can use.

\section{(4) Collection and Distribution of Royalty Pool}

This being a vital activity, Ripple Media Ltd ensured the royalty distribution is fair and is based on numerous factors. Currently, nothing has been finalised with the royalty distribution, but in the future, the team will seek out to the experienced advisors who can guide through subtle factors and decide on the protocol for royalty distribution.

\section{(5) Customer Support and Maintenance}

After the product is launched, Ripple Media Ltd will maintain a dedicated team who can provide support to both the publishers and consumers and also technical team for enhancing and maintaining the product.

\subsubsection{Key Resources}

This section identifies the key resources that are needed to create a value to both the customer - publishers and consumers. The resources that were identified can be under the intellectual, financial and human category.

\section{(1) Ripple Media Team}

This is a main and vital resource to Ripple Media Ltd. The team needed a dedicated person or a team to manage the business aspect, product development aspect and also the production and maintenance phase. The recruitment was mainly through a general interview and / or recommendation by a friend or family. During the development phase, Paul Smith, an open source developer from New Plymouth, New Zealand (who is not part of the Masters of Advanced Technology Enterprise) has joined Ripple Media Ltd. He showed interested in the project and was also looking for methods to improve the way the news was funded. Interesting fact was that he got to know about the project after taking the online survey that was forwarded by his friend. He contacted Ripple Media Ltd and extended his offer to work for the company. 
(2) Research Findings

This was another key resource that resulted after the market research. The findings were mainly through the survey that was conducted by the company.

(3) Ripple Platform and Technical Infrastructure

The Ripple platform was manifested in the form of a software which will be elaborately discussed in the later chapters. Along with the software, the resource was the infrastructure for hosting the software.

\section{(4) Publishing Partners}

Nevertheless, the publishing partners are themselves the key resource to Ripple Media Ltd.

(5) Open Source Partners

These are not only Ripple Media Ltd key partners, but also the key resources.

(6) Finance

The funds were mainly through the first stage investors (also known as seed money). In the company's early stages, the expenditures were taken from the savings of the individual members of the company. In January 2015, the company approached Lightning Lab, a New Zealand based start-up accelerator owned by The Creative HQ, New Zealand for support on finance and mentorship.

\section{(7) University Networks}

These are the people in Victoria University of Wellington, who referred the company to the publishers and other corporates for discussing the company's solution to the current problem in the news industries.

\section{(8) Registered Users and Paying Subscribers}

These will be our foremost and largest resources who can provide us with the valuable information on improving the system after it has been launched.

\subsubsection{Customer Segments}

This section identifies the customers the company is trying to serve. Ripple Media Ltd has identified two customers that will be served through our product and service. 


\section{(1) News Publishers}

The focus will mainly be on the two major news publishers in New Zealand and the global publishers like New York Times and The Economists. Along with these major news publishers, independent journalist will be included as our customer segment.

\section{(2) News Consumers}

Nevertheless, the news consumers ranging from young to old, male and female, casual to serious news readers will be targeted.

\subsubsection{Customer Relationships}

This sections identifies the relationship the company has to its customers to ensure the survival and success of the business. This can be identified as different services like assistance, automated services or dedicated services that are provided to the customers. Ripple Media Ltd will have different relationship between the news publishers and customers. They are:

\section{(1) News Publishers}

In order to maintain a collaborative and successful relationship with the news publishers, Ripple Media Ltd will provide these services to the news publishers.

- Technical assistance - this is the assistance in the product that is delivered to the news publishers.

- Content analytics - Ripple Media Ltd will provide a dedicated dashboard to each of the publishers for getting insights on their content like the popular articles, favourite articles / categories and so on.

- Royalty Distribution - the royalty will be distributed based on open and fair usage.

(2) News Consumers

In order to grow in the business, Ripple Media Ltd will provide these services to the news consumers.

- Customer Support - a dedicated team to provide 24/7 support to the news consumers regarding the product usage and payments.

- Access to various partner news websites - an easy access to all the partner websites will be provided based on the consumers' subscription package. 


\subsubsection{Channels}

This section identifies different channels that are fast, efficient and cost effective ways to deliver the company's value proposition to the customers. Ripple Media Ltd has identified few channels for acquiring the news publishers and news consumers trust.

\section{(1) Publishers Acquisition}

The main channel that is used to deliver the publishers' value proposition is through the media coverage. Articles were published in Nation Business Review and New Zealand Herald (see references section) briefing about the survey and how Ripple Media Ltd aims to provide a viable solution to the ways the news are funded. Radio New Zealand also interviewed one of the team members who gave insights to the news funding and its potential to change the ways the news are funded.

\section{(2) Consumers Acquisition}

The main channel that will be used to deliver the consumers' value proposition is through the partner websites as the product will be delivered through them.

\subsubsection{Cost Structure}

This section identifies the costs inherent in the business model. Ripple Media Ltd has acknowledged the costs involving developing, testing and maintaining the system along with the administrative costs.

\subsubsection{Revenue Stream}

This section identifies the money flowing in, within and out of the company. Ripple Media Ltd source of revenue is by news consumers subscribing to the news packages. 


\section{Product Development}

After consolidating the requirements discussed in the previous chapter, the team focused on building the product using various technologies. In the beginning and due to the nature of the business, a prototype was built to showcase it to the potential customers, investors, mentors and business partners. Then the prototype was manifested in different stages when the functional and non-functional requirements were considered.

\subsection{Requirements}

The initial prototype was built based on the assumptions the team had on how and what the product supposed to do. Through reviews and feedbacks, the prototype was enhanced and improved which meets the business customers' requirements.

\subsubsection{Functional Requirements}

In the software industry, the functional requirements are the set of functions the software delivers by accepting set of inputs, the behaviour and outputs (Wikipedia, n.d.). The Ripple Media Ltd team is focusing on meeting these functional requirements that were gathered from the potential customer, investor, mentors and business partners.

1. When a non-signed-in user / anonymous user accesses the publishers news website, the publisher allows a certain number of free articles that the user can view which can be reset either daily, weekly or monthly.

2. When the number of free articles limit exceeds, the user may not interact with the publisher's news website.

3. The Presspass application will provide a basic authentication. It will also provide single sign-on authentication using social media network website.

4. Signed-in user can subscribe to different packages - per site, national package or global package.

5. The user can pay for the subscription using different payment options - PayPal, Credit card and direct bank deposit.

6. The application should collect the user's web usage data.

7. The publishers will have a dashboard that will display the trends among the news readers. 


\subsubsection{Non-functional Requirements}

In the software engineering world, the non-functional requirements, identifies the principles that judges the operation of the system rather than the specific behaviour of the system (Wikipedia, n.d.). Ripple Media Ltd has 4 main non-functional requirements that the team focused on to deliver it to the customers. They are:

1. Seamless integration - for the publishers, Ripple Media Ltd decided to provide a solution in the form of a web widget that gets easily integrated into their existing news website. The lesser the publishers' IT team spends on enabling Presspass system on their existing news website, the more they would consider on using the system as a viable paywall system.

2. Lightweight - The system should consume minimum resources in terms of bandwidth, storage and processing time on the client machine, publishers' server machines and in the Presspass server machine.

3. Scalable - The system should be able to scale to larger news consumers globally. Also, the system should be able to accommodate multiple news publishers who will agree to become Ripple Media Ltd partners.

4. Reliable - Since the system will be involved in processing payments using credit cards, the system is expected to handle unexpected errors or faults. The system should be able to serve large requests without interruptions and delays.

\section{$4.2 \mathrm{UI}$}

The team dedicated considerable time on designing the User Interface for both the news consumers and the news publishers. The main considerations were simplicity and adequateness while designing the user interface.

\subsubsection{News Publishers}

Every news publisher partnered with Ripple Media Ltd will be provided with a dashboard that gives insights of the web usage of users using their news website. This information will help them to understand the common trends and usage. 
PIWIK is a large, open source web analytics software in the world (PIWIK, n.d.). Every Ripple Media Ltd partnered news publisher's website will be enabled with PIWIK that collects data from the client side which will give insights of articles read and the time spent by the user on that article. Through PIWIK, the partnered news publishers will receive a customisable dashboard.

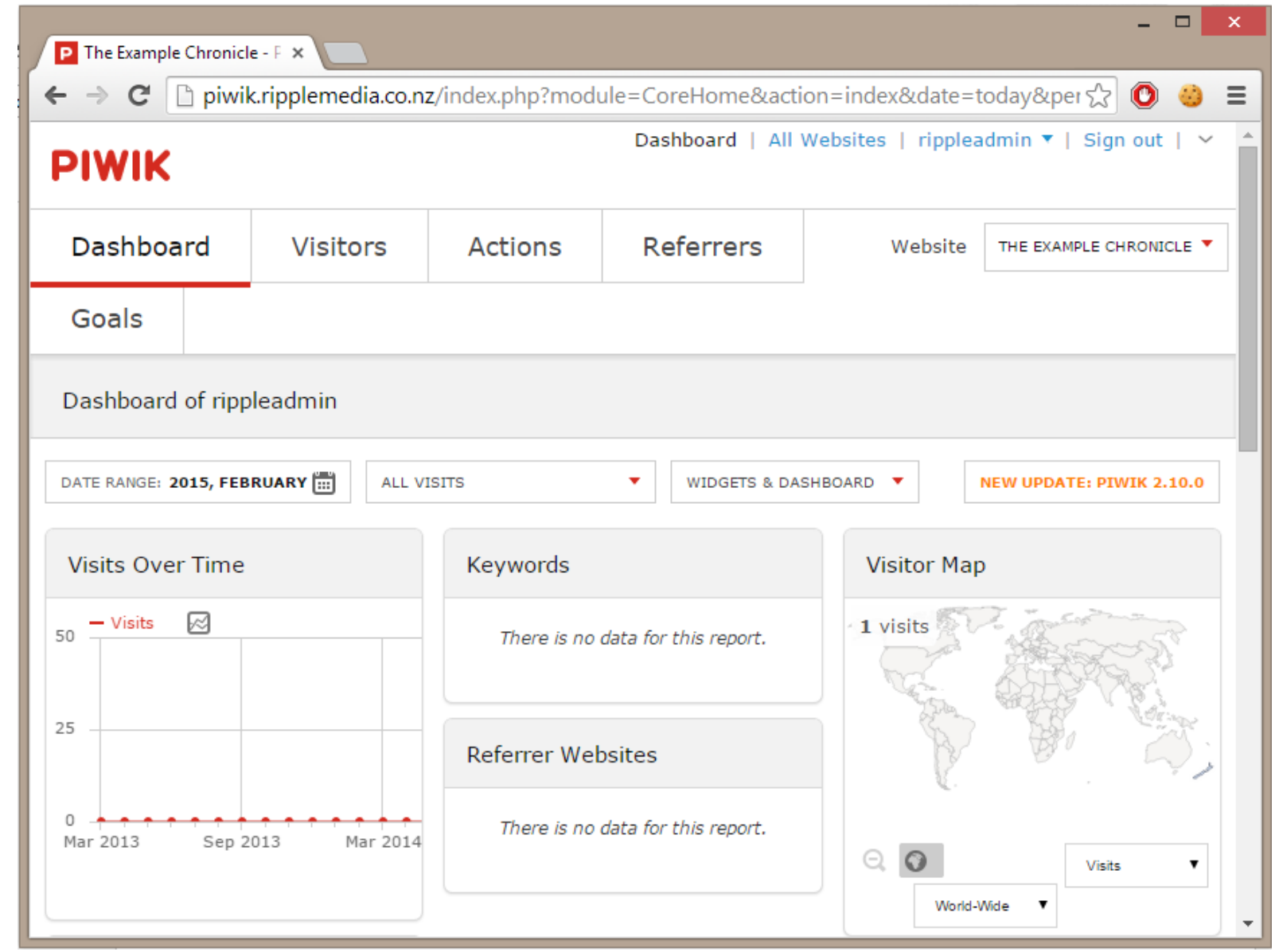

Figure 6: PIWIK dashboard

The above image is a screenshot of the PIWIK dashboard that is viewed by the news publishers. The news publishers can customize their dashboard by including multiple widgets to get user insights. Ripple Media Ltd recommends two widgets to the news publishers that will help them understand the web usage within the context of funds sharing. Since the factors used for sharing the funds across the partner news publishers are the number of articles viewed by a user and time spent on each article, the Visitor Widget of PIWIK gives 
this information which will determine how much the news publisher will receive in terms of funds.

\subsubsection{News Consumers}

The Presspass system is a web widget that gets appended to the partnered news publisher's website. It is a simple ribbon that is visible on top of the webpage. The amazing fact about this ribbon is that the Ripple Media Ltd team focused on revamping its user interface design to achieve a design that is simple and sleek as it can be used by users belonging to different ages, gender and computer literacy.

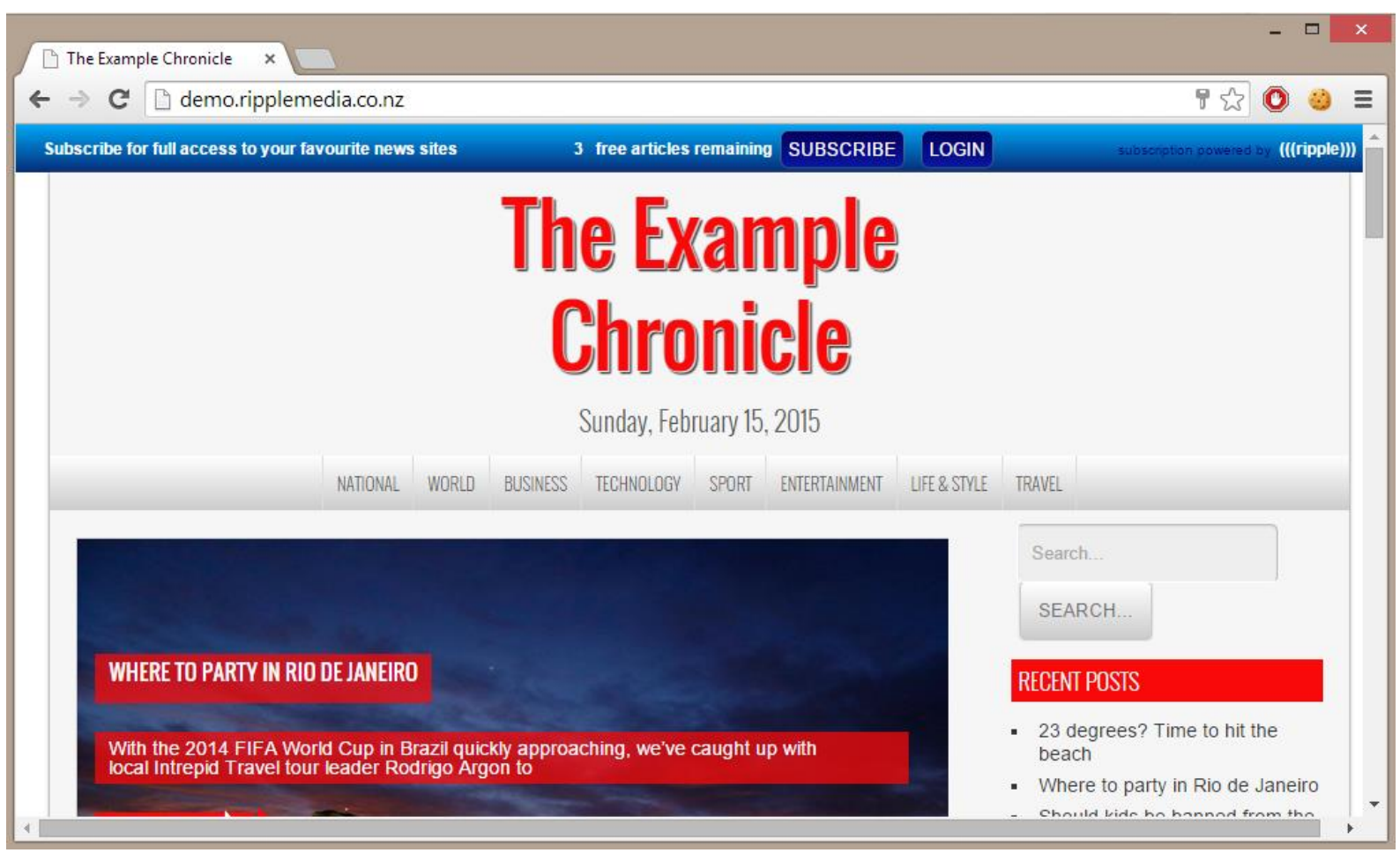

Figure 7: Presspass ribbon on demo site

The above image is the screenshot of a demo site that was used by the team along with the Presspass ribbon that is prepended onto the website. The blue ribbon is the Presspass system and anything below is the actual content of the news publishers. The below image illustrates how an actual news publishers website will look before and after the Presspass ribbon is enabled. 


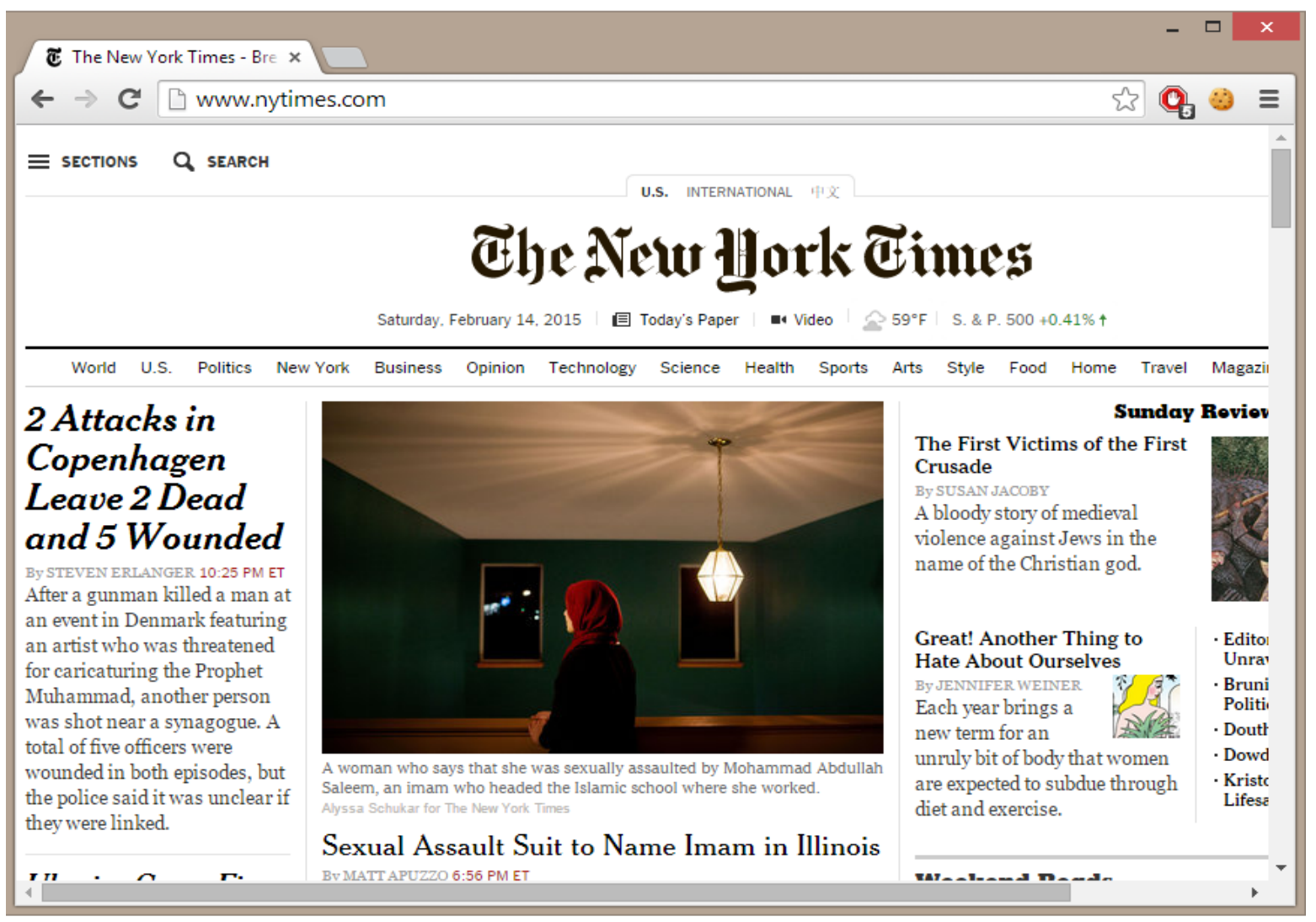

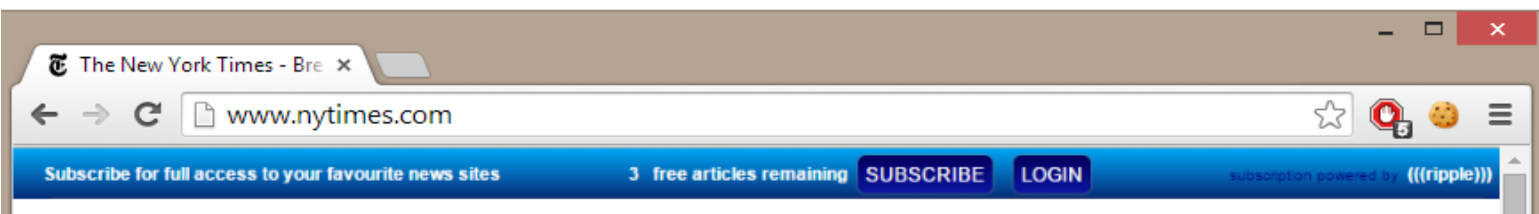

E SECTIONS Q SEARCH

\section{Elbe New lyork Times}

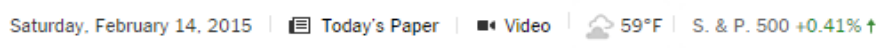

World U.S. Politics New York Business Opinion Technology Science Health Sports Arts Style Food Home Travel Magazil

\section{Attacks in}

\section{Copenhagen}

Leave 2 Dead and 5 Wounded

BY STEVEN ERLANGER 10:25 PM ET After a gunman killed a man at an event in Denmark featuring an artist who was threatened for caricaturing the Prophet Muhammad, another person was shot near a synagogue. A total of five officers were wounded in both episodes, but the police said it was unclear if thev were linked.

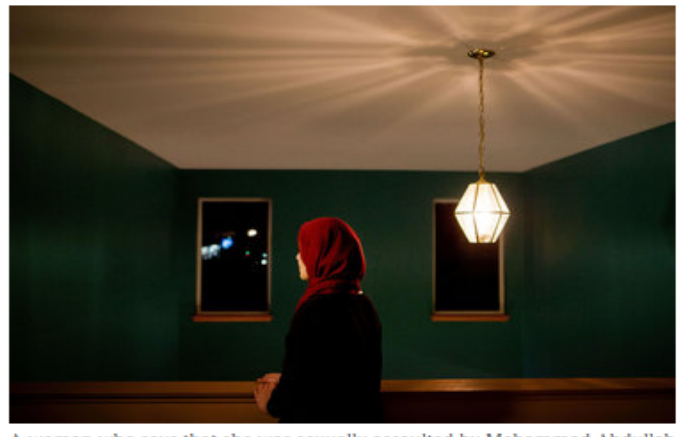

A woman who says that she was sexually assaulted by Mohammad Abdulla Saleem, an imam who headed the Islamic school where she worked.

Sunday Roviov

The First Victims of the First Crusade

By SUSAN JACOBY

A bloody story of medieval violence against Jews in the name of the Christian god.

Great! Another Thing to Hate About Ourselves

BY JENNIFER WEINER

Each year brings a new term for an are expected to subdue through diet and exercise.

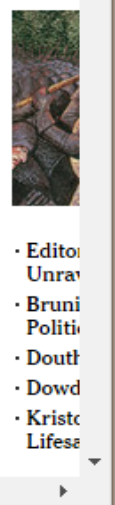


The ribbon is divided into 3 segments.

i. The information segment, which is seen on the left, displays active information to the user. The upcoming version of Presspass will provide useful information such as related articles, News Flash, more on the current article from the other Ripple Media Ltd partnered websites.

ii. The action segment, which is seen on the middle, provides basic actions that the user can perform - Login, Subscribe and Logout (if the user has logged in). If the user has not logged in, it shows the number of free articles remaining.

iii. The Ripple Media Ltd logo segment, which is seen on the right, displays the logo of the Presspass ribbon belonging to Ripple Media Ltd.

(1) Anonymous User

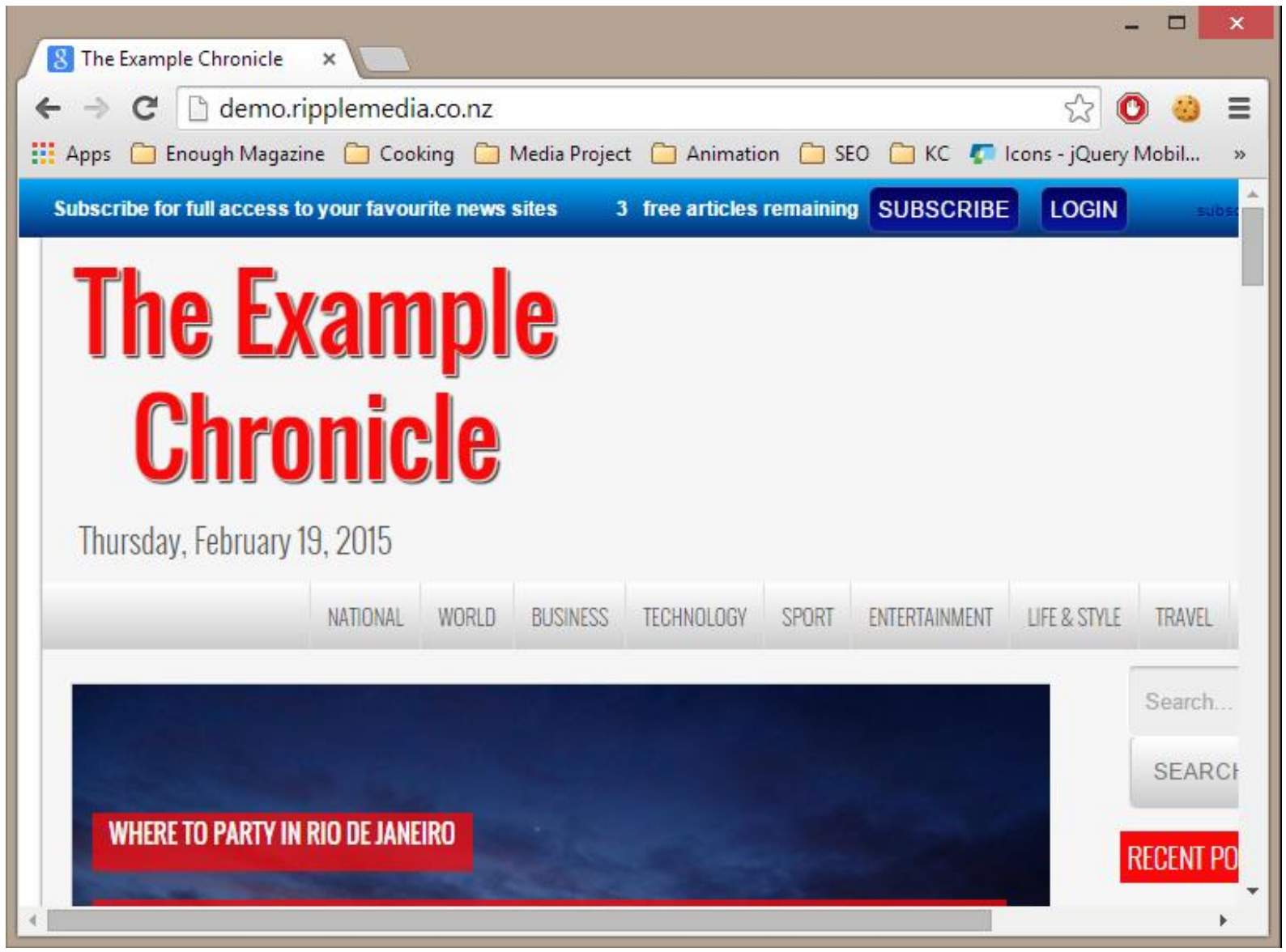

Figure 9: Anonymous User before viewing an article 
If the user was not logged into the Presspass system previously, the system will identify his as an anonymous user. Every anonymous user will receive certain number of free articles either daily, weekly or monthly. The available number of free articles for that user is viewable on the action segment.

From the above image, the anonymous user has 3 free articles. When he views an article, the counter is decrement by one as seen below.

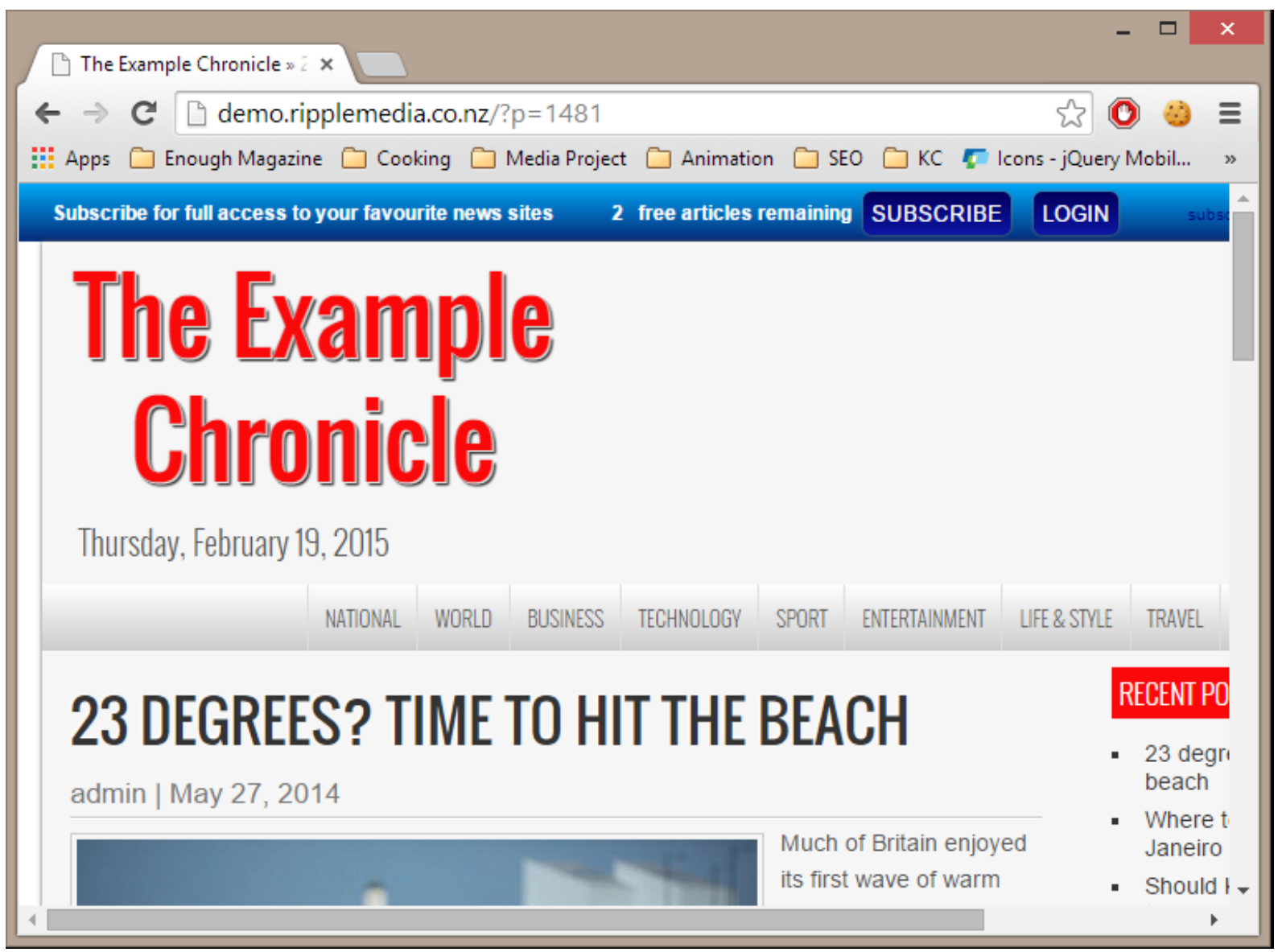

Figure 10: Anonymous User after viewing an article

\section{(2) Subscribe}

From the action segment, the user can subscribe to the Presspass system. When the user clicks on the Subscribe button, a popup will appear which navigates the user to different stages of subscription process. 


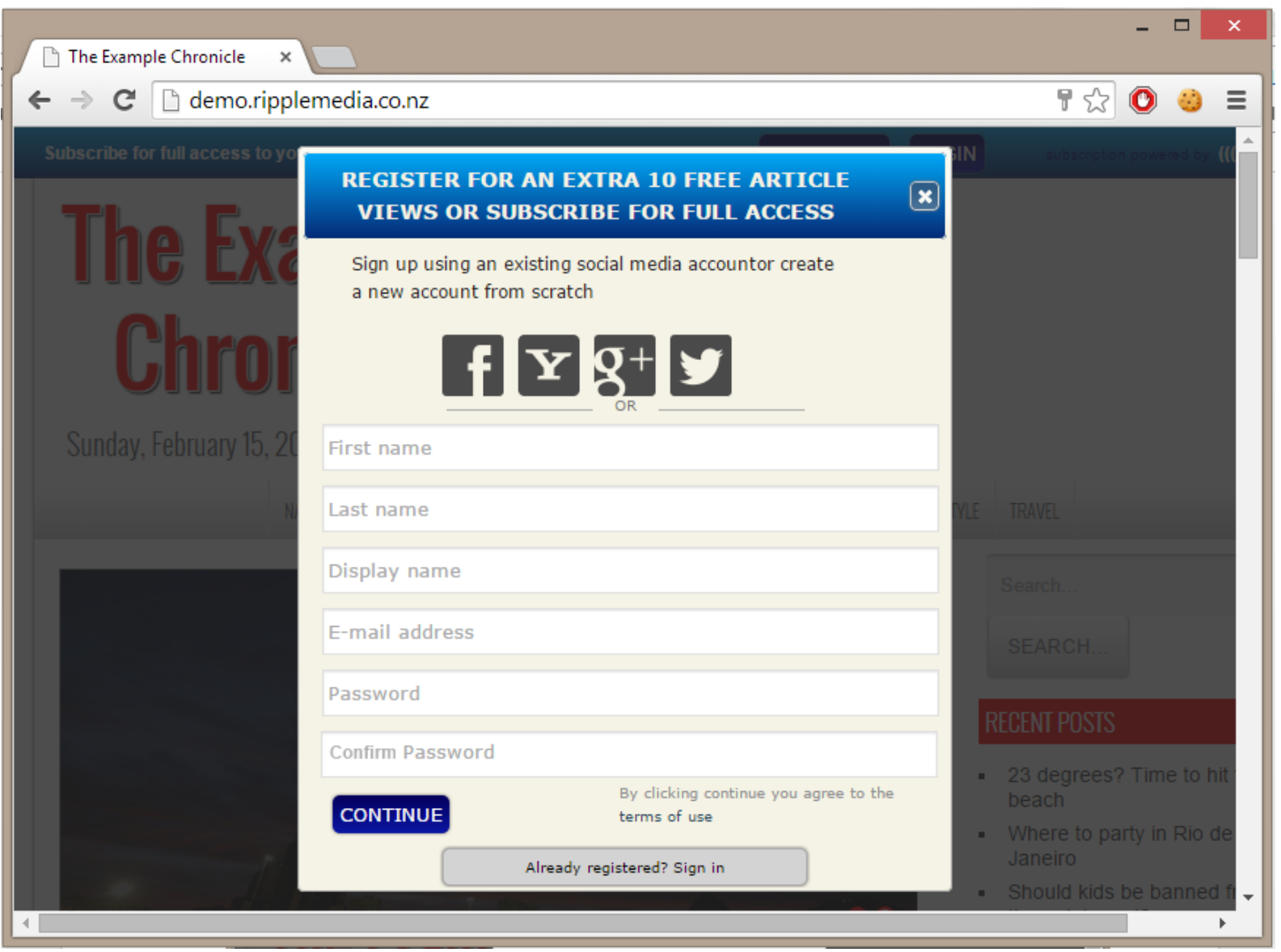

Figure 11: Step 1 of subscription process

The first step in the subscription process involves a user registering to the Presspass system. The user can either use single sign-on with the existing social media network websites (Facebook, Yahoo, Google Plus or Twitter) for registering to Presspass or they can create an account by providing their Name, Email address and password. If the user decides to use social media network single sign-on, the respecting social media network sites will handle the login request. After the user has successful logged into the social media network website or the user fills out the registration form, the user should click on the Continue button to enter the second step of the subscription process. 


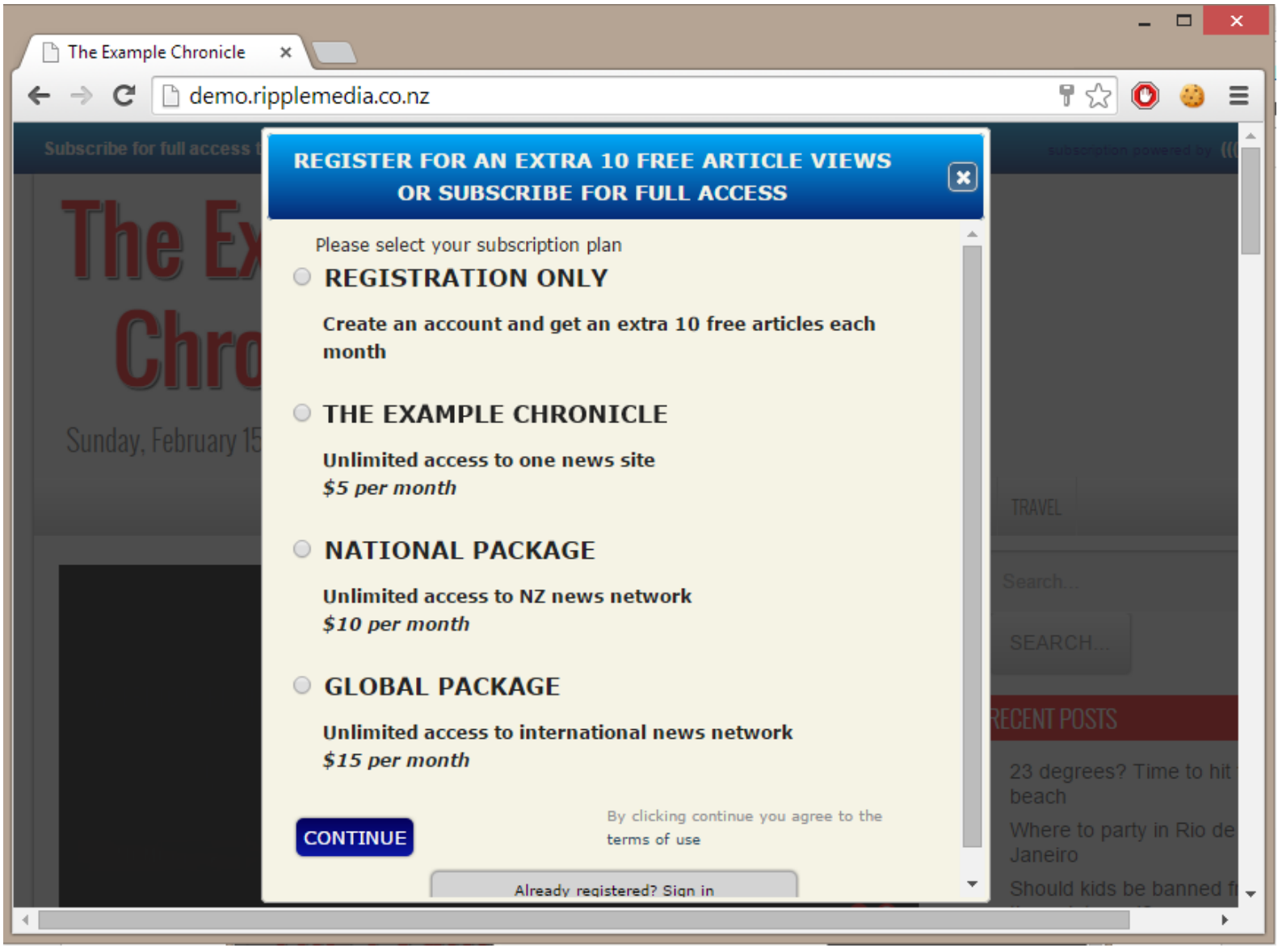

Figure 12: Step 2 of subscription process

In the second step of the subscription process, the user is prompted to select the different subscription packages -

i. Registration only - By simply registering into the Presspass system, the user can receive certain number of free articles daily, weekly or monthly. This will attract the users and also gives us a better insights to user's web usage.

ii. Single website only - In this case (above image), it is the demo site, The Example Chronicle that the user can subscribe. The user will receive unlimited access to a particular news website the user subscribe for.

iii. National Package - the user can gain unlimited access to all the New Zealand's news publishers' website that are packaged as a single bundle.

iv. Global Package - the user gains unlimited access to all the New Zealand's news publishers' website and global publishers who are partnered with Ripple Media Ltd. 
The user can select one of the subscription packages and continues to the third and final step of selecting a payment method.

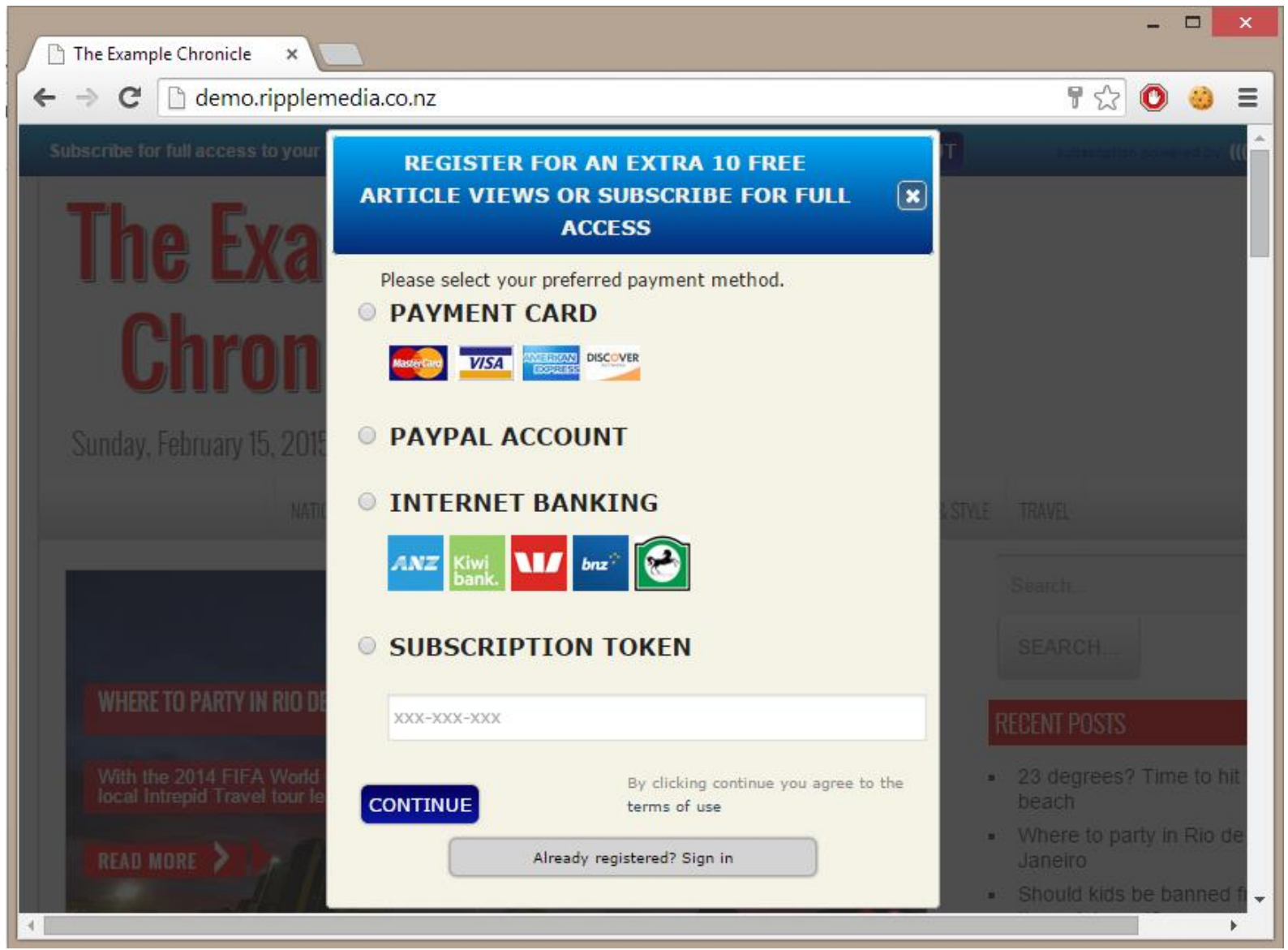

Figure 13: Step 3 of subscription process

In the third step to the subscription process, the user can select different payment options that a user and pay for the subscription. The different options are -

i. Payment card - these are the different payment cards such as master, visa card. To process, authorise payments using these cards, Ripple Media Ltd will partner with payment gateway providers in New Zealand who can provide a reasonable transaction fee, reliable and fast transactions of credit and debit cards.

ii. PayPal - although a not so widely used among the New Zealanders, PayPal process credit card payments quickly and with reasonable transaction fee.

iii. Internet Banking - here, the news consumers can pay as a bill to Ripple Media Ltd online. For a more secured and making a transaction with valid reference code, MoneyGram (MoneyGram, n.d.) will be used by Ripple Media Ltd. 
iv. Subscription Token - these are the token, coupon code that a user would receive during promotions.

(3) Login

From the action segment, the user can login to the Presspass system. When the user clicks on the login button, a popup will appear asking the user to use an existing social media network account that was already registered with Presspass system or by using a registered email and password (the user registers to Presspass through the first step of subscription form).

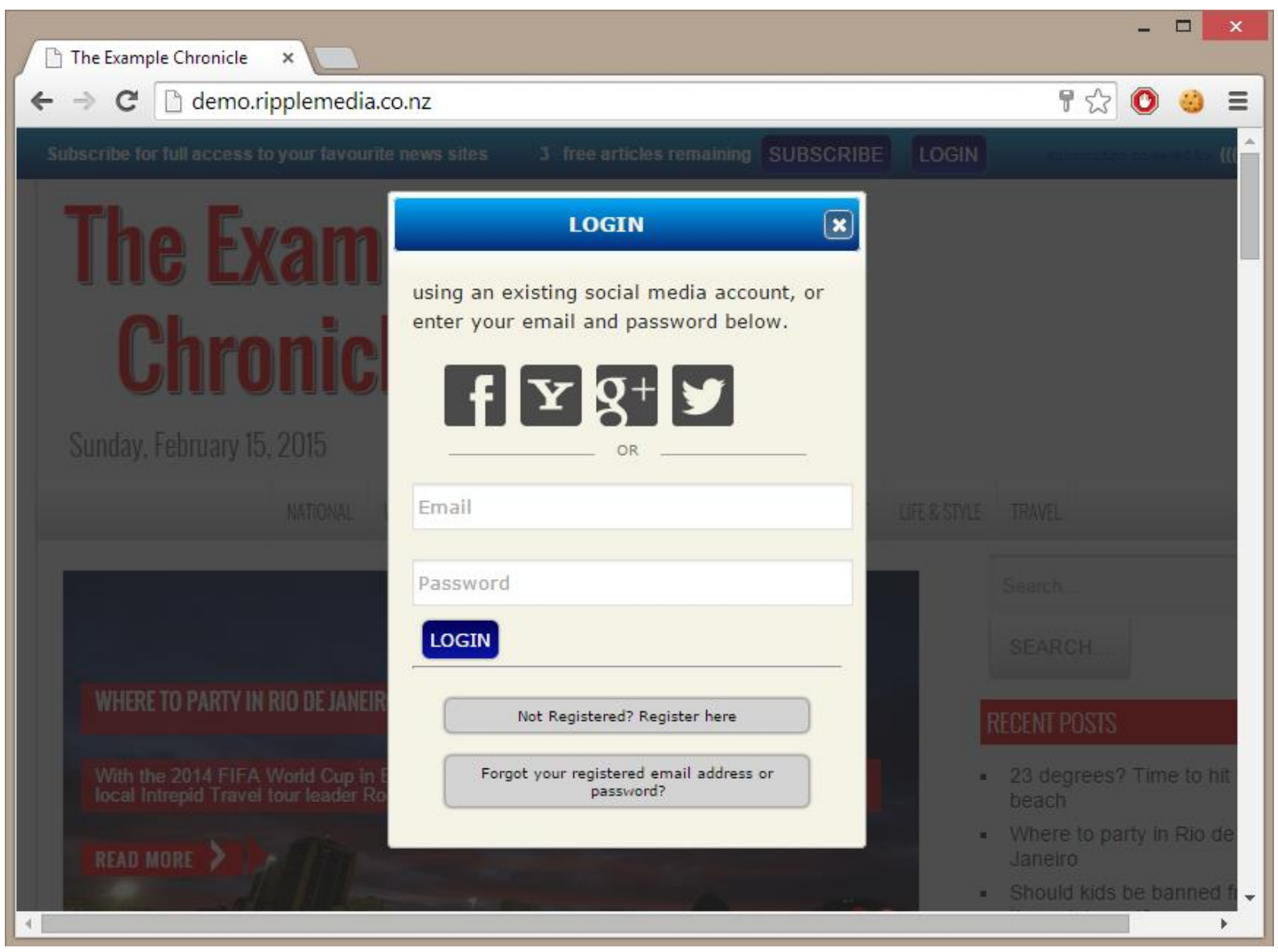

Figure 14: The login form

One of the features of the login functionality is that, if the user has logged in to the Presspass system through one of the partnered news publisher's website, they are automatically logged in to the Presspass system when they access other partnered news publisher's website (provided they have subscribed to National or Global package). This 
functionality was achieved by the Ripple Media Ltd product development team who built a cross-domain-storage access module that would allow us to store and access data through cross-domain.

\section{(4) Logout}

After the user has successfully logged into the Presspass system, the user can securely log off from the system. If the user has logged in using the social media network single sign-on, the logout functionality will not log them off from the social media network website, rather they will be logged off from the Presspass system.

\subsection{Methodology}

In order to meet the requirements of the customers, the product development will undergo different stages of life cycle. These stages of life cycle in the software industry is coined as Software Development Methodology. Many models have been developed that would achieve different required objectives. These models postulate the different stages of the process and the order in which they are executed.

The choice of the model not only specify the development process, but also the testing methods used to validate the software. These include the techniques, process, tools and types of testing which will determine the overall methodology used for developing the software.

\subsubsection{Agile Methodology}

In early February 2001, group of Software Engineers and Developers brainstormed on developing a lightweight software development methodology. They published The Manifesto of Agile Software Development (Agile Manifesto, n.d.). The manifesto states 4 values to the methodology.

1. Individuals and interactions over processes and tools

2. Working software over comprehensive documentation

3. Customer collaboration over contract negotiation

4. Responding to change over following a plan 
While acknowledging the values in the items on the right, there is more value in the items on the left. The purport to these 4 values are:

\section{(1) Individuals and Interactions over processes and tools}

The first core value of the manifesto of agile software development is to prioritise the individual and interactions between them over the processes and tools used to develop a software. The emphasis on an individual's knowledge, skills, innovation and ability to solve problems along with good communication and relationship among the team members can increase the development productivity. Having a good communication does not imply that the team holds frequent meeting, but to exhibit several key behaviours like respecting every team members' ideas, trusting the interaction, transparency over data, decisions, actions and most importantly all the individuals focusing and committing to the team's goal. This means that the individual should be self-motivated, self-organised and bears responsibility of developing a product.

(2) Working software over comprehensive documentation

This value actually measures the progress of the software product development. On a set interval, the agile team presents a working software on a progressive path to its customers. Firstly, the agile team must define what the "working software" means, which is frequently referred to as the definition of done. A piece of functionality or feature at the very least should be developed, tested, integrated, and documented before presenting the "working software" to the customers.

Traditionally, when a project is said to be 60 percent done and the team doesn't have any working software, 60 percent traditionally mean 60 percent in progress and 0 percent done. However, in an agile project, the 60 percent done means the product has 60 percent of working product features mentioned in the requirements document.

The team will focus on developing and delivering the product rather than focusing on extensive documentation. However, in an agile project, the team focuses on having a requirements document that details out all the necessary features and functionalities to be delivered and a product technical specification which documents the product features for future enhancements. 


\section{(3) Customer collaboration over contract negotiation}

The third value of the agile manifesto emphasizes on involving the customers throughout the product development who can provide valuable feedbacks and future enhancements. The customer would receive frequent deliverables from the team and in turn would provide feedbacks on a progressive product development, eliminating the unnecessary negotiation with the customers and building a stronger customer relationship. Traditionally, the customers were generally involved in 3 stages of product development - project starts, any changes and end of the project. Agile advices to involve the customers on the daily basis that industry data show the projects have a higher success rate than using the traditional method of product development.

\section{(4) Responding to change over following a plan}

The fourth value of the agile manifesto advices the team to respond to the changes rather than following a strict plan. This does not mean that the product development team does not lay out a strategic process, but, they should have an inbuilt process that would accommodate changes in the plan. Although these changes look very dynamic, the agile projects accommodate these changes strategically and systematically. Traditionally, while the customers received the final product with all the features implemented, often the customers are unhappy with their product. Generally the customers are unsure of what the product should do until they actually receive the working software as mentioned by the Humphrey's law (Capers Jones, 2014) (Noel, 2013). In the agile development, the customer can unfold various features the software can perform and due to its flexibility, the customers are generally satisfied with the outcome of the product.

\subsubsection{Extreme Programming}

Extreme Programming is a type of agile methodology intended to improve the quality of the software along with the changing customer requirements. There are many rules and practices followed in extreme programming (The Rules of Extreme Programming, 2015) however, Ripple Media Ltd.'s development team could not adapt all the rules and practices as they were meant for a larger organisation. Since the development team consisted of only two developers, practices such as small releases, code refactoring and collective code ownership were followed. 


\section{(1) Small releases}

Frequent iterative versions of the product were released to the potential partners, mentors and stakeholders who gave feedback which became the foundation of the software requirement of the succeeding version.

\section{(2) Code refactoring}

The code was refactored by peer review along with a generic coding standards, commenting standards were agreed among the development team helped in maintaining the consistency of the code for easier reading and refactoring.

\section{(3) Collective code ownership}

Collective code ownership was encouraged among the development team for contributing new ideas to all segments of the project. Any line of the code could be interchanged by the other member of the team to add functionalities making the development collectively owing the code rather than an individual's contribution.

\subsubsection{Ripple Media Ltd and Agile Methodology}

The project requirements were unclear in the initial stages of the product development. Due to the nature of the project, Ripple Media Ltd.'s product development team closely followed the agile methodology. The 4 values mentioned in the agile manifesto were considered that helped us to succeed in developing the product.

i. Individuals and their interactions - the team comprised of two software developers. I was specialised in developing the front end using HTML5, JavaScript, CSS and JQuery framework. The other developer, Paul Smith was expert in developing the server side code using PHP. Due to this unique expertise in certain fields and knowledge of the other person's field, our contribution was appreciated and valued among the customer, mentors and other members of Ripple Media Ltd. The team faced a challenge in working in the same physical location as Paul lived in New Plymouth. To bridge this communication gap, we used Trello (Trello, n.d.), a free online application that helped us to manage and assign tasks among the team members. We believe that the product development progress could have improved if the team was 
physically located in one place. The team adapted to this situation and persuaded with the product development.

ii. Delivering working software - we started developing the product with minimal requirements and very little understanding of what the product has to deliver. Over the period of time, we enhanced and added features to our initial prototype. Every time we met with our potential customers, investors, mentors, and customers, a working product was demonstrated to them. During the product presentation, we received feedbacks and constructive critics which helped us to enhance and improve the product. Besides, we also documented the product for future reference and identify potential improvements so that the product can deliver its core business value to its customers.

iii. Customer collaboration -many customers, investors, mentors and potential partners contributed by providing feedback on the working software. However, unlike the agile manifesto advising on having a daily involvement with the customers, we could only involve each of them, fortnightly (on an average). This did not hinder on our progress and the same time, meeting the above mentioned people every day wouldn't have made a remarkable difference. We believe that there was an ideal customer collaboration during the product development.

iv. Responding to changes - the product did not go through many changes nevertheless, the team incorporated features, functionalities suggested by the mentors, investors, and potential partners. The team followed a strategic plan on delivering features and functionalities after gathering the requirements of the above people.

\subsection{System Architecture Overview}

Currently the system is hosted in a cloud environment which can meet the customers need for scalability and accessibility. Below is the architecture diagram of the Presspass system which describes the different components on the server and client machine. 


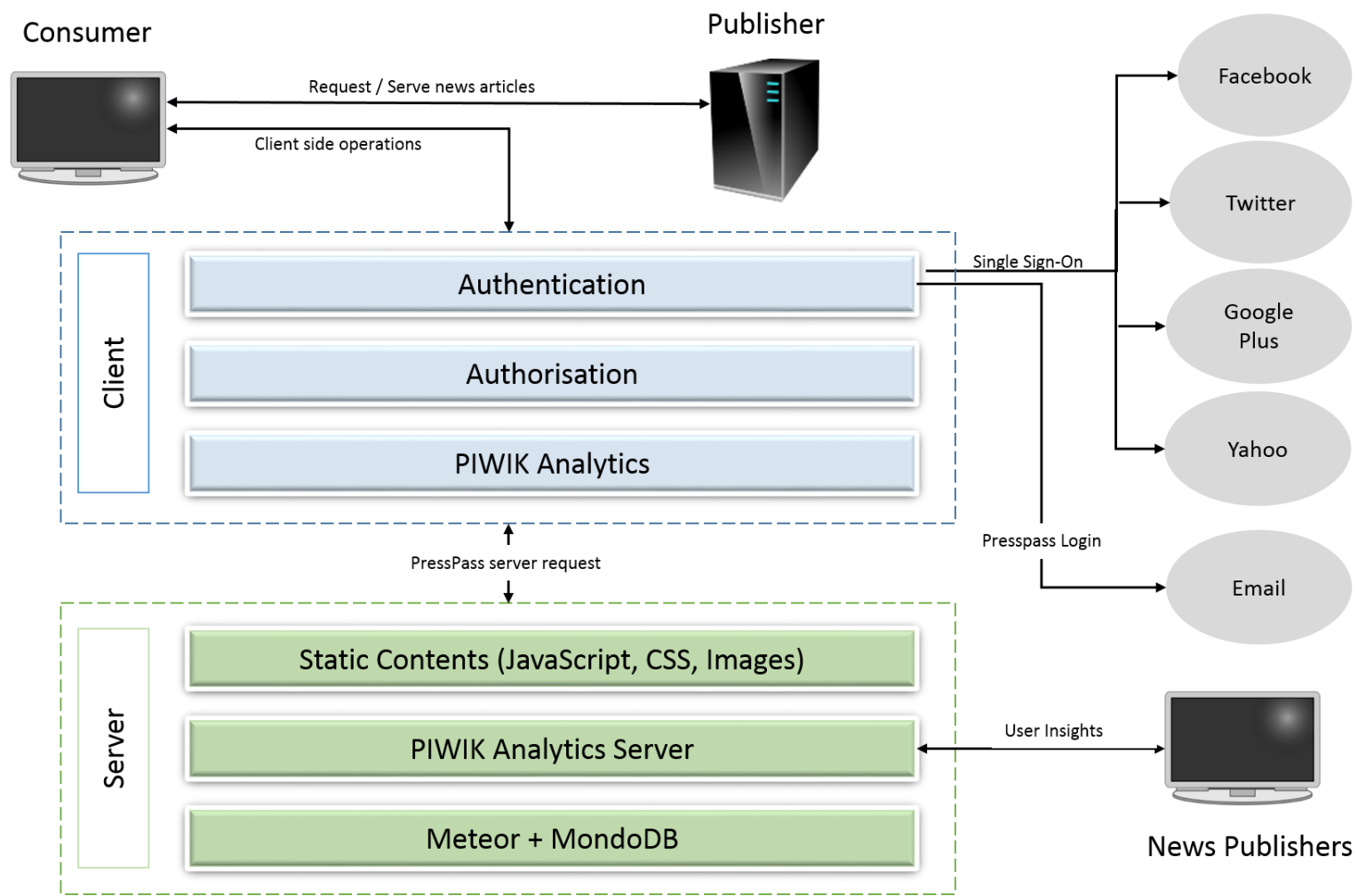

Figure 15: Architecture Diagram of Presspass

The Presspass system will operate on both server and on the client machine. As from the above diagram, there are four basic operations on the client / news consumer's machine Anonymous Authorisation, Authentication, Signed-In Authorisation and PIWIK Analytics.

\subsubsection{Anonymous Authorisation}

For any anonymous user (user that has not logged-in to Presspass) will be checked if the user is authorised to view the article. Based on Soft Paywall System as discussed earlier, users are allowed to view certain free articles before they can pay and subscribe to the news. Every Ripple Media Ltd partnered news publishers will set a default number of free articles a news consumer can read. Every time the news consumer reads a news article, the counter for free articles will decrease by 1 . When the counter reaches 0 , the news website is disabled and checks the user from interacting with the website. However, the user is prompted to subscribe to the Presspass to unlock news based on user's subscription package. 


\subsubsection{Authentication}

There are two ways to authenticate with the Presspass system - Single sign-on to social media network sites and dedicated Presspass authentication using the Username (email) and password.

The traditional login is implemented in Presspass system to accommodate consumers who wish not to use social media network single sign-on or who do not own a profile in any of the three social media network websites. This is a basic user registration / login to Presspass system.

\subsubsection{Signed-In Authorisation}

After the user is authenticated, the Presspass system will check if the user is authorised to view the article based on subscription package. For example, if a user has subscribed for a single news publisher's website then this component denies authorization to the user if they try and access other news publisher's website.

\subsubsection{PIWIK Analytics}

Web analytics is a web tool for collecting, measuring and analysing web data for the purpose of understanding and optimizing web usage. One of the factors used for distributing funds among the Ripple Media Ltd partnered news publishers is the total number of article hits by users. In order to retrieve these usage data, web analytics are used which gathers web page usage information.

Presspass has a number of operations conducted on the server side. There are three basic operations that run on the Presspass Server - Serving Static Contents, PIWIK server and Meteor with MongoDB.

\subsubsection{Serving Static Content}

One of the main operations of the server is to deliver the static contents such as the Presspass JavaScript, Stylesheets and images to the client machine. Along with Presspass JavaScript and Stylesheets, the server can serve JQuery files. However, these JQuery files can be distributed using Content Delivery Network (CDN). CDN are servers with high bandwidth 
and low fees / free servers for delivering content over the network. For the future upgrade, the all the Presspass static contents can be delivered through CDN for better load balancing.

\subsubsection{PIWIK Server}

The PIWIK running on the client side feeds data to the PIWKI running on the server, which is used to retrieve information on web usage. The server collects and consolidates all the web usage information from client that will help determine the fund value shared among the Ripple Media Ltd news publishers and also help the news publishers get insights on clients' usage.

\subsubsection{Meteor with MongoDB}

Meteor is an open source platform for building mobile and web applications in pure JavaScript (Meteor, n.d.). It allows the developers to build applications, both on client and server side code in pure JavaScript. Due to its robustness, live updates and radically less code, Meteor provides a substantial framework for building Presspass.

MongoDB is an open source document based database (MongoDB, n.d.). It disregards the traditional table-based structural database with a JSON like document based database.

With the combination of Meteor and MongoDB, Presspass is implemented using these frameworks that exposes APIs that performs different operations which will be discussed in the later chapters.

\subsection{Product Overview}

The current product is divided into two main components - one used by the news consumers and the other used by the news publishers. Both these components were developed separately by the Ripple Media Ltd product development team.

\subsubsection{News Publishers Setup}

When a news publisher officially registers to become a Ripple Media Ltd partner, our technical team follows a two-step protocol that configures the Presspass system to grant access to the publisher's website.

The first step in this process is configuring the PIWIK to collect user's web usage data browsing the news publisher's website. This is done by entering the domain name of the 
news publisher's website to PIWIK and gets registered with a unique website-id that gets used in the next step.

The second step in this process is building a configuration file that is served to the news consumers when they access the partnered news publisher's website. The configuration file is stored as a JSON (JavaScript Object Notation) file with details such as the website-id from PIWIK, default number of free articles that the publishers allow to the anonymous users / unsubscribed users and a list of non-article page URLs of the website.

After the technical team has finished configuring the Presspass system, now the technical team of that particular news publisher will have to include a script tag with the src attribute referencing Presspass system's main JavaScript file in the head section of their website. This file contains the core functionality for enabling the Presspass ribbon on the news publisher's website.

The overall process for setting up the Presspass enabled website is simple and consumes less time and resource to achieve the non-functional requirement, Seamless Integration.

\subsubsection{News Consumers}

When a news consumer enters one of the Ripple Media Ltd partnered news publisher's website, there are a series of events that occur before the Presspass ribbon is visible to the user. Depending on various scenarios, these events will lead to different outcomes.

\section{(1) Loading Necessary Components}

The publisher's website will have a script tag that requests the main JavaScript file for enabling the Presspass system. Once this JavaScript file is loaded, the first operation that it performs is load other necessary files and components. These are the files that are loaded sequentially:

i. JQuery v1.11.1 - the Presspass ribbon was built using JQuery framework. The first step is to check if the JQuery version 1.11.1 has already been loaded by the browser. There is a possibility that the news publishers they might be using the JQuery framework with the same version as Presspass system. To avoid any conflicts, the system will load the particular version of JQuery. 
ii. News publisher's specific configuration file - As discussed earlier, every partnered news publisher will have a specific configuration file in a JSON format. The JSON file is associated with the news publisher's domain / host name and hence, if a nonpartnered website try to access the configuration file, the server will respond with a 404 or File not found error message preventing the Presspass to load on the webpage.

iii. JQuery-ui and JQuery-ui-theme - these are the JavaScript and CSS (Cascading Style Sheet) files for loading the JQuery UI component, JQuery dialog.

iv. Cleanslate - this is an extreme CSS reset stylesheet (Cleanslate, n.d.). The CSS helps in resetting UI components to its original style. To provide a consistent look of Presspass ribbon and user interface across all the partnered websites, the cleanslate CSS is applied to the Presspass UI components so that they do not inherit the news publisher's theme.

v. Theme - the theme file is loaded that contain styles for all the Presspass ribbons UI components.

vi. PIWIK - the PIWIK is enabled on the client by first loading the PIWIK JavaScript file from the server and then immediately it gets initialised by supplying the website-id from the configuration file as a variable.

\section{(2) Initialising}

Now that the necessary files and components are loaded, the Presspass system initialises variables and components that are used in the ribbon. The components initialised for an anonymous user is different from the components initialised for a logged-in user. Before any components are initialised, the system checks if the user has logged-in or an anonymous user. To achieve this, the Presspass system checks for a cookie by the name rippleuserstatus. This cookie store user information if the user has logged-in and for an anonymous user, this cookie will not be present on the user's machine.

If the Presspass system identifies the user as an anonymous user, the system initializes these components: 
i. Buttons - the Login and Subscribe buttons are initialised and added to the action segment of the ribbon. The click event of these buttons is defined to open a JQuery dialog that displays the Login and Subscribe form respectively.

ii. Forms - the 2 forms that are associated with the Presspass system is Login form and Subscribe form. Both these forms are initialised with different UI components necessary to perform their respective functionalities.

iii. Payment - the subscribe form has merchants like PayPal, credit card and bank deposit as payment options for the users when they subscribe to the packages. Presspass system initialises the necessary SDK (Standard Development Kit) for processing the payments provided by the respective merchants.

iv. Social media network - if the user is anonymous, the user might login or subscribe (register) to the Presspass system in the future. As discussed earlier, the user can use their existing social media network sites to login to the Presspass system. Here, the system initialises the necessary SDK provided by the respective social media network websites for authorising the user and it is widely known as Single sign-on. Single signon (SSO) is a property of access control of multiple related, but independent software systems. With this property a user logs in once and gain access to all systems without being prompted to log in again in each of them (Wikipedia, n.d.). Basically, a user can login to a website using his social media network authentication, which will work in the background to securely authenticate the user and sharing information about the user with his consent to the website. As mentioned by Tom Fronczak in his article, Single Sign-On: Determining a Single Sign-On Solution for Your Website (Fronczak, 2011), single sign-on is a new alternative to logging in to a website. Presspass will provide single sign-on authentication using top three social media networking websites such as Facebook (Facebook OAuth, n.d.), Yahoo (Yahoo OAuth, n.d.), Twitter (Twitter OAuth, n.d.)andd Google Plus (Google OAuth, n.d.). The Presspass system provides a secured and easy implementation of single sign-on using an open protocol for authorisation, OAuth 2.0 used by all these social media network sites (OAuth, n.d.).

If the Presspass system identifies the user as a logged-in user, the system initialises the logout button with its functionality and it is added to the action segment. When the user 
clicks on the logout button, the system notifies the server about the operation to log off the user on the server and also delete the cookie by the name rippleuserstatus on the user's machine.

\section{(3) Processing}

Depending on whether the user is an anonymous user or a logged-in user, the Presspass system processes every page differently.

If the user is identified as an anonymous user by the Presspass system, these are the series of actions performed on the user's machine.

i. Authorise - since every anonymous user have a certain number of free articles either daily, weekly or monthly, here the system checks if the user has not exceeded that limit. The value is stored in the browser's local storage, an HTML5 feature. If the user is using an old browser that does not support HTML5 local storage, then the value is stored in a cookie. If the user has exceeded the limit, the Presspass system immediately prompts the user to subscribe by showing the subscribe form.

ii. Decrease the number of free articles counter - here the system goes through a checklist before decrementing the number of free articles the user can view. The valid conditions are -1 ) the page accessed by the user should be a valid article. The non-article URLs are stored in the configuration file and the system cross-refers to check if the URL is an article page. 2) Check if the user has already viewed this page. If the user has already viewed this page, then the system will not reduce the number of free articles the user can view. This can be achieved by storing the all article URLS that the user has viewed in the HTML5 local storage or cookies for older browsers that doesn't support the local storage feature. Then cross-refer with the current URL and then reduce the number of free articles counter by one if the user has not viewed this article earlier and store the URL and the new counter for future reference.

iii. Notify PIWIK server - PIWIK has been customised to achieve our functional requirements that is to get particular user's web usage data. Although the user here is an anonymous user, we can identify this user by providing a unique number. PIWIK automatically generate a unique number for every user and the PIWIK stores this 
value in a cookie for future reference. The Presspass system notifies PIWIK with this unique number and the current URL the user is viewing. Also, it records the time the user spends reading that particular article.

If the Presspass system identifies the user as a logged-in user, the system performs only three operations sequentially.

i. Depending on the user's subscription, authorise the user if he can view this article. The user can subscribe to either a single package, national package or global package and depending on these subscription packages, the user is authorised to view the page.

ii. Notify the PIWIK with the user name. As mentioned earlier, for an anonymous user the unique number associated with the user is passed to PIWIK for identifying the user. However, for a logged-in user, the Presspass system passes the user's unique ID provided by the social media network website.

iii. Register the article the user is reading. This is a very specific functionality for recording the subscribed user's web usage with more details. Currently, the development team is working on providing a user's dashboard to the users so that they can get more insights on their news reading habits. Meteor and MongoDB on the server side helps us to achieve this functionality. 


\section{Evaluation}

The current product developed by the Ripple Media Ltd development team provides a viable solution to our customers. The decisions we needed in picking out the methodology, process, tools, technology, and design patterns were debated, and based on valid inputs, the product was developed. Some features can also be enhanced or modified for providing a substantial value proposition to the customers. The Presspass system also underwent various testing both on the client side and on the server side to better evaluate the performance of the system.

\subsection{Decisions}

The resolutions of a particular methodology, tools and process were based on valid inputs overseeing the future of the product rather than an immediate and temporary solution.

\subsubsection{Build over Buy}

The very first decision as a team considered was whether to build the software or buy one. There were many pros and cons on having our own custom solution over distributing an already built product from another company like MediaPass (15Me) to New Zealand news publishers. If Ripple Media Ltd builds the product then it has the flexibility of providing custom features to the customers, however with the cost of having a dedicated team (IT team) just for building, testing and maintaining the product. If Ripple Media Ltd decided to become a Paywall provider by purchasing a solution form another company, then the team strength required to run the company would be minimal, but, it could become too much of a hassle to provide a custom solution to the customers. Since our business value is focused on providing a customer centred solution, the team considered in building a software product along with a software solution to the customers rather than becoming a Paywall provider's product distributor in New Zealand.

\subsubsection{Open source over Proprietary software}

The team debated on the various pros and cons on making our product open source over proprietary software. The main advantage of providing an open source software is its large developer community and its openness. It is a fact that matured open source software are least vulnerable to treats than a proprietary software due to large developer community 
addressing the software's bugs, issues and treats. In the future, due to the transparent nature of the open source makes it less vulnerable to treats. This also promotes a strong trusting relationship between the news publishers and the news consumers. The major drawback of making the software proprietary is to have a large development team to fulfil the demands of a growing business.

\subsubsection{Web widget over iframe}

The first prototype that was developed by the team used iframes for loading the publishers' website and a div tag to the ribbon. Although this method did give us an estimate of how the product should be given to the news consumers, it bore a few drawbacks that we eventually discarded using iframe in our software. The drawbacks were-

- The news consumers will be loading a page from the Ripple Media Ltd server. This page will have the iframe that loads the news publisher's website. Hence, the system will function has an aggregator (aggregating multiple news publishers' website under one page) rather than providing a paywall solution to the news publishers. This was against our business value and eventually altered the solution that could provide the business value to our customers.

- Every time the anonymous user reads an article, it would automatically decrement the number of free articles count by one. To achieve this, we used the iframe's onload() event that would decrement the number of free articles on every time the iframe loads. However, not all the web pages of the publishers' website are articles and there was no possible solution that we could implement to identify the URL (Uniform Resource Locator) of the iframe that is being loaded due to Cross-DomainAccess policy (W3C, n.d.).

\subsubsection{Web widget over API}

After discarding the iframe solution, the team considered providing an API (Application Program Interface) to the news publishers that would provide a complete paywall system. Basically, the news publishers will have to implement their own user interface and use the API provided by the Presspass system for authentication of the user who have registered with the Presspass system, authorisation of every news articles based on the subscription package and subscription to different packages. 
Although this solution provides a secured process, the news publishers will have to invest time, effort, human resources for implementing this solution was impractical and consequently the team had to discard this solution. This would go against one of our nonfunctional requirement to provide seamless integration of Presspass system on their website.

\subsubsection{PIWIK over Google Analytics / Google Universal Analytics}

Google Analytics and Google Universal Analytics are used by 82 million websites and with only 1.3 Million users using PIWIK (15Si), our team chooses to use PIWIK as its analytics software. Initially the development team started using Google Analytics for capturing web usage data until a new requirement of capturing a particular user's usage data. Google lacked in providing this functionality and our team looked out for a better web analytical software that can provide economical, fast, reliable and robust solution as Google Analytics does along with the flexibility to capture more data and importantly, a tool that is open source. After thorough research and reviewing PIWIK, the team decided to use it as the web analytics tool in Presspass system. The development team also had a chance to meet the founder of PIWIK in Wellington, who gave an assurance of providing the Presspass specific requirements in terms of web analytics such as capturing particular user's web usage and time spent by the user reading the article.

\subsubsection{Meteor and MongoDB over other server technologies}

Looking at the Ripple Media Ltd development team's skill set and business's strategic open source model, a substantial server side technology would have been to use PHP (PHP, n.d.) and MySQL (MySQL, n.d.). However, some of the development team members were not expertise in these open source technologies and perhaps in the future there might be resistance in using it. Looking for an alternative, the team researched on Meteor and MongoDB for building server side operations that simply used JavaScript as server language and JSON format as the database. The effort needed for learning and implementing Meteor and MongoDB on the Presspass server was minimal and also drastically increased the performance. 


\subsection{Testing}

One of the criteria for evaluating a software product is by testing the software to meet its functional and non-functional requirements. To validate the Presspass system's functionality, unit testing and integration testing was sufficient and to validate the system's non-functional requirements, integration testing was conducted.

\subsubsection{Unit Testing}

Unit testing verifies the functionality of a particular section of code. Its main purpose is to eliminate defects and bugs, and verify its function (operation).

The development team performed the unit testing every time a new requirement was build and the testing included, static code analysis and peer code review. The static code analysis was performed by using a JavaScript code analysis tool, JSLint.NET for Microsoft Visual Studio (Visual Studio Gallery, n.d.). JSLint.NET performed static code analysis and suggested the team to follow some of the best practices for writing code. The code was also peer reviewed with feedbacks based on experiences the team members had in the previous projects.

\subsubsection{Integration Testing}

Integration testing verifies the interfaces between components meeting the business requirements. By integrating one component at a time, the development team could eliminate any problems easily.

To verify both functional and non-functional requirements, integration testing was conducted on the Presspass system. Different components like Login, Subscription, Payment, notifying the PIWIK, notifying Presspass server were integrated and tested to verify the functional requirements. Integrating Presspass system to a web application was highly tested to see if the Presspass system did not hinder the UI and functionality of the web application. The main purpose was to achieve seamless integration as part of the nonfunctional requirement. This testing was conducted by creating 4 demo sites using WordPress, Joomla, DotNetNuke and SilverStripe as the CMS, integrating the Presspass system to these demo sites and then testing for any problems faced by the website or by 
Presspass. This testing has definitely eradicated the common web widget integration issue, CSS overriding where the web widget will inherit the CSS properties of the website.

\subsection{Publishing Server}

The Presspass system's major network bandwidth goes into serving the static contents such as the JavaScript, CSS and images, and very little network bandwidth is used by PIWIK. About $153 \mathrm{kbs}$ of static contents are served to the client machines by the Presspass system for every access. However, some browsers do allow caching of static contents to eliminate loading of redundant resources (Neuhaus, 2015). The current system is published on Digital Ocean (Digital Ocean, 2015), a cloud hosting service that provides very competitive pricing for its customers. Evaluating on the data sent across the server and client machine, the cloud services will either be upgraded or downgraded to meet the demands of the news consumers. If there are 500,000 unique visitors to Presspass system every day with browsers cache enabled, an estimation of 2.1TiB (Terra Bytes) of data is transferred to the news consumers monthly.

\subsection{Future Development}

Although the current system is ready to be used by the news publishers and consumers, there are many aspects of the system that can be improved, enhanced or modified. Some of these improvements are,

\subsubsection{AngularJS}

AngularJS is a JavaScript framework for building Single Page Applications (SPAs) using MVC, MVVM or MVW model. This will provide easy interaction between the View (HTML), Model (JSON) and controller (JavaScript functions). The next improvement in the coding practices was to use AngularJS that can support seamless data-binding.

\subsubsection{CDN}

Presspass system mainly transfers static content to its clients (news consumers). Due to the requirement of high bandwidth, the team is considering an alternative solution in the future by serving these static contents through CDN (Content Delivery Network) like CloudFlare (CloudFlare, 2015) who offers free CDN services with unlimited bandwidth data and high 
TECHNICAL CHALLENGES OF A LIGHTWEIGHT, SCALABLE, GLOBAL PAYWALL SYSTEM

bandwidth speed. This will eliminate the cost incurred by Ripple Media Ltd on servers for publishing the static contents. 


\section{Summary}

Ripple Media Ltd has reached its final stages of business development, before reaching out to the New Zealand news publishers for collaboratively improving the way the news is funded. The different goals of Ripple Media Ltd such as market research, strategic planning, finances, IP, development and deliverance were met and currently the company is seeking out to its customers and investors.

\subsection{Entrepreneurship}

MATE program gave an opportunity to establish Ripple Media Ltd through the entrepreneurial process of starting a business/company. The team developed the business model, gathered resources in terms of people, tools and money, planned the different stages of business development and now is fully responsible for its success or failure. An internal strife, being a most common pitfall of any start-up companies was avoided by clearly defining the team roles and their responsibilities. Frequent meetings were halted to correspond on the individual's progress and with feedback and constructive criticism, the team held its unity and harmony.

\subsection{Market Research}

The research conducted by Alex titled "Digital Commons or Digital Enclosures: The future of Online Content Distribution", gave insights into how people think content should be created, distributed and funded in a digital environment. Through market research and a survey with 457 respondents, Ripple Media Ltd has verified the user's inclination towards news monetisation strategies that could improve the ways the online contents can be distributed and funded, and also provide an alternative revenue model to the news publishers.

\subsection{Strategic Planning}

Ripple Media Ltd frequently laid out plans and strategies to develop the business and product. From the business perspective, the business model canvas was designed to make decisions for business development. From the product development perspective, the project followed the agile methodology principles for smooth running of the project and with an end result of providing a viable product to the customers. 


\subsection{Finances}

In the beginning of the MATE program, Ripple Media Ltd had a theoretical understanding of business investments that are divided into 5 levels -1 ) founder 2) fools, friends and family 3 ) venture capital 4) private equity and 5) public shares. As the project progressed, the company had practical experience of first 2 levels of investment where the investment came through the founders, family and friends. The company has started to seek venture capital funds for a smoother operation of the company.

\subsection{Intellectual Property (IP)}

The business model was scrutinizing studied to avoid any IP infringement. Commercialization law and company legalities in New Zealand were also studied for establishing the company.

\subsection{Development}

As a founding developer at Ripple Media Ltd, I had to plan, design, build, test, deliver and maintain the software product. The functional and non-functional requirements were gathered from the stakeholders, potential partners, journalists and mentors. The efforts were focused on delivering a viable product that would convince the New Zealand and global news publishing companies to collaboratively change and improve the way the news is funded.

\subsection{Deliverance}

Keeping in mind the future progressive growth of the business, an easily maintainable and sustainable solution was built. The product was evaluated based on the functional and nonrequirements and tested to meet the needs of the customers. Ripple Media Ltd is all set to deliver the values that were promised to the customers. The company is seeking out for any potential investments and other resources that can add value to the business. 


\section{References}

(n.d.). (Similar Tech) Retrieved 2 21, 2015, from https://www.similartech.com/categories/analytics

(n.d.). (MediaPass) Retrieved 2 21, 2015, from http://www.mediapass.com/mp/features

(n.d.). (Trello) Retrieved 2 17, 2015, from Trello: https://trello.com/

(2015, 2 25). Retrieved from Digital Ocean: https://www.digitalocean.com/

(2015, 2 25). Retrieved from CloudFlare: https://www.cloudflare.com/

(2015, 2 28). Retrieved from AdBlock: https://getadblock.com/

Advertising Age. (1999, 3 29). Retrieved 1 17, 2015, from http://adage.com/article/specialreport-the-advertising-century/ad-age-advertising-century-timeline/143661/

Advertising Standards Authority. (2013). Retrieved 1 17, 2015, from http://www.asa.co.nz/stats.php

Agile Manifesto. (n.d.). Retrieved 02 12, 2015, from http://www.agilemanifesto.org/ Alexander Osterwalder, Y. P. (2013). Business Model Generation: A Handbook for Visionaries, Game Changers, and Challengers. John Wiley \& Sons.

Capers Jones, V. a. (2014). Laws of Software Engineering Circa 2014. 25. Namcook Analytics.

Chesbrough, H. (2013). Open Business Models: How To Thrive In The New Innovation Landscape. Harvard Business Press.

Cleanslate. (n.d.). Retrieved 2 20, 2015, from http://cleanslatecss.com/

Commerce Commission New Zealand. (n.d.). Retrieved from http://www.comcom.govt.nz/business-competition/anti-competitive-practices/ Facebook OAuth. (n.d.). Retrieved 2 20, 2015, from https://developers.facebook.com/docs/reference/dialogs/oauth 
Fronczak, T. (2011, 3 31). Social Technology Review. Retrieved 02 9, 2015, from http://www.socialtechnologyreview.com/articles/single-sign-determining-singlesign-solution-your-website

Google OAuth. (n.d.). Retrieved 2 20, 2015, from https://developers.google.com/accounts/docs/OAuth2

GREENFIELD, R. (2012, 7 20). The Decline of Google (and the Internet's) Ad Business. Retrieved from The Wire: http://www.thewire.com/technology/2012/07/declinegoogle-and-internets-ad-business/54835/

Marketing Monitor. (2014, 1 13). Retrieved 1 17, 2015, from http://marketingweek.co.nz/2014/01/is-2014-the-year-of-the-nz-newspaperpaywall/

MCBETH, P. (2013, 08 22). NBR. Retrieved 01 2015, 21, from http://www.nbr.co.nz/article/fairfax-nz-annual-earnings-fall-15-percentoutperforming-australian-titles-bd-144767

Meteor. (n.d.). (Meteor) Retrieved 2 9, 2015, from https://www.meteor.com/

MILLER, C. C. (2012, 7 19). As Google Changes, Its Revenue Keeps Rising. Retrieved from The New York Times: http://www.nytimes.com/2012/07/20/technology/googlecontinues-growth-and-growing-pains.html?_r=2\&ref=technology

MoneyGram. (n.d.). Retrieved 2 16, 2015, from http://www.moneygram.co.nz/ MongoDB. (n.d.). Retrieved 2 9, 2015, from http://www.mongodb.org/

More Devs. (n.d.). Retrieved 2 23, 2015, from http://www.moredevs.ro/mysql-vs-mongodbperformance-benchmark/

MySQL. (n.d.). Retrieved 2 23, 2015, from http://www.mysql.com/

Neuhaus, A. (2015, 2 25). Let browsers cache static files to greatly speed up your site. Retrieved from Zargony: http://zargony.com/2009/01/22/let-browsers-cache-staticfiles-to-greatly-speed-up-your-site 
Newspaper Association of America. (2014, 4 18). Retrieved 1 17, 2015, from http://www.naa.org/Trends-and-Numbers/Newspaper-Revenue/Newspaper-MediaIndustry-Revenue-Profile-2013.aspx

Noel, A. (2013, 5 17). Simple Talk. Retrieved 2 17, 2015, from https://www.simpletalk.com/opinion/opinion-pieces/some-laws-of-software-development/

OAuth. (n.d.). Retrieved 2 20, 2015, from http://oauth.net/2/

Phillips, A. (2014). Journalism in Context: Practice and Theory for the Digital Age. Routledge. PHP. (n.d.). Retrieved 2 23, 2015, from http://php.net/

PIWIK. (n.d.). Retrieved 02 2015, 15, from http://piwik.org/

The Rules of Extreme Programming. (2015, 2 28). Retrieved from Extreme Programming: http://www.extremeprogramming.org/rules.html

THOMPSON, D. (2013, 3 18). The Atlantic. Retrieved 01 17, 2015, from http://www.theatlantic.com/business/archive/2013/03/this-is-the-scariest-statisticabout-the-newspaper-business-today/274125/

Twitter OAuth. (n.d.). Retrieved 2 20, 2015, from https://dev.twitter.com/oauth

Visual Studio Gallery. (n.d.). Retrieved 2 24, 2015, from https://visualstudiogallery.msdn.microsoft.com/ede12aa8-0f80-4e6f-b15c7a8b3499370e

W3C. (n.d.). Retrieved 18 02, 2015, from http://www.w3.org/TR/cors/

Wikipedia. (n.d.). Retrieved 2 9, 2015, from http://en.wikipedia.org/wiki/Single_sign-on Wikipedia. (n.d.). Retrieved 2 13, 2015, from http://en.wikipedia.org/wiki/Functional_requirement

Wikipedia. (n.d.). Retrieved 2 13, 2015, from en.wikipedia.org/wiki/Nonfunctional_requirement

Yahoo OAuth. (n.d.). Retrieved 2 20, 2015, from https://developer.yahoo.com/oauth/ 
TECHNICAL CHALLENGES OF A LIGHTWEIGHT, SCALABLE, GLOBAL PAYWALL SYSTEM 


\section{Personal information}

\section{Online news survey}

This survey asks for information about your news reading habits, and also explores your opinions about paying for access to news. The survey takes about 10 minutes to complete, and answers will be kept anonymous.

\section{Background:}

Our team is researching the future of online news, searching for ways to improve the way that journalism is funded, created and shared. We are undertaking this research as students within Victoria University's Master of Advanced Technology Enterprise programme. If you would like more information about our research then feel free to contact our team leader, Alex Clark (alex.clark@vuw.ac.nz).

\section{Defining news and journalism:}

This survey uses a very broad definition of news and journalism. Our definition includes established news outlets, as well as blogs and other forms of social commentary about current events.

\section{Section 1) Background information}

Please provide some background information about yourself.

\section{1) What is your age?}
Under 18
18-24
25-30
- $41-50$

( $31-40$

. $51-60$

61+

\section{2) Are you a student?}

Yes

No

3) What is your annual income?
Under $\$ 15,000$
$\$ 15,000-\$ 40,000$
$\$ 40,001-\$ 80,000$
- $\$ 80,000+$
Prefer not to disclose 
4) If you are happy to be contacted with follow-up questions, please provide your details below:

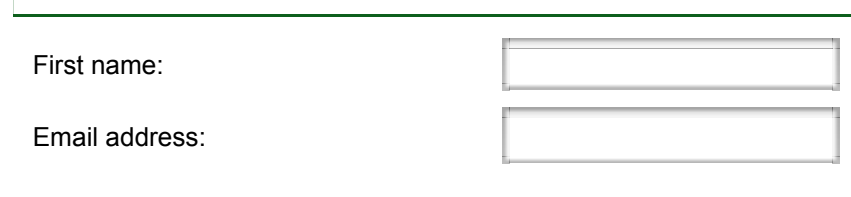

\section{Section 2) Your news reading habits}

\section{1) How often do you visit news websites?}

\footnotetext{
Never

Hardly ever (once per week, or less)

Occasionally (several times a week)

Often (several times per day)
}

\section{2) Approximately how many news websites do you visit each week?}
None
○ 1
$2-3$
4-10
$10+$

3) If you visit more than one news website, what are the main reasons?

Please tick all that apply

$\square$ I like to access a diverse range of perspectives and opinions from multiple news sources.

$\square$ I like to visit a variety of news websites that specialise in different topics.

$\square$ I visit several sites via links posted on social media (i.e. Facebook, Twitter etc.)

$\square$ Other (please specify)

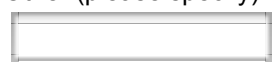

$\square$ I only visit one news website

4) Do you spend more time on New Zealand news sites, or overseas?

Mostly New Zealand news sites

Mostly overseas news sites

About the same amount of time 


\section{5) What are the main reasons that you read news?}

Please tick all that apply.

$\square$ Personal interest.

$\square$ It's important for my job.

$\square$ It's important for my studies.

$\square$ Other

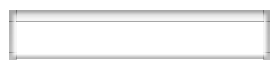

\section{6) What types of news do you read most often?}

Please tick all that apply.

\begin{tabular}{llll}
\hline$\square$ Local news & $\square$ Politics & $\square$ Technology/ Science & $\square$ Events \\
$\square$ National news & $\square$ Sport & $\square$ Entertainment/ Gossip & $\square$ Travel \\
$\square$ International news & $\square$ Finance/ Business & $\square$ Arts/ culture & $\square$ Other
\end{tabular}

\section{7) Do you ever access news using the following platforms?}

Please tick all that apply.

Social networks (e.g. Facebook, Twitter, Linkedln, Quora, etc.)

Mobile apps (e.g. Flipboard, Feedly, Pulse, News360, etc.)

$\square$ RSS readers (e.g. FeedDemon, Newsblur, Newsgator, etc.)

$\square$ None of the above

\section{8) Do you pay for any of the following types of media content?}

Please tick all that apply

$\square$ Print subscription (newspapers or magazines)

Online news subscription

Pay TV (e.g. Sky Television)

Online video streaming subscription (e.g. Netflix)

Online music streaming subscription (e.g. Spotify)

$\square$ Digital media content from online stores (e.g. iTunes or Kindle)

$\square$ Other

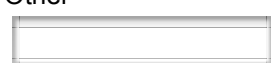

$\square$ None of the above

\section{9) Do you ever make credit card purchases online?}

Yes

No 
10) Do you own a smartphone (for example, an iPhone, Android or Windows Phone).

Yes
No

\section{Section 3 - Your thoughts about funding journalism}

This section asks for your opinions about different approaches to funding journalism.

Background information:

News organisations are losing a lot of money by putting their news online for free. For every $\$ 1$ they gain in online advertising, they currently experience a $\$ 16$ decrease in print advertising. As a result, news teams have become much smaller throughout the world and many publications are struggling to survive.

News organisations are currently looking for new revenue models to support the creation of high quality journalism. Over the next 12 months, most news websites in New Zealand and around the world are planning to charge readers for full access to their content.

Note: Statistics sourced from "The State of the News Media 2013," by the Pew Research Center's Project for Excellence in Journalism.

Imagine a scenario where all of your favourite news sites started charging for full online access:

1) How likely are you to pay for each of the following options?

\begin{tabular}{l|ccc}
\hline & Definitely not & Unlikely & Maybe \\
\hline $\begin{array}{l}\text { A small fee to access each } \\
\text { article. }\end{array}$ & & & Definitely \\
A monthly fee to access one \\
news website in New Zealand.
\end{tabular}

2) How much would you be prepared to pay?

\begin{tabular}{|c|c|c|c|c|c|c|c|c|}
\hline & $\$ 0$ & $\$ 1-3$ & $\$ 4-6$ & $\$ 7-9$ & $\$ 10-12$ & $\$ 13-15$ & $\begin{array}{l}\text { More than } \\
\quad \$ 15\end{array}$ & Unsure \\
\hline $\begin{array}{l}\text { A monthly fee to access one } \\
\text { news website in New Zealand. }\end{array}$ & 0 & 0 & 0 & 0 & 0 & $\mathrm{O}$ & 0 & 0 \\
\hline $\begin{array}{l}\text { A monthly fee to access all news } \\
\text { websites in New Zealand }\end{array}$ & 0 & 0 & 0 & 0 & 0 & 0 & 0 & 0 \\
\hline $\begin{array}{l}\text { A monthly fee to access all news } \\
\text { websites in the world. }\end{array}$ & 0 & 0 & 0 & 0 & 0 & 0 & 0 & 0 \\
\hline $\begin{array}{l}\text { A monthly fee to access all news } \\
\text { websites, as well as TV shows, } \\
\text { movies, music and other media. }\end{array}$ & 0 & 0 & $\mathrm{O}$ & 0 & 0 & $\mathrm{O}$ & 0 & 0 \\
\hline
\end{tabular}




\section{3) Have you ever encountered a paywall on a news website?}

Note: A paywall blocks news articles that you want to read, and asks you to pay for access.

Yes
No

4) Have you ever paid money for access to a news website?

Yes

No

\section{5) What do you think are the biggest barriers to paying for online news?}

Please tick all that apply.

$\square$ There are free alternatives that I can easily switch to

$\square$ I think that online news should be free

$\square$ I can't afford to pay for online news

$\square$ I don't like making payments online

$\square$ I access news from many sites and it is unrealistic to pay for each individually

$\square$ Other

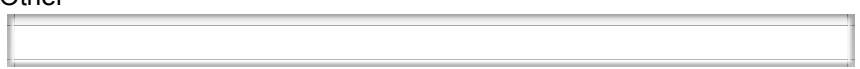

Please feel free to share your thoughts about the payment options above, and to explain the reasons for your answers within this section.

In the previous section, you indicated that you would consider purchasing a subscription to an individual news website. If you had to pay for each news website separately, what is the maximum number of websites that you would consider subscribing to?
1
2
3
4 or more
unsure 
In the previous section of this survey, you said that you would consider paying for news if you could gain access to more than one website. What do you think are the biggest benefits of this approach?

Please tick all that apply

It is cheaper than paying for multiple subscriptions.

It is more convenient than creating multiple subscriber accounts.

It provides access to a diverse range of opinions and perspectives from multiple sources.

It provide access to a variety of news websites that specialise in different topics.

Other

(n)

Please feel free to explain your preference for this option in more depth.

Imagine a scenario where general news stories remained free, but you had the option to pay for extras:

1) How likely are you to pay for each of the following options?

\begin{tabular}{|c|c|c|c|c|c|}
\hline & Definitely not & Unlikely & Maybe & Probably & Definitely \\
\hline $\begin{array}{l}\text { A monthly fee to remove } \\
\text { advertising. }\end{array}$ & 0 & 0 & 0 & 0 & 0 \\
\hline $\begin{array}{l}\text { A monthly fee for a news app on } \\
\text { your mobile or tablet. }\end{array}$ & 0 & 0 & 0 & 0 & 0 \\
\hline $\begin{array}{l}\text { A monthly fee to access premium } \\
\text { news content, such as } \\
\text { investigative reporting, extended } \\
\text { articles and interactive } \\
\text { multimedia. }\end{array}$ & 0 & 0 & 0 & 0 & 0 \\
\hline $\begin{array}{l}\text { A monthly donation to support } \\
\text { your favourite news website or } \\
\text { blogger. }\end{array}$ & 0 & 0 & 0 & 0 & 0 \\
\hline $\begin{array}{l}\text { A donation to support the creation } \\
\text { of specific stories that you are } \\
\text { interested in. In this scenario, } \\
\text { journalists would pitch story ideas } \\
\text { about important topics or issues } \\
\text { and news readers would fund } \\
\text { them. }\end{array}$ & 0 & 0 & 0 & 0 & 0 \\
\hline
\end{tabular}


2) Still thinking about the scenario described above, how much would you be prepared to pay for each of the following options?

\begin{tabular}{|c|c|c|c|c|c|c|c|c|}
\hline & $\$ 0$ & $\$ 1-3$ & $\$ 4-6$ & $\$ 7-9$ & $\$ 10-12$ & $\$ 13-15$ & $\begin{array}{l}\text { More than } \\
\quad \$ 15\end{array}$ & Unsure \\
\hline $\begin{array}{l}\text { A monthly fee to remove } \\
\text { advertising. }\end{array}$ & 0 & 0 & 0 & 0 & 0 & 0 & 0 & 0 \\
\hline $\begin{array}{l}\text { A monthly fee for a news app on } \\
\text { your mobile phone or tablet. }\end{array}$ & 0 & 0 & 0 & 0 & 0 & 0 & 0 & 0 \\
\hline $\begin{array}{l}\text { A monthly fee to access } \\
\text { premium news content. }\end{array}$ & 0 & 0 & 0 & 0 & 0 & 0 & 0 & 0 \\
\hline $\begin{array}{l}\text { A monthly donation to support } \\
\text { your favourite news website or } \\
\text { blogger. }\end{array}$ & 0 & 0 & 0 & 0 & 0 & 0 & 0 & 0 \\
\hline $\begin{array}{l}\text { A donation to support the } \\
\text { creation of specific stories that } \\
\text { you are interested in. (Please } \\
\text { estimate a monthly amount). }\end{array}$ & 0 & 0 & 0 & 0 & 0 & 0 & 0 & 0 \\
\hline
\end{tabular}

Please feel free to share your thoughts about the payment options above, and to explain the reasons for your answers within this section. Imagine a scenario where all news remained free, but new advertising techniques were used to earn
more money:

\section{1) How would you feel about the following options?}

\begin{tabular}{|c|c|c|c|c|c|}
\hline & Stongly dislike & Dislike & No strong feelings & Like & Like very much \\
\hline $\begin{array}{l}\text { An increase in articles that are } \\
\text { paid for by advertisers, and } \\
\text { promote their products or } \\
\text { services. }\end{array}$ & 0 & O & $\mathrm{O}$ & 0 & 0 \\
\hline $\begin{array}{l}\text { An increase in the number of } \\
\text { advertisements. }\end{array}$ & O & 0 & 0 & 0 & 0 \\
\hline $\begin{array}{l}\text { An increase in the prominence } \\
\text { of advertisements. (For } \\
\text { example, ads that cover the } \\
\text { entire page or videos that play } \\
\text { automatically). }\end{array}$ & 0 & 0 & 0 & O & 0 \\
\hline
\end{tabular}

If you had to choose, would you rather pay for news, or experience an increase in advertising?
Pay for news
Increase in advertising
Unsure

Please feel free to share your thoughts about the advertising techniques described above, and to explain the reasons for your answers within this section. 
Please feel free to share your thoughts about funding online news.

Do you think it is reasonable to pay?

Do you think there are better alternative forms of funding?

Are there features or services that would increase your likelihood to pay?

Please feel free to share your thoughts about online news journalism.

What do you like most about online news?

What do you think could be improved? 


\section{The Business Model Canvas}

\begin{tabular}{|c|c|c|c|c|c|c|}
\hline \multirow{3}{*}{$\begin{array}{l}\text { Key Partners } \\
\text { Publishing Partners } \\
\text {-Enterprise publishers } \\
\text {-Independent journalists } \\
\text { Open Source Partners } \\
\text {-Knight Foundation News } \\
\text { Challenge } \\
\text {-Knight-Mozilla } \\
\text { OpenNews } \\
\text {-Catalyst IT } \\
\text {-Piwik } \\
\text { Promotional and sales } \\
\text { partners } \\
\text {-publishers } \\
\text {-providers of } \\
\text { complementary } \\
\text { multimedia content (i.e. } \\
\text { music streaming, TV } \\
\text { streaming etc) } \\
\text {-ISPs } \\
\text {-Discount partners } \\
\text { Payment infrastructure } \\
\text {-Credit card processors } \\
\text {-Paypal } \\
\text {-Banks }\end{array}$} & \multirow{2}{*}{\multicolumn{2}{|c|}{$\begin{array}{l}\text { Key Activities } \\
\text {-Market Research } \\
\text {-Customer Acquisition: } \\
\text {-publishers and } \\
\text { journalists } \\
\text {-subscribers } \\
\text {-Platform Development and } \\
\text { Maintenance } \\
\text {-Collection and distribution of } \\
\text { royalty pool } \\
\text {-Customer Support }\end{array}$}} & \multirow{2}{*}{\multicolumn{2}{|c|}{$\begin{array}{l}\text { Value Propositions } \\
\text { Publishing partners } \\
\text {-increase proportion of } \\
\text { newsreaders willing to pay } \\
\text { for news, and the amount } \\
\text { that they pay } \\
\text {-a non-exclusive and open } \\
\text { platform, able to build } \\
\text { equitable partnerships } \\
\text { across competitive rivalries. } \\
\text {-robust and secure paywall } \\
\text { solution } \\
\text {-simple implementation }\end{array}$}} & & \multirow{3}{*}{$\begin{array}{l}\text { Customer Segments } \\
\text { Publishing Partners } \\
\text {-Enterprise publishers } \\
\text {-Independent journalists } \\
\text { Newsreaders } \\
\text {-Younger readers (18-30) } \\
\text {-Older readers (31+) } \\
\text {-Educational institutions } \\
\text {-Public libraries } \\
\text {-Niche readers (i.e. } \\
\text { finance/ sports/ tech etc.) }\end{array}$} \\
\hline & & & & & $\begin{array}{l}\text { Publishing partners } \\
\text { We provide: } \\
\text {-technical assistance } \\
\text {-content analytics } \\
\text {-subscriber conversion } \\
\text {-royalty distribution } \\
\text { Newsreaders } \\
\text { We provide: } \\
\text {-user accounts/ subscription } \\
\text {-customer support } \\
\text {-access to publishing partners }\end{array}$ & \\
\hline & \multicolumn{2}{|c|}{$\begin{array}{l}\text { Key Resources } \\
\text {-Ripple Media team } \\
\text {-Research findings } \\
\text {-Ripple platform and } \\
\text { technical infrastructure } \\
\text {-Publishing partners } \\
\text {-Open source partners } \\
\text {-Funding partners } \\
\text {-Promotional partners } \\
\text {-University networks } \\
\text {-Registered users and } \\
\text { paying subscribers }\end{array}$} & \multicolumn{2}{|c|}{$\begin{array}{l}\text { Newsreaders } \\
\text {-Easy access to premium } \\
\text { content from a diverse } \\
\text { range of news sources. } \\
\text {-value/ cost-reduction } \\
\text {-accessibility/ } \\
\text { convenience } \\
\text {-independence/ neutrality } \\
\text {-discovery of new content } \\
\text {-higher quality content }\end{array}$} & $\begin{array}{l}\text { Channels } \\
\text { Subscriber acquisition: } \\
\text {-sales pipeline through partner } \\
\text { websites } \\
\text {-promotional and sales partners } \\
\text {-advertising campaigns } \\
\text { Publisher acquisition: } \\
\text {-research and domain expertise } \\
\text {-media coverage } \\
\text {-warm intros + cold emails/calls }\end{array}$ & \\
\hline \multicolumn{2}{|c|}{$\begin{array}{l}\text { Cost Structure } \\
\text { Current costs: } \\
\text {-technical (hosting, domain name registration..) } \\
\text {-administrative (company incorporation..) } \\
\text {-travel (to Auckland, to conferences, to USA..) }\end{array}$} & \multicolumn{2}{|c|}{$\begin{array}{l}\text { Likely future costs: } \\
\text {-team expansion } \\
\text { (developers, sales, } \\
\text { marketing, finance etc) } \\
\text {-technical infrastructure } \\
\text {-promotion \& marketing } \\
\text {-royalty and payment fees }\end{array}$} & \multicolumn{3}{|c|}{$\begin{array}{l}\text { Revenue Streams } \\
\text { Enterprise publishers: } \\
\text {-subscription revenue (commission from royalty pool) } \\
\text { Independent journalists: } \\
\text {-donation revenue (commission from royalty pool) }\end{array}$} \\
\hline
\end{tabular}

www.businessmodelgeneration.com 
APPENDIX A

ENTERPRISE CASE STUDY:

PRESSPASS

BY

\title{
PUNEETH ANANDARAJ AND ALEXANDER CLARK
}

\author{
Submitted to the Victoria University of Wellington \\ In partial fulfilment of the requirements for the degree of \\ Master of Advanced Technology Enterprise
}

Victoria University of Wellington

2015 


\section{TABLE OF CONTENTS}

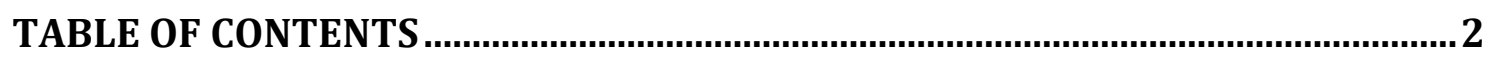

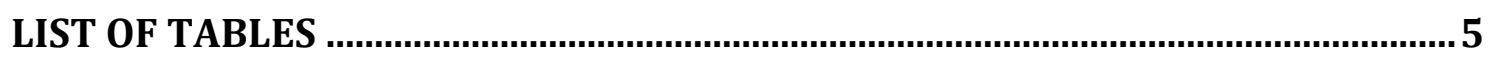

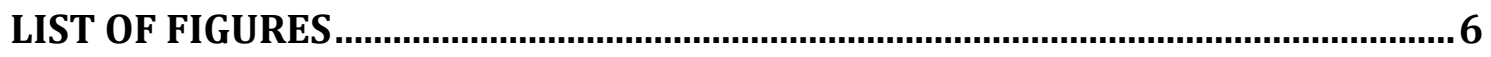

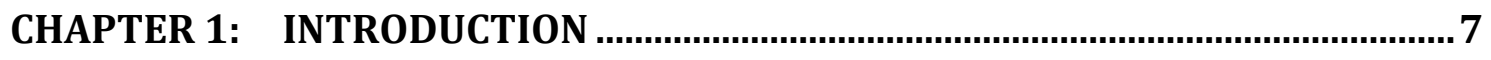

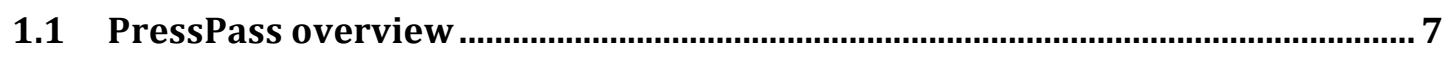

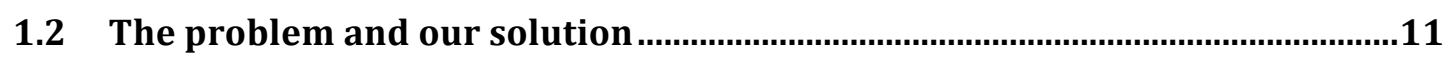

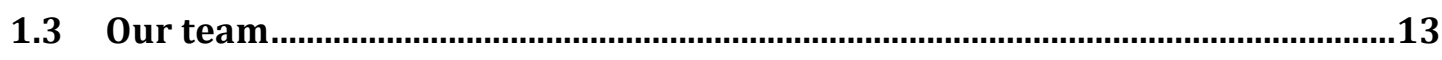

Alex Clark - Founder and CEO_.......................................................................................... 13

Puneeth Anandaraj - Founding Developer.......................................................................... 14

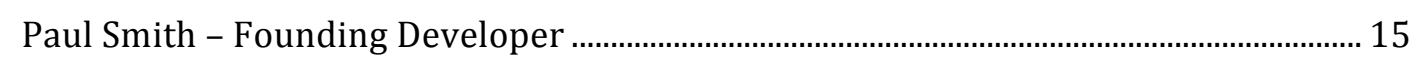

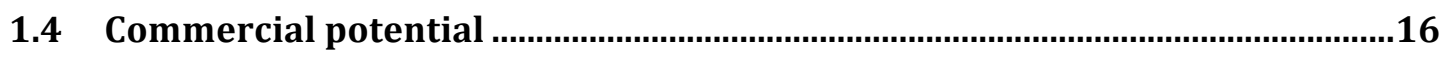

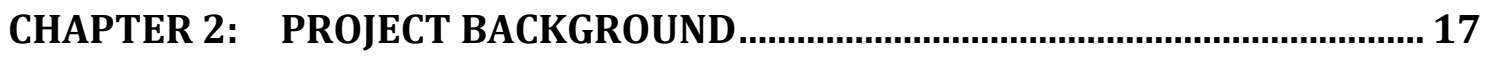

2.1 Project seed: 'Digital Commons or Digital Enclosures' .......................................17

2.2 Project proposal: 'News, Renewed' ..........................................................................18

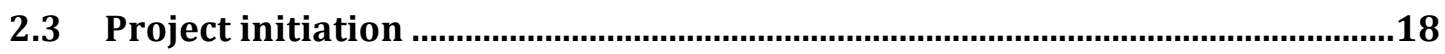

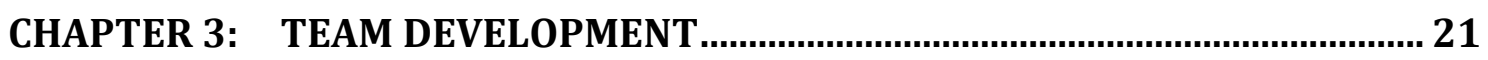

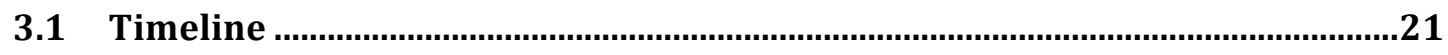

3.2 Team development: outcomes and strategy …….............................................22

CHAPTER 4: $\quad$ MARKET RESEARCH, CONSUMERS ............................................. 27

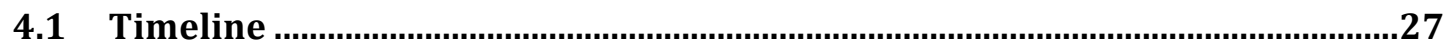

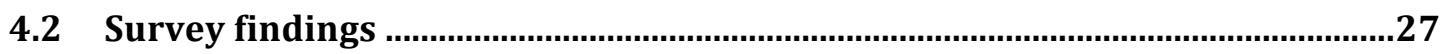

4.3 Identifying the best funding strategy for PressPass..............................................32

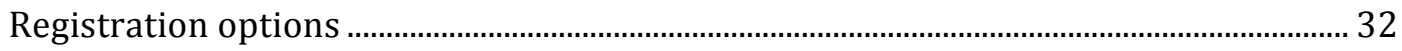

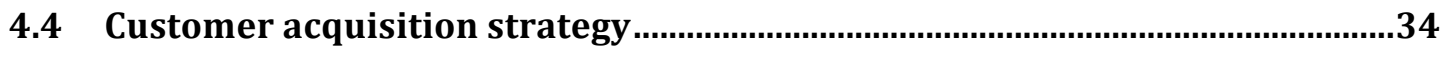

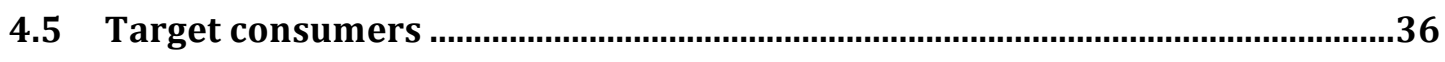

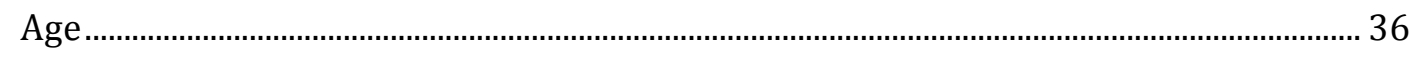

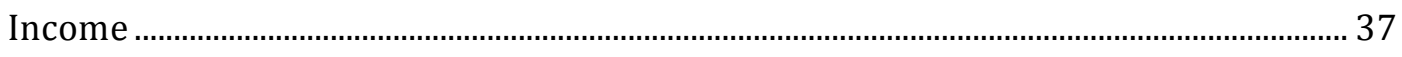

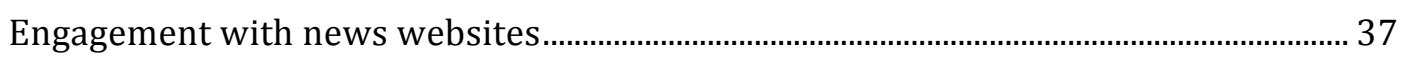

Media purchasing habits.................................................................................................. 39 
CHAPTER 5: MARKET RESEARCH AND PARTNERSHIP DEVELOPMENT,

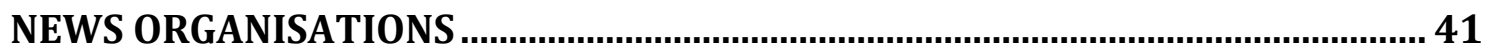

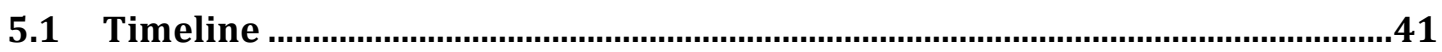

5.2 Partnership development activities .................................................................

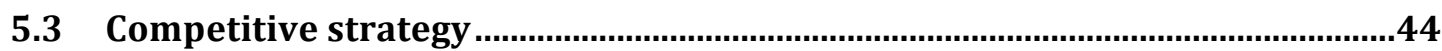

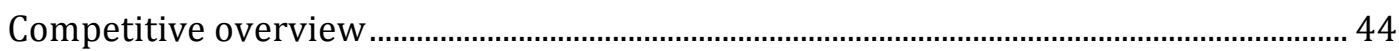

Competitive advantage ....................................................................................................... 45

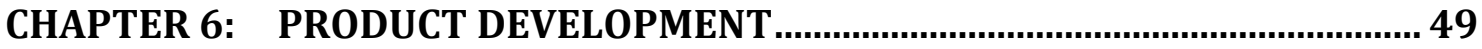

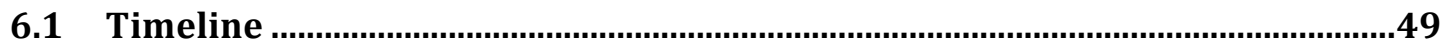

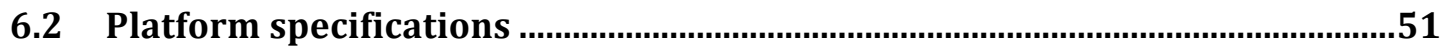

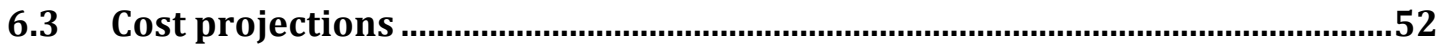

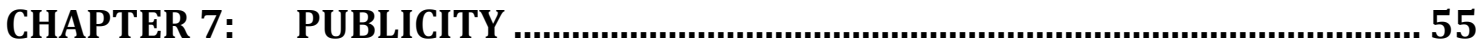

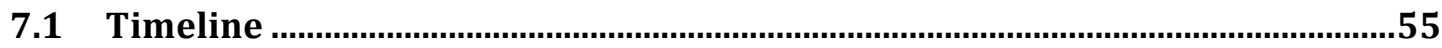

7.2 Publicity outcomes and strategy

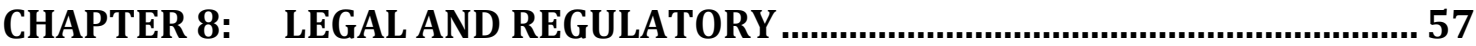

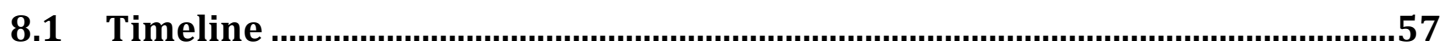

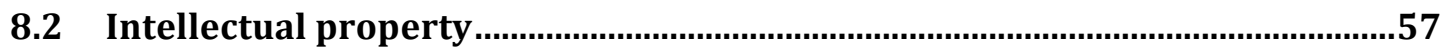

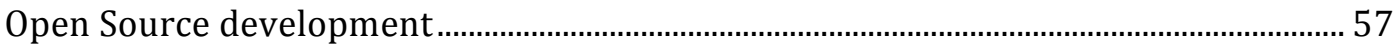

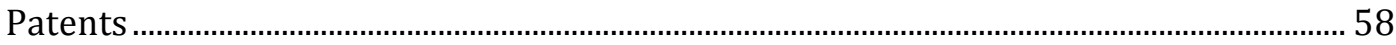

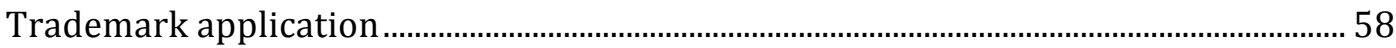

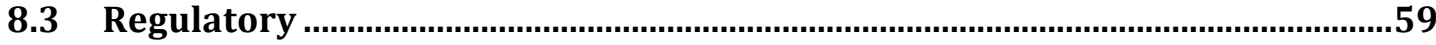

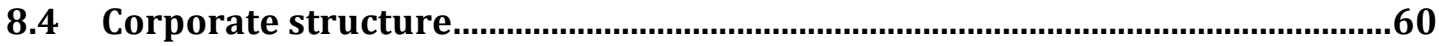

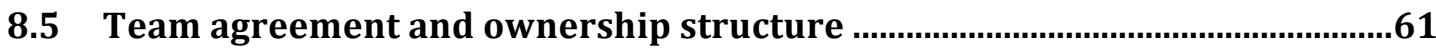

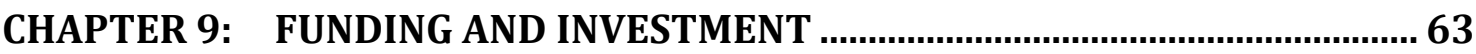

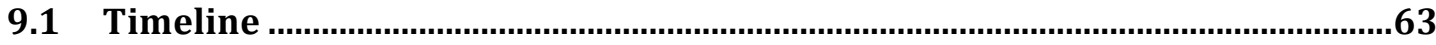

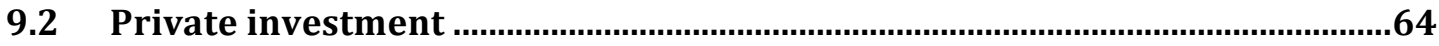

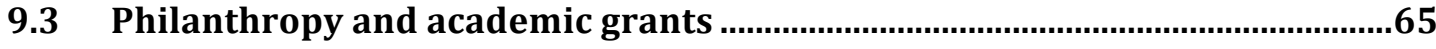

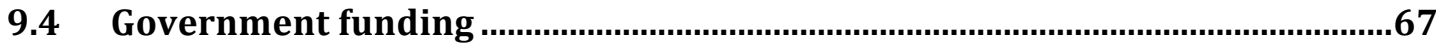

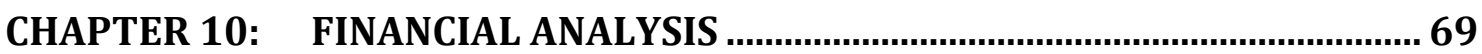

10.1 Pricing, commission structure and royalty distribution...................................69

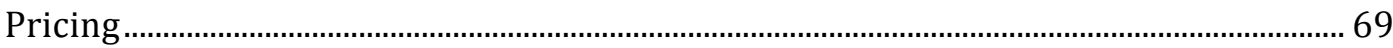

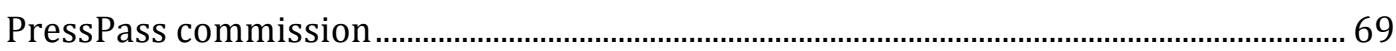

Conversion commission.............................................................................................................. 70 
Royalty distribution. 70

Revenue flow: hypothetical breakdown 70

10.2 Financial model comparing a standalone strategy with global bundling ..71

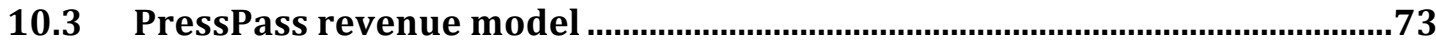

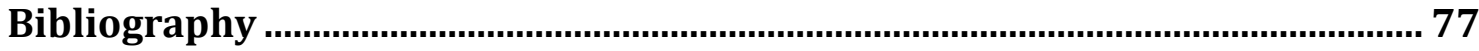




\section{LIST OF TABLES}

Table 1. Team development: Timeline of key milestones and activities..................................................... 21

Table 2. Market research, consumers: Timeline of key milestones and activities......................................... 27

Table 3. Monetisation strategies explored within survey .............................................................................. 28

Table 4. Market research, news organisations: Timeline of key milestones and activities........................ 41

Table 5. Roles of interviewees within news organisations ....................................................................... 42

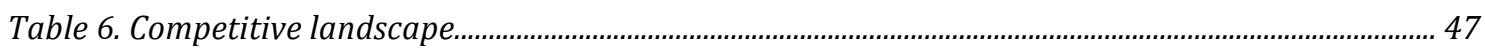

Table 7. Product development: Timeline of key milestones and activities................................................. 49

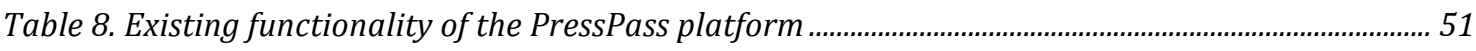

Table 9. Current development tasks for the PressPass platform ................................................................. 52

Table 10. Future plans for adding extra functionality to the PressPass platform ....................................... 52

Table 11. Cost of Virtual Private Server (VPS) at different scales of usage, for current specifications.. 53

Table 12. Publicity: Timeline of key milestones and activities .................................................................... 55

Table 13. Legal and regulatory: Timeline of key milestones and activities................................................... 57

Table 14. Funding and investment: Timeline of key milestones and activities ......................................... 63

Table 15. Estimated revenue under standalone package, all news organisations...................................... 72

Table 16. Estimated revenue under a standalone package, New Zealand Herald ..................................... 73

Table 17. Total revenue under a global bundling strategy, all publishing partners................................ 73

Table 18. Estimated revenue under a global bundling strategy, New Zealand Herald............................. 73

Table 19. Revenue model for New Zealand, high conversion rate estimate ................................................ 74

Table 20. Revenue model for New Zealand, medium conversion rate estimate ......................................... 75

Table 21. Revenue model for New Zealand, low conversion rate estimate..................................................... 75

Table 22. Revenue model for Australian expansion, low conversion rate estimate..................................... 75

Table 23. Revenue model for USA expansion, low conversion rate estimate ................................................. 76 


\section{LIST OF FIGURES}

Figure 1. Step 1 of the PressPass user experience 8

Figure 2. Step 2 of the PressPass user experience 8

Figure 3. Step 3 of the PressPass user experience 9

Figure 4. Step 4 of the PressPass user experience 10

Figure 5. Step 5 of the PressPass user experience 11

Figure 6. Willingness to pay for news at different levels of packaging 29

Figure 7. Willingness to pay, 18-30 year olds 30

Figure 8. Willingness to pay for news under alternative funding strategies 31

Figure 9. Willingness to pay for a global news package (age) 36

Figure 10. Willingness to pay for a global news package (income) 37

Figure 11. Willingness to pay for a global news package (number of news sites visited each week) _ 38

Figure 12. Willingness to pay for a global news package (frequency of visits) 38

Figure 13. Willingness to pay for a global news package (proportion of time spent reading New Zealand sites versus international) 38

Figure 14. Willingness to pay for a global news package (type of news read most often) 39

Figure 15. Willingness to pay for a global news package (current media purchases) 39

Figure 16. Diagram of data flow required for the PressPass platform 54 


\section{CHAPTER 1: INTRODUCTION}

\subsection{PressPass overview}

PressPass provides bundled access to the world's best news websites, for one monthly subscription fee. Once registered, paying subscribers receive a universal login account that can be used to unlock premium news articles within any partner website. The platform integrates seamlessly with existing news websites, providing news organisations with full control over the editorial experience, including story selection and layout.

The codebase has been written using the JQuery programming language, allowing news organisations to integrate it into their existing websites by adding a line of JavaScript code. Once integrated, the platform provides paywall infrastructure, reader analytics, user authentication and payment collection. ${ }^{1}$

A brief summary of the PressPass user experience is provided below. Please note that this functionality is based on the core features of our prototype, and additional features are being planned.

Step 1: A user visits their chosen news website, by entering its URL into their browser. The PressPass platform appears as a thin blue ribbon along the top of the screen, and a counter lets users know the number of free articles they have (Figure 1).

\footnotetext{
${ }^{1}$ A full overview of the platform's features can be viewed within Section 6.2.
} 


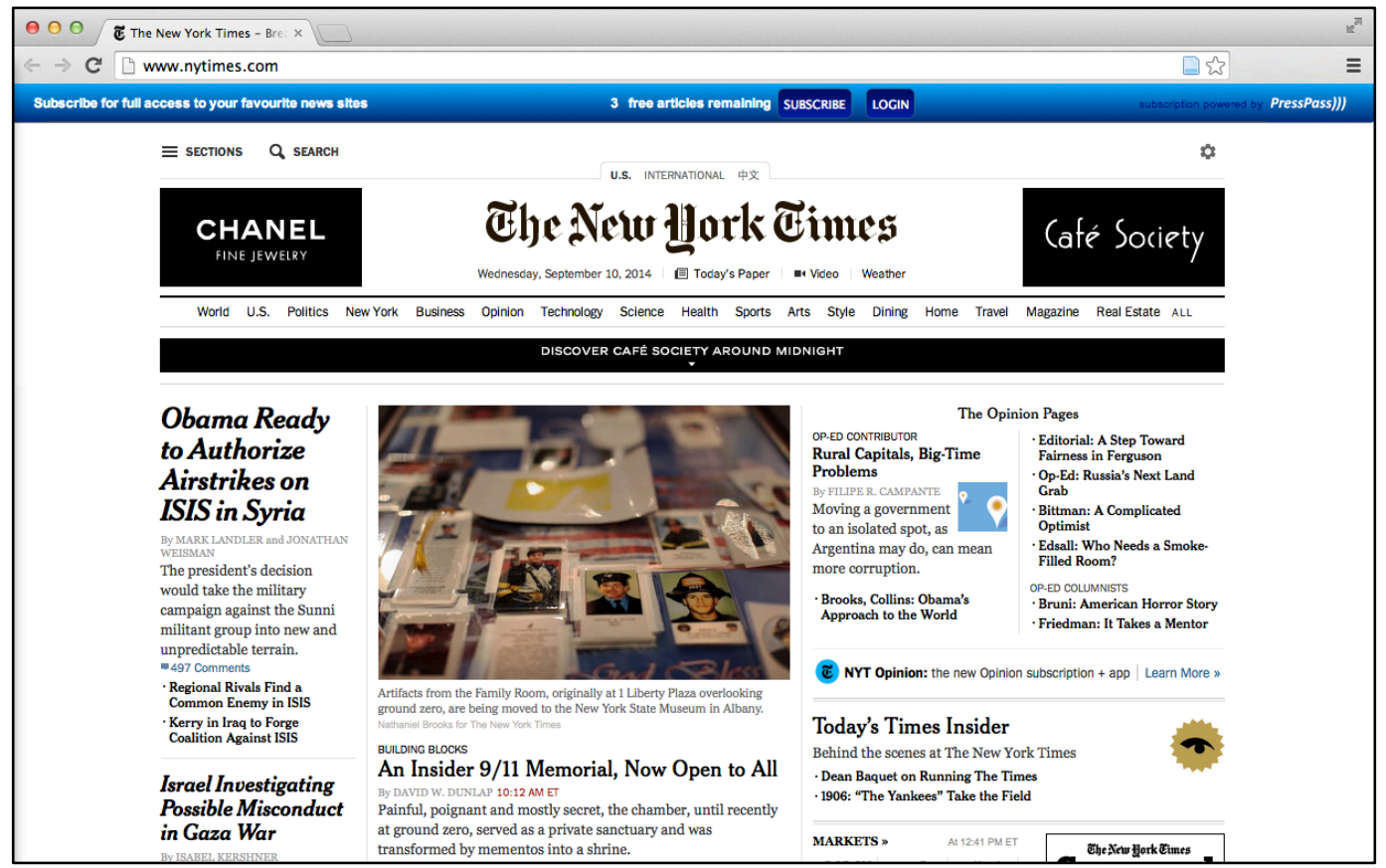

Figure 1. Step 1 of the PressPass user experience

Step 2: Once a user reaches their limit of free articles, the PressPass paywall appears and they are prompted to create an account. Readers can register their details by using an existing social media login, such as Facebook, or can create an account from scratch using an email address (Figure 2).

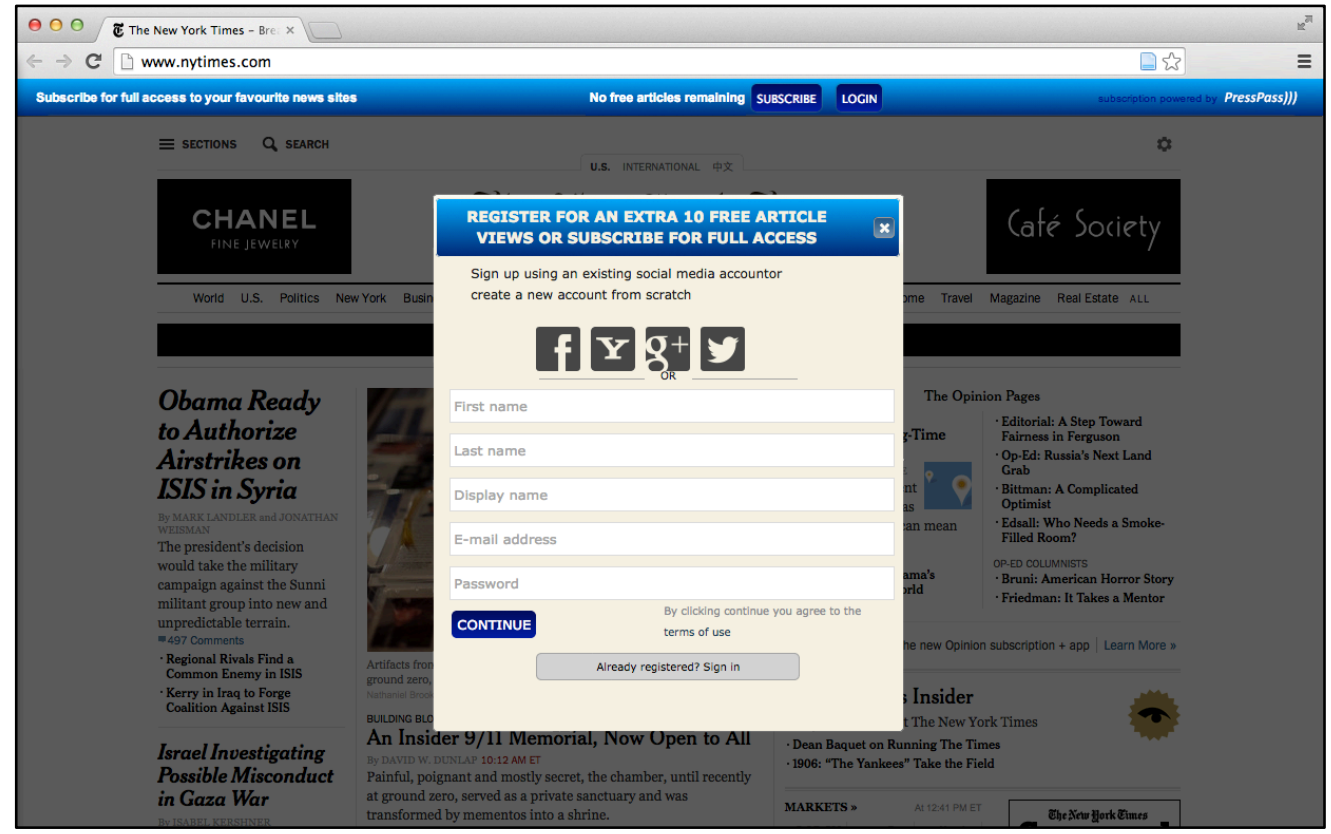

Figure 2. Step 2 of the PressPass user experience 
Step 3: After registering their details, readers choose from the following options (Figure $3)$.

- Free account: Readers register to receive additional free page views.

- Standalone subscription: Payment for full access to a single news website.

- National package: Payment for full access to all news partners within New Zealand.

- Global package: Payment for full access to all news partners in the world.

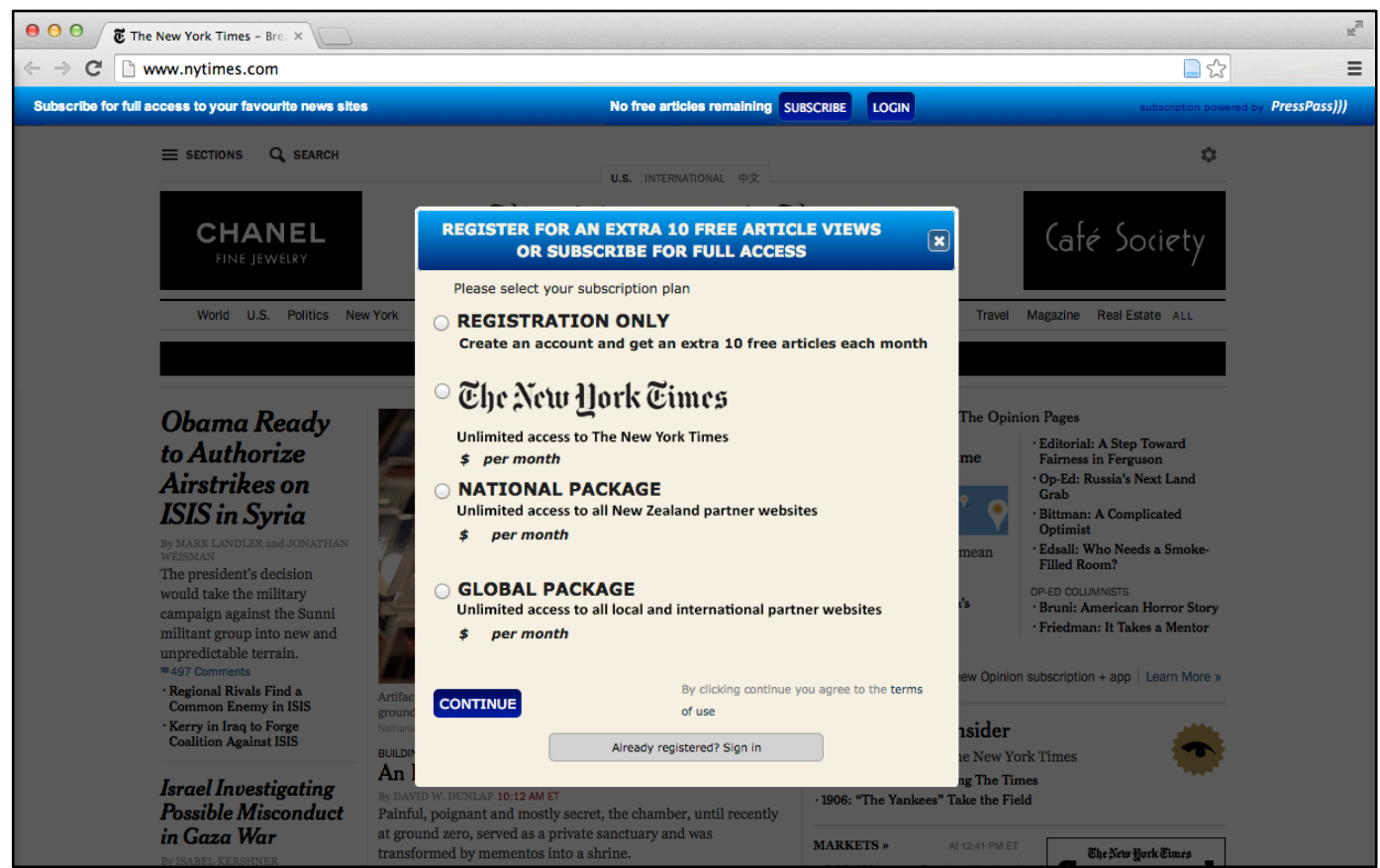

Figure 3. Step 3 of the PressPass user experience 
Step 4: The user then selects their payment method. They can use their credit card, PayPal account, internet banking account, or a subscription token ${ }^{2}$ (Figure 4).

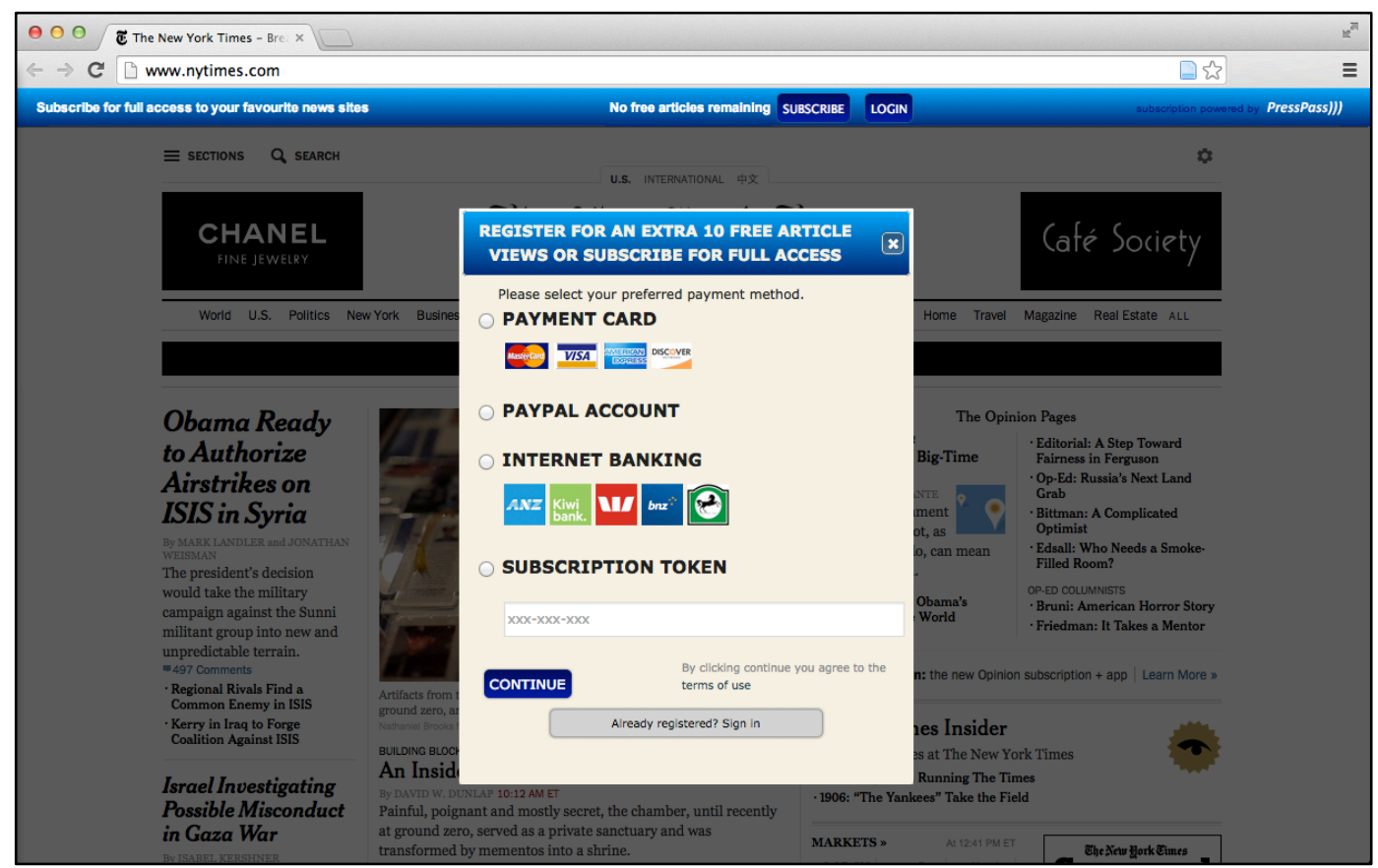

Figure 4. Step 4 of the PressPass user experience

Step 5: Once payment has been made, the user is logged in. If they have subscribed to the global package, they can use their universal login account to access premium content within any partner website (Figure 5).

\footnotetext{
${ }^{2}$ Subscription tokens can be purchased from selected retailers, or can be used by news organisations to provide their print subscribers with online access to their site.
} 


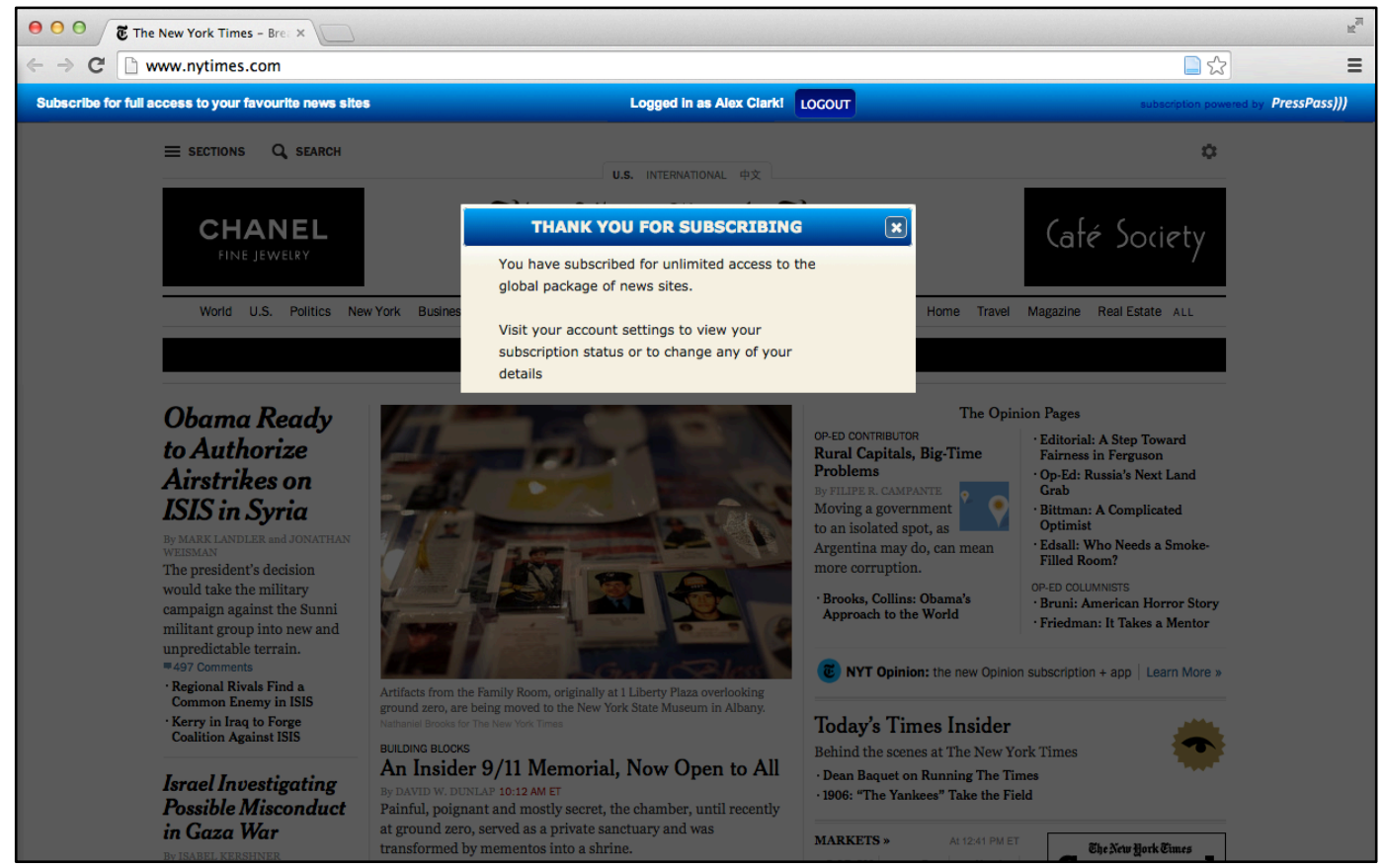

Figure 5. Step 5 of the PressPass user experience

\subsection{The problem and our solution}

The journalism community needs better monetisation strategies to fund the creation of news in an online environment. As audiences have shifted from print to online, print revenues have collapsed causing extensive disruption to the traditional business model of news organisations (Grueskin, Seave, \& Graves, 2011).

The primary business model pursued online has been to offer audiences free access, with revenue generated by online advertising (Siapera \& Veglis, 2012). When news organisations first launched websites, print revenue heavily subsidised the production costs of journalism disseminated online (Ibid). However, print revenues have since plummeted and online advertising revenues have not grown fast enough to fill the deficit (Ibid).

In the USA, it has been estimated that for every $\$ 1$ gained in online advertising revenue, $\$ 16$ in print advertising revenue is lost (The Pew Research Center, 2013). Ongoing revenue losses have resulted in American newsrooms being cut by $30 \%$ since 2000 (The Pew Research Center, 2013). 
In New Zealand, it has been estimated that between $\$ 18-19$ in print advertising is lost for every $\$ 1$ gained in online advertising (Fahy, 2014). Falling revenues have resulted in thousands of New Zealand journalists losing their jobs over the past decade, making it difficult to sustain quality journalism (Myllylahti, 2013).

In response to the shortfalls of online advertising, news organisations throughout the world have begun adopting an online subscription model. Across the USA, more than $50 \%$ of daily news websites now charge for full access (Doctor, 2012). In New Zealand, the country's two largest news websites are currently assessing plans to charge for full access to their news content (Gray, 2015; Pullar-Strecker, 2014).

NZME, who owns nzherald.co.nz, is currently planning a metered paywall ${ }^{3}$ across their New Zealand digital brands (APN News and Media, 2014). Fairfax, who owns stuff.co.nz, is considering subscriptions for specialist news content, such as business articles (Pullar-Strecker, 2014).

Internationally, online subscriptions have had mixed success. While paywalls can provide a much needed revenue boost in the short term, they often fail to compensate for continued losses from print. Only a small proportion of readers ever pay for digital subscriptions, and growth rates quickly plateau after initial uptake.

The USA's largest provider of paywall technology, Press + , states that the average paywall converts 0.5 percent of unique visitors into subscribers, while high performing sites convert between one and two percent (Ellis, 2014). The New York Times has one of the world's most successful paywalls, yet converts just 1.5 percent of its online readers into digital subscribers and uptake is plateauing (The New York Times, 2014).

Our market research has revealed that consumers are far more likely to pay for an online subscription if access to several news websites is bundled into national and global packages. Not only does bundling increase the number of paying subscribers, it also

\footnotetext{
${ }^{3}$ A metered paywall allows readers to view a certain number of free articles each month, before access is restricted and the user is prompted to pay for a subscription.
} 
increases the amount that subscribers are willing to pay for news. For a detailed overview of our market research findings, please view Section 4.2.

The PressPass platform was created to enable national and global packages of news. By providing the technical infrastructure required for bundled packages, we hope to empower news organisations to generate new revenue streams that are not possible under a standalone subscription strategy.

\subsection{Our team}

Below is a brief overview of team members working on the PressPass platform. For a more in-depth overview of team activities and strategy, see Chapter 3.

\section{Alex Clark - Founder and CEO}

From 2007-9, Alex was the editor of Tearaway Magazine, a youth publication distributed throughout New Zealand to an audience of 155,000 readers. His employment coincided with the 2008 Financial Crisis, and he experienced first-hand the subsequent decline in print advertising that impacted the journalism industry.

Following his work at Tearaway, Alex completed a Bachelor of Arts in Media Studies and International Relations at Victoria University. His final year was spent on exchange at the University of Texas at Austin and the University of California, Berkeley. While on exchange he studied journalism, internet and communications law, entrepreneurship and media management.

Upon his return to New Zealand Alex worked as a research assistant within Victoria University's School of Information Management, exploring the future of digital media. He also worked as a research assistant within Victoria Business School, looking at innovation within Wellington's ICT industry, in a joint initiative with Grow Wellington and the Wellington City Council.

Alex enrolled in the Master of Advanced Technology Enterprise so that he could explore ways to improve funding for online journalism, within a unique context that combined academic research with the development of a practical solution. 
Core roles and responsibilities:

- Project coordination: Create wireframes and specification documents, to inform the development work undertaken by Paul and Puneeth.

- Market research: Develop survey questions, distribute survey to online respondents and conduct face-to-face interviews with consumers and publishers.

- Partnership development: Establish relationships with the journalism community, by meeting with news organisations and independent journalists.

- Media engagement: Share the PressPass project with the wider journalism community via media outlets.

- Financial modelling: Develop models and projections to assess the financial viability of specific monetisation strategies.

- Miscellaneous: Company incorporation, registration of trademarks, purchase of web domains, and other administrative tasks.

\section{Puneeth Anandaraj - Founding Developer}

Puneeth is a developer with experience using several programming languages and frameworks, including: ASP.NET, HTML5, CSS, JavaScript, jQuery, Xamarin, Phonegap, C\#, C++, MySQL, and Oracle.

Puneeth has a Bachelor of Technology from the Amrita School of Engineering in India. After graduation, he worked for Infosys Limited for 2 years in the Education and Research department, specialising in .NET technologies. His core work was to provide entry-level training to recent graduates, as well as training for professional developers who needed to improve their technical skills.

Puneeth moved to New Zealand in 2011, and completed a Post-graduate Diploma in Computer Science at Victoria University. Upon graduation he started working as a .NET developer for NorthSouth GIS, and worked with mobile technologies, JavaScript development, and security.

Puneeth enrolled in the Master of Advanced Technology Enterprise so that he could apply his technical skills within an entrepreneurial context. After assessing the seed 
projects presented to students, he chose the PressPass project as the best way to achieve his goals.

Core roles and responsibilities:

- Development of the PressPass ribbon using JQuery.

- Design of the code structure and skeleton, enabling easy integration with other systems and easy implementation of new features.

- Implementation of social sign-on, using third-party authentication through providers such as Facebook.

- Design of the UI layout.

\section{Paul Smith - Founding Developer}

Paul is an open source developer with experience using several programming languages and frameworks, including: JavaScript, jQuery, Meteor, MongoDB, HTML, CSS, MySQL, and Zend.

Paul has been working as a freelance developer since 2006, working on a variety of projects ranging from website development and network maintenance, through to the project management of a design and manufacturing platform for kitchen bench-tops.

In 2012 he was an early contributor to Loomio, an open source platform that assists groups and organisations with collaborative decision-making. He has a passion for community-based projects, and has been a core organiser of the Taranaki TimeBank initiative.

Prior to joining PressPass, Paul was working on an open source web platform for collecting, assessing, discussing and categorising news from multiple sources. He is passionate about improving the news ecosystem through digital technology, and joined the PressPass team to help further this goal.

Core roles and responsibilities:

- Design and implementation of the CSS (style and design aesthetics).

- Implementation of the user interface for registration and subscription. 
- Implementation of the cross-domain-storage feature, using Meteor and MongoDB.

- Management of the server-side code.

\subsection{Commercial potential}

The PressPass platform empowers news organisations to implement a global bundling strategy, which has the potential to significantly increase their revenues. Financial modelling shows that the New Zealand journalism industry could earn an estimated $\$ 28$ million by participating in a global subscription package. This is nearly four times as much as the revenue that could be generated under a standalone subscription strategy (see Section 10.2).

PressPass itself has the potential to be a highly successful commercial enterprise. Within the New Zealand market, financial modelling shows that the platform could earn between $\$ 3.2$ and $\$ 12.9$ million through its commission earned on subscription sales. If the platform expands within the Australian market, a low estimate suggests that around $\$ 16.6$ million could be generated in commission revenue. For the USA, a low estimate indicates that commission revenue could be approximately $\$ 255$ million each year (see Section 10.3).

Due to the lightweight nature of the PressPass platform, infrastructure costs are projected to be low. An estimate calculated by Puneeth indicates that hosting could cost less than \$2,000 per month, even at extremely high levels of uptake. A lightweight platform also means that employment costs will likely be low for development and maintenance, especially during the early stages of the project.

The large profit margin between potential revenue and costs, puts PressPass in a healthy position to seek investment. However, as outlined in Section 9.1, it is important for the team to develop firmer commitments from potential publishing partners to maximise the platform's chance of success. 


\section{CHAPTER 2: PROJECT BACKGROUND}

PressPass was developed within the Master of Advanced Technology Enterprise (MATE) at Victoria University. MATE is an interdisciplinary programme that explores the relationship between academic research and commercial product development. At the start of the programme, students are presented with a selection of seed projects that focus on commercialising academic research. During a four-week introductory course, students select a project and establish teams that utilise their disciplinary expertise. Students then undertake activities essential to the success of their enterprise, such as market validation, product development and building customer relationships. Below is a summary of the formative stages that led to development of the PressPass platform.

\subsection{Project seed: 'Digital Commons or Digital Enclosures'}

Prior to the MATE programme, Alex Clark was a research assistant within the School of Information Management working on a project entitled, Digital Commons or Digital Enclosures: The Future of Online Content Distribution. Initiated in August 2013, the project involved interviews with journalists, musicians, authors and publishers, and explored the ways that creators chose to share their content online. The key focus was to better understand the factors that influence whether content is made freely available, or put behind restrictive barriers.

The research revealed a delicate tension within the creative industries: creators expressed a strong desire for their work to be openly accessible to as many people as possible, yet the process of creation has a range of associated costs that need to be funded. Within the creative industries there is widespread concern that online funding strategies are overly restrictive, impacting the ability to connect with audiences. Conversely, many funding strategies predicated on free online access are unable to fund creation.

Many interviewees expressed a strong interest in finding a middle ground between free open access and overly restrictive monetisation strategies. Repeatedly, interviewees pointed to the model of 'pay-once-access-all' bundling as a promising solution, citing 
the success of prominent industry examples such as Spotify and Netflix. Under these models, users pay one monthly fee for unlimited access to all content within the media ecosystem. Creators are then rewarded with royalty payments, allocated according to levels of audience engagement.

Interviewees also discussed a wide range of alternative funding strategies for online content. Despite the variety of ideas, there was widespread confusion as to which strategies were best suited for each type of content. This was compounded by a lack of qualitative data, particularly from comprehensive studies that assessed multiple strategies side-by-side. Furthermore, the technical infrastructure to enable these strategies was often limited or non-existent. The Digital Commons project highlighted the need for further research, so that better strategies could be identified and a solution built.

\subsection{Project proposal: 'News, Renewed'}

In December 2013, Alex Clark applied for the Master of Advanced Technology Enterprise, and submitted a proposal to expand upon the Digital Commons project. The proposal was entitled News, Renewed, and focused on improving the way that journalism is funded online. The journalism industry was chosen as a focus, due to the significant financial struggles being experienced by news organisations throughout the world (see Section 1.2).

The proposal was centred around two key objectives: to conduct a comparative analysis of multiple online funding strategies, and to build an online platform that enables the best funding strategy to be easily implemented by the journalism community. Puneeth Anandaraj was also applying for the MATE programme, and met with Alex several times during December to discuss the potential of the News, Renewed project.

\subsection{Project initiation}

On the $27^{\text {th }}$ of January 2014, Puneeth and Alex began the 4-week introductory programme for the Master of Advanced Technology Enterprise. During this period, they formally established a team around the News, Renewed project. After developing an 
enterprise plan outlining key activities and milestones, they began development of their enterprise in March 2014.

The following chapters summarise the enterprise activities undertaken during the first 12 months of development, as well as the resulting outcomes and strategies. Each chapter focuses on a particular aspect of enterprise development, as outlined below:

- Chapter 3: Team Development

- Chapter 4: Market Research, Consumers

- Chapter 5: Market Research, News Organisations

- Chapter 6: Product Development

- Chapter 7: Publicity

- Chapter 8: Legal and Regulatory

- Chapter 9: Funding and investment

- Chapter 10: Financial analysis 


\section{CHAPTER 3: TEAM DEVELOPMENT}

\subsection{Timeline}

Table 1. Team development: Timeline of key milestones and activities

\begin{tabular}{|c|c|}
\hline DATE & ACTIVITIES \\
\hline November 2013 & $\begin{array}{l}\text { Alex advertises the News, Renewed project to computer science } \\
\text { students at Victoria University and to the wider start-up community. }\end{array}$ \\
\hline December 2013 & $\begin{array}{l}\text { Puneeth Anandaraj and Alex Clark meet during the MATE application } \\
\text { process, and discuss the potential of the News, Renewed project. }\end{array}$ \\
\hline 17 January 2014 & $\begin{array}{l}\text { Alex meets with a web solutions delivery manager at } 3 \text { Months } \\
\text { (development company), to discuss components of PressPass that } \\
\text { could be outsourced. }\end{array}$ \\
\hline February 2014 & $\begin{array}{l}\text { Puneeth Anandaraj and Alex Clark form an official team within the } \\
\text { MATE programme during ATEN } 501 \text {. }\end{array}$ \\
\hline 6 March 2014 & $\begin{array}{l}\text { Weekly team mentoring sessions begin with Michael Elwood-Smith, a } \\
\text { business strategist with close ties to Wellington's start-up } \\
\text { community. }\end{array}$ \\
\hline 7 March 2014 & $\begin{array}{l}\text { Alex meets with two lecturers within the computer science } \\
\text { department, to discuss the possibility of aligning PressPass } \\
\text { development work with course outcomes. }\end{array}$ \\
\hline April 2014 & $\begin{array}{l}\text { Puneeth visits India, and during his trip meets with acquaintances } \\
\text { within the IT community to discuss the possibility of outsourcing } \\
\text { some components of PressPass development. }\end{array}$ \\
\hline 6 April 2014 & $\begin{array}{l}\text { Paul Smith, a developer from New Plymouth, reaches out to Alex } \\
\text { Clark via email after completing the consumer survey. He expresses } \\
\text { an interest in contributing to the PressPass project. }\end{array}$ \\
\hline April to May 2014 & Paul, Alex and Puneeth discuss the PressPass project via Skype. \\
\hline 20 June 2014 & $\begin{array}{l}\text { Paul Smith begins working with Puneeth on the source code, } \\
\text { contributing approximately } 10-20 \text { hours per week from this date } \\
\text { onwards. }\end{array}$ \\
\hline 4 July 2014 & $\begin{array}{l}\text { Alex Clark and Puneeth Anandaraj sign the PressPass team } \\
\text { agreement. }\end{array}$ \\
\hline 16 July 2014 & $\begin{array}{l}\text { Alex meets with a business development manager at Catalyst IT (open } \\
\text { source development company), to discuss components of PressPass } \\
\text { that could be outsourced. }\end{array}$ \\
\hline 15 August 2014 & Paul Smith signs the PressPass team agreement. \\
\hline 16 January 2014 & Puneeth renews the PressPass team agreement. \\
\hline 15 February 2014 & Paul Smith renews the PressPass team agreement. \\
\hline
\end{tabular}




\subsection{Team development: outcomes and strategy}

High-level summary:

- PressPass' team strategy is focused on building its internal capacity for core development tasks.

- All team members have signed a team agreement, which is reviewed every 6 months.

- Some outsourcing of development work may be considered, but only in situations where there is a clear advantage over internal capacity building.

- JavaScript has been chosen as the core development language, and future team members will need to be proficient in its usage.

- Our next major addition to the team will be a User Experience design to refine and enhance platform functionality and design (aim: by June 2015).

- Once news partnerships are established, we will start hiring our customer support team for readers and news organisations.

Alex first began the search for team members in November 2013, when he sent out requests to a database of computer science students at Victoria University. While he did receive some interest from several students, whom he met with on several occasions, it was difficult to find individuals with suitable skillsets and with an academic focus that aligned with the project. Alex also advertised in different forums associated with the Lightning Lab accelerator in Wellington and The Icehouse incubator in Auckland, and had conversations with several developers. While several individuals showed an interest in the concept, they were not willing to work without income.

Alex and Puneeth met in December 2014, to discuss the PressPass project. They also met with some of the computer science students and individuals from the start-up community who showed an initial interest in the project. Early meetings were focused on choosing a development language, and sketching up initial wireframes and specifications. Each potential team member had a slightly different development background, working with either open source or proprietary frameworks, as well as a variety of programming languages. 
Initial considerations explored the possibility of each team member programming a platform module in their own preferred language, with APIs (application programming interfaces) to form interconnections between each component. Module based development was soon dismissed as impractical, and instead it was decided to programme using JavaScript. While it JavaScript was not the core strength of every potential developer, it was a language that everyone had at least some proficiency in. It was also decided that Wellington's JavaScript community was stronger than for proprietary frameworks such as Microsoft's .NET, which would make it easier to build upon the team in future.

Within a few weeks most Victoria students indicated that it would not be possible to continue work on the project, largely due to academic commitments and the lack of a direct link to their own research. Puneeth, however, maintained a strong interest in the project and formally joined the team in February as part of the Master of Advanced Technology. Once the introductory coursework requirements for the MATE programme had been completed, Alex and Puneeth began work on the PressPass project in March. They also began weekly mentoring sessions with Michael Elwood-Smith, who worked with the PressPass team throughout the year to help refine their enterprise plan and development strategy.

Outside of the MATE programme, Alex explored ways to expand the development capacity of the project. In January he visited the development company, 3Months, to discuss the possibility of outsourcing some development tasks. In July, he met with the open source development company, Catalyst IT, to explore the same proposition. At this stage, Alex was hoping that the companies would be interested in doing some development work in return for equity or convertible notes. Each company, however, was not prepared to undertake such work due to the early stage of the project and their lack of available resources. Puneeth also explored the possibility of outsourcing, during a trip to India in May 2014, discussing the possibility with acquaintances within the IT community.

The advantages and disadvantages of outsourcing were discussed at length with our team mentor, Michael Elwood-Smith, as well as other members of Wellington's start-up community. It was advised that our focus should be on building the internal capacity of 
our team, and to only consider outsourcing in situations where it would provide a clear advantage. For example, if there was a one-off technical solution that required extremely specialised expertise, or if the team needed to meet an urgent deadline that would be impossible to meet internally. Furthermore, it was recommended that any outsourcing should be limited to New Zealand companies with direct accountability.

Each advisor emphasised the importance of having any outsourced developers strongly invested in the success of the project. Some recommended using equity as a motivating factor. Others advised against equity, saying it was better to maintain ownership and control, while achieving dedication to the project through other structural approaches. For example, contractual agreements could be created to include a buy-out clause, where the external team could eventually be integrated internally. Alternatively, a proportion of payment could be reserved for the ongoing success and maintenance of the features developed.

Alex and Puneeth are still open to the possibility of outsourcing for some tasks, however, their core focus is to develop the internal capacity of their team. Any outsourcing undertaken will be carefully considered, only in situations where it provides us with a clear advantage over internal capacity building, and with a development team who is invested in the success of our project.

Another activity that Alex undertook to expand the team, was to meet with two lecturers within the computer science department at Victoria University. Alex hoped to identify a way to align PressPass development with academic outcomes for undergraduate and graduate students. While there was some interest in the idea, the lecturers highlighted that it would be difficult to align development with course outcomes due to the specific goals of each course and research project.

In April, a developer named Paul Smith reached out to Alex via email. Paul had completed Alex's consumer survey online, and was interested in learning more about the News, Renewed project. An open source developer from New Plymouth, Paul had been working on his own news platform for several months. He was passionate about improving online journalism, and wanted to explore ways in which he could contribute to the PressPass platform. Throughout April and May, Puneeth and Alex had regular 
discussions with Paul. During these calls they learnt more about each other's background, shared information about existing code and specifications, and discussed Paul's availability.

On the $20^{\text {th }}$ of June 2014, Paul joined the team and began contributing approximately 10-20 hours each week. Over the following months, Puneeth and Paul worked together to develop the PressPass prototype (see Chapter 6 for further details about the development process). Between them, they found that their complementary skillsets allowed them to develop all of the core features of the PressPass prototype.

As development of the PressPass platform progressed, it became increasingly important to have a team agreement that outlined roles and mutual expectations about the project. The team agreement was signed by each team member over July and August, and formed a foundation upon which the team could explore the potential of the PressPass project. Further details about the team agreement can be found within our legal section, in Chapter 8.

For the next stages of development, the team has identified that a user experience designer will be useful to further refine the design and functionality of the PressPass platform during preparation for launch. Aside from product development, other roles relevant to launch will be need to be filled. Once firm partnerships have been established with news organisations, the team will begin looking at ways to expand its capability, particularly in regards to customer support for readers and publishers. Some positions will need to be part of our core team, such as customer support for publishers, particularly as we expand the number of news partners. Other roles could potentially be outsourced, such as call centre support for readers, ideally within New Zealand.

Other core roles that advisors have recommended, include: Chief Operating Officer, Chief Financial Officer, Chief Marketing Officer, and Chief Sales Officer. The team has been advised to only expand as each role becomes necessary, and only when suitable resources are available. As such, the need for team expansion will be assessed on an ongoing basis. 


\section{CHAPTER 4: MARKET RESEARCH, CONSUMERS}

\subsection{Timeline}

Table 2. Market research, consumers: Timeline of key milestones and activities

\begin{tabular}{|l|l|}
\hline DATE & ACTIVITIES \\
\hline 3-7 March 2014 & $\begin{array}{l}\text { Alex completes first draft of consumer survey, with feedback } \\
\text { and input from Puneeth and Michael Elwood-Smith. }\end{array}$ \\
\hline 10-21 March 2014 & $\begin{array}{l}\text { Alex conducts initial testing of consumer survey, with students, } \\
\text { academics, and people from within Wellington's start-up } \\
\text { community. }\end{array}$ \\
\hline 24 March to 13 April & $\begin{array}{l}\text { Alex launches the online survey, and distributes with the } \\
\text { assistance of Puneeth. Alex conducts face-to-face interviews. }\end{array}$ \\
\hline 14-18 April 2014 & Alex undertakes preliminary data analysis. \\
\hline 19-30 May 2014 & Alex completes full data analysis. \\
\hline
\end{tabular}

\subsection{Survey findings}

High-level summary:

- Bundling emerged as the most popular monetisation strategy amongst consumers.

○ Overall, only $0.5 \%$ of consumers said that they would definitely purchase a subscription to a single New Zealand news website.

- For a national package of all news sites, $1.4 \%$ (2.8x increase).

○ For a global package of all news sites, $6.6 \%$ (13x increase).

- For a global news package bundled with music and video, $12.5 \%$ (25x increase).

- 18-30 year olds are the least likely age group to purchase a single New Zealand news website, however they are the most likely to purchase a global package of news.

○ Nobody between the ages of 18-30 said that they would definitely purchase a subscription to a single New Zealand news website. 
○ $11.9 \%$ said that they would definitely purchase a global package of news websites (1.8x overall average).

- The perceived quality of journalism is one of the most important factors when consumers choose whether or not to pay for news.

The team's survey of 457 newsreaders was undertaken from March-April 2014, and assessed people's willingness to pay for ten online monetisation strategies, as detailed in Table 3.

Table 3. Monetisation strategies explored within survey

\begin{tabular}{|c|c|}
\hline STRATEGY & DESCRIPTION \\
\hline Pay-per-article & A small fee to access each article. \\
\hline Standalone subscription & $\begin{array}{l}\text { A monthly subscription for unlimited access to one New } \\
\text { Zealand news website. }\end{array}$ \\
\hline National package & $\begin{array}{l}\text { A monthly subscription for access to all news websites in New } \\
\text { Zealand. }\end{array}$ \\
\hline Global package & $\begin{array}{l}\text { A monthly subscription for access to all news websites in the } \\
\text { world. }\end{array}$ \\
\hline $\begin{array}{l}\text { News }+ \text { multimedia } \\
\text { package }\end{array}$ & $\begin{array}{l}\text { A monthly subscription for access to all news websites in the } \\
\text { world, as well as music, television and movies. }\end{array}$ \\
\hline Crowdfunding & $\begin{array}{l}\text { Journalists pitch story ideas, and readers donate funds } \\
\text { towards the creation of a specific story. }\end{array}$ \\
\hline Donations & $\begin{array}{l}\text { Readers donate funds to a particular journalist or news } \\
\text { organisation to support their operations. }\end{array}$ \\
\hline Mobile application & $\begin{array}{l}\text { A monthly subscription for access to a mobile news } \\
\text { application, available on phones or tablets. }\end{array}$ \\
\hline Fee to remove advertising & $\begin{array}{l}\text { A monthly subscription to remove advertising from news } \\
\text { websites. }\end{array}$ \\
\hline Premium content & $\begin{array}{l}\text { A 'freemium' model, where general news articles remain free } \\
\text { but readers pay a monthly fee for access to premium stories. }\end{array}$ \\
\hline
\end{tabular}

The survey findings revealed that consumers' willingness to pay for news increases considerably when readers can subscribe to a package of content from multiple providers (Figure 6). If news organisations around the world participate in subscription packages, they will significantly increase the number of paying subscribers. 


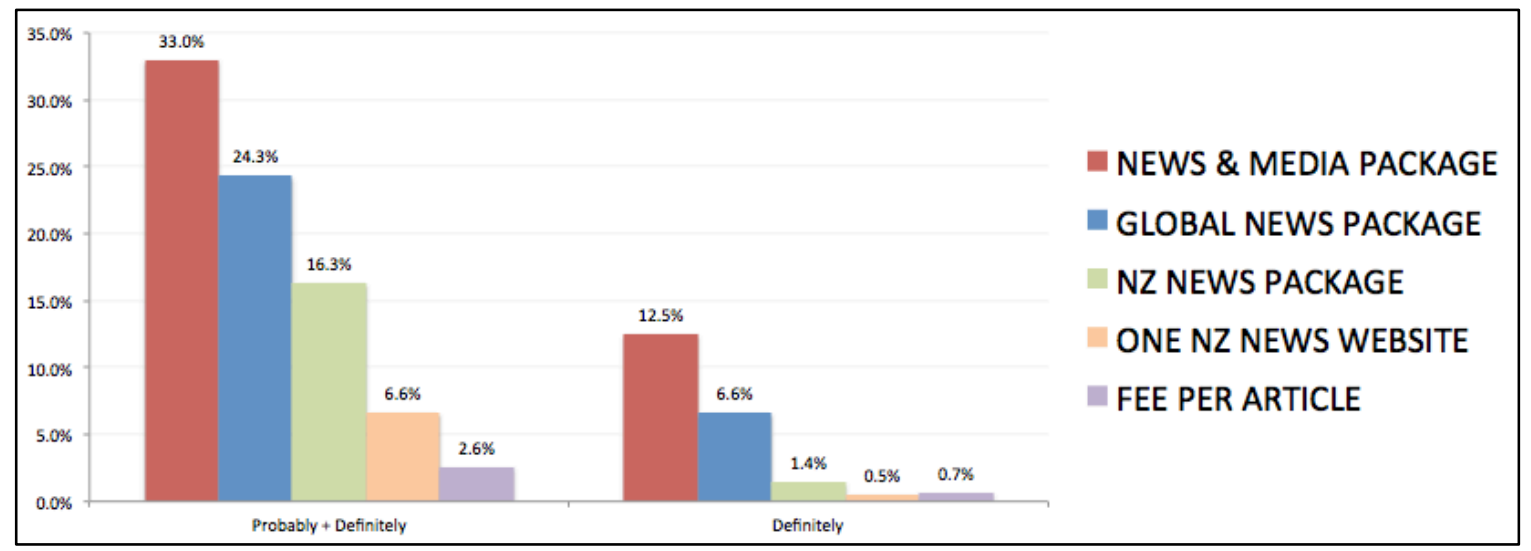

Figure 6. Willingness to pay for news at different levels of packaging

Overall, the least popular payment option was paying a fee to access each article. An aggregate of $2.6 \%$ of respondents said that they would probably or definitely pay for news under this model, while only $0.7 \%$ said that they would definitely pay.

Slightly ahead of payment-per-article was the option of a standalone subscription, for unlimited access to one New Zealand news website by itself. An aggregate of $6.6 \%$ of respondents said that they would probably or definitely pay for this option, while only $0.5 \%$ said definitely.

The popularity of a national news package, containing all journalism websites in New Zealand was substantially more popular than a standalone subscription. An aggregate of $16.3 \%$ of respondents said that they would probably or definitely pay for this option, while $1.4 \%$ said definitely.

A global news package was the most popular of all news-only options presented to respondents. An aggregate of $24.3 \%$ of respondents said that they would probably or definitely pay for this option, while $6.6 \%$ said definitely.

Respondents were most willing to pay for a global multimedia package, containing news, music, television and movies. An aggregate of 33\% of respondents said that they would probably or definitely pay for this option, while $12.5 \%$ said definitely. 
Our survey also revealed that bundling significantly increases the propensity to pay within 18-30 year olds (see Figure 7). Under a standalone subscription strategy, 18-30 year olds are the least likely demographic to purchase news. Out of 134 respondents, nobody said that they would definitely purchase one New Zealand news website by itself.

Under a bundled subscription strategy, however, 18-30 year olds become the most likely age group to purchase news. For a global news package, $11.9 \%$ said that they would definitely pay. For a news and multimedia package, $23 \%$ said that they would definitely pay. For each of these packages, 18-30 years are nearly twice as willing to definitely pay than the overall average.

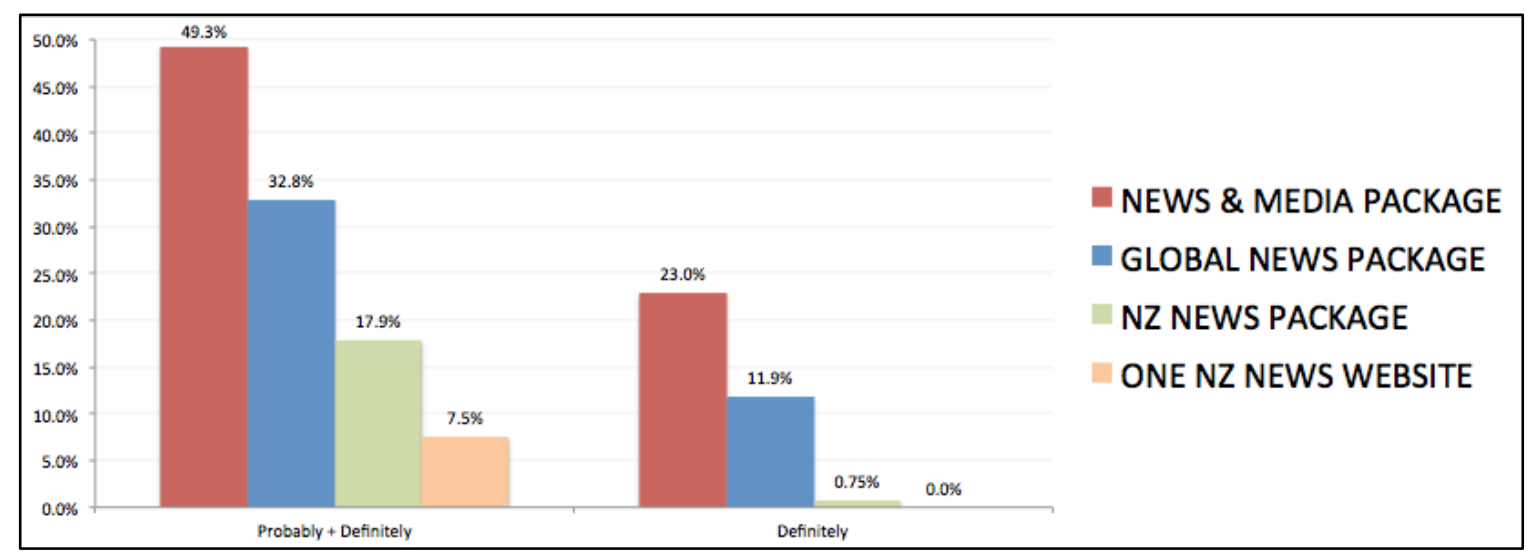

Figure 7. Willingness to pay, 18-30 year olds

We also looked at consumer's willingness to pay for news under alternative monetisation models. Multimedia bundling was more popular than all other strategies explored within the survey, and emerged as a clear winner, closely followed by global news bundling (see Figure 8). 


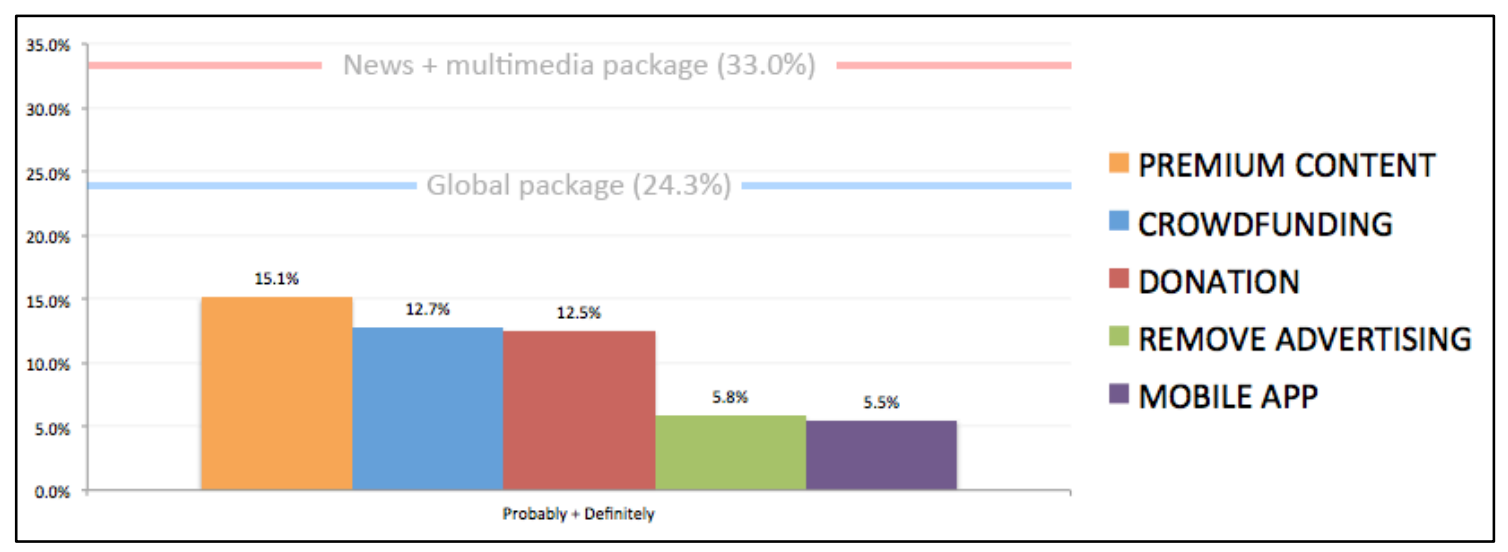

Figure 8. Willingness to pay for news under alternative funding strategies

Out of the alternative strategies explored, a premium content strategy was most popular, with $15.1 \%$ of respondents indicating that they would probably or definitely purchase. Qualitatively, many respondents expressed that they would not pay for journalism unless the content was of high quality. This finding highlights the importance of producing premium journalism, regardless of the funding strategy pursued.

Donations (12.7\%) and crowdfunding (12.5\%) were also popular among respondents, and should be considered as strong alternatives for raising additional revenue. Qualitatively, there was widespread enthusiasm for the direct support of journalism through voluntary donations. Some respondents, however, expressed concerns that having writers beholden to donations could undermine the independence of journalism.

A subscription fee to remove advertising (5.8\%) was one of the least popular funding methods. While it may appeal to a niche category of readers, it is unlikely to provide substantial revenue. Furthermore, some respondents indicated that they enjoy advertisements when they promote products or services they are interested in. Others highlighted that they simply use products such as AdBlock ${ }^{4}$ to achieve the same outcome for free.

${ }^{4}$ AdBlock is a free web browser plugin that allows users to block advertising within websites. 
A subscription to a mobile news app $(5.5 \%)$ was the least popular alternative strategy. In hindsight, this survey question was inadequate to properly explore this strategy. The phrasing only explored respondents' general willingness to pay, without specific reference to features and functionality. There are a wide variety of mobile news applications, each with their own unique functionality, and further research is needed to assess willingness to pay within this category.

\subsection{Identifying the best funding strategy for PressPass}

The survey findings directly influenced the registration options selected for the PressPass platform. Below is a brief overview of each option, as well as its role within PressPass' overall funding strategy. Note that registration options could be dropped or added prior to launch, depending on negotiations with publishers. Furthermore, some options could be added after launch. In particular, a global multimedia package could be added if negotiations are successful with online subscription services such as Netflix and Spotify (see Section 4.4 for further details).

\section{Registration options}

When registering, users can choose to either have a free account, or pay for a subscription to one publication, a national package, or a global package. Each of these options has strategic importance to news organisations and the success of PressPass.

1) Free account: A free account brings readers into the sales pipeline, providing an opportunity to nurture a direct relationship while promoting the benefits of a subscription. Registration details also provide valuable demographic insights, allowing websites to earn more revenue from display advertising.

2) Standalone subscription: The option to subscribe to a single news site allows publishers to maintain a standalone strategy, while experimenting with a bundled ecosystem. Furthermore, some readers would prefer a standalone subscription. Within our survey, $14 \%$ of respondents preferred a single site over a global package, mostly readers from older demographics. 
3) National PressPass: Our survey revealed that $15 \%$ of respondents would prefer a national package over a global package. By providing a national package as an option, we will be able to more effectively cater to consumer preferences and maximise the number of successful conversions.

4) Global PressPass: The global package was by far the most popular news option within our survey, and has the highest potential for success. The number of respondents willing to definitely pay for a global package was 13 times greater than a standalone subscription, and nearly five times greater than a national package. 


\subsection{Customer acquisition strategy}

High-level summary:

- Integration with existing news websites provides PressPass with a direct marketing channel to connect with large marketplaces of loyal news consumers.

- PressPass' free registration option is an important lead generator for connecting with news consumers, who can be upsold to a national or global package through targeted marketing campaigns.

- News partners have a direct financial incentive to promote the PressPass platform, due to a conversion commission where they receive $20 \%$ of revenue from each customer who subscribes to a package via their website.

- $\quad$ PressPass will pursue mutually beneficial partnerships with ISPs and media streaming services, with cross-promotional deals to bundle PressPass with their offerings.

- PressPass will promote its service via traditional outlets such as print, radio and television, as well as online via Google AdWords, Facebook Ads, and using techniques such as SEO and content marketing.

- PressPass aims to convert a minimum of $2.5 \%$ of readers within 6 months, $5 \%$ within 12 months, and 10\% within 24 months.

By integrating with existing news websites, PressPass gains a direct marketing channel to connect with large audiences of loyal readers. Whenever a reader visits a partner news website, the PressPass platform will be prominently visible along the top of the webpage. Furthermore, as soon as a reader reaches their monthly limit of free articles, they will be prompted to create a subscription account using the PressPass platform.

At this stage, readers may choose to create a free account for additional page views. A free account brings readers into the sales pipeline, providing PressPass with a valuable opportunity to implement a targeted marketing campaign based on each user's unique demographic traits. This is likely to be one of the platform's most prominent customer acquisition strategies.

News partners will also have financial incentives to convert their readers into paying subscribers. The most direct incentive is a $20 \%$ conversion commission, paid to each news partner whenever they convert a reader to the national or global package. News 
partners also receive royalty payments whenever a subscriber visits their website, creating further inventive to maximise the number of conversions. (See Section 10.1 for further details).

Once partnerships have been established with news organisations, PressPass will seek to develop mutually beneficial partnerships with other online media providers such as Spotify, Pandora, Netflix, Lightbox and Neon. By bundling with music and video content, PressPass will be able to further increase the number of readers willing to pay for news, particularly amongst the 18-30 year old demographic. For music and video providers, PressPass will be able to provide a direct channel to older demographics that are difficult to reach with online streaming services.

PressPass is also considering partnerships with Internet Service Providers (ISP) such as Spark, Slingshot and Orcon. There are a number of ways that these partnerships could function. One, is to have ISP customers receive a free PressPass account when paying for a particular internet plan. This approach is similar to Spark's partnership with Spotify, where some mobile plans include a free Spotify subscription. Other possibilities include a free trial, or a promotional discount code offered to ISP customers.

In addition to the customer acquisition strategies outlined above, PressPass plans to run a promotional campaign across print, radio, television and online. Online strategies include a the use of Google AdWords, Facebook Ads, and mobile display advertising, as well as SEO optimisation and content marketing.

Customer acquisition targets:

$-2.5 \%$ of readers within 6 months

$-5 \%$ of readers within 12 months

$-10 \%$ of readers within 24 months 


\subsection{Target consumers}

High-level summary:

- $\quad$ PressPass' target consumers include

○ $\quad 18-30$ year-olds

- Readers with an income above $\$ 80,000$

o Readers who visit more than four news websites each week

○ Readers who visit news websites several times per day

○ Readers who mostly visit international news websites

- Readers with an interest in finance, business and politics

Survey data revealed that there are a number of demographic traits that correlate with an increased propensity to pay for a global package. By identifying these traits, PressPass will be able to better target consumers with tailored promotional campaigns that maximise their rate of conversion.

\section{Age}

Readers between the ages of 18 and 30 are most likely to pay for a global news package, and will provide the highest rate on return when targeted with marketing campaigns (Figure 9).

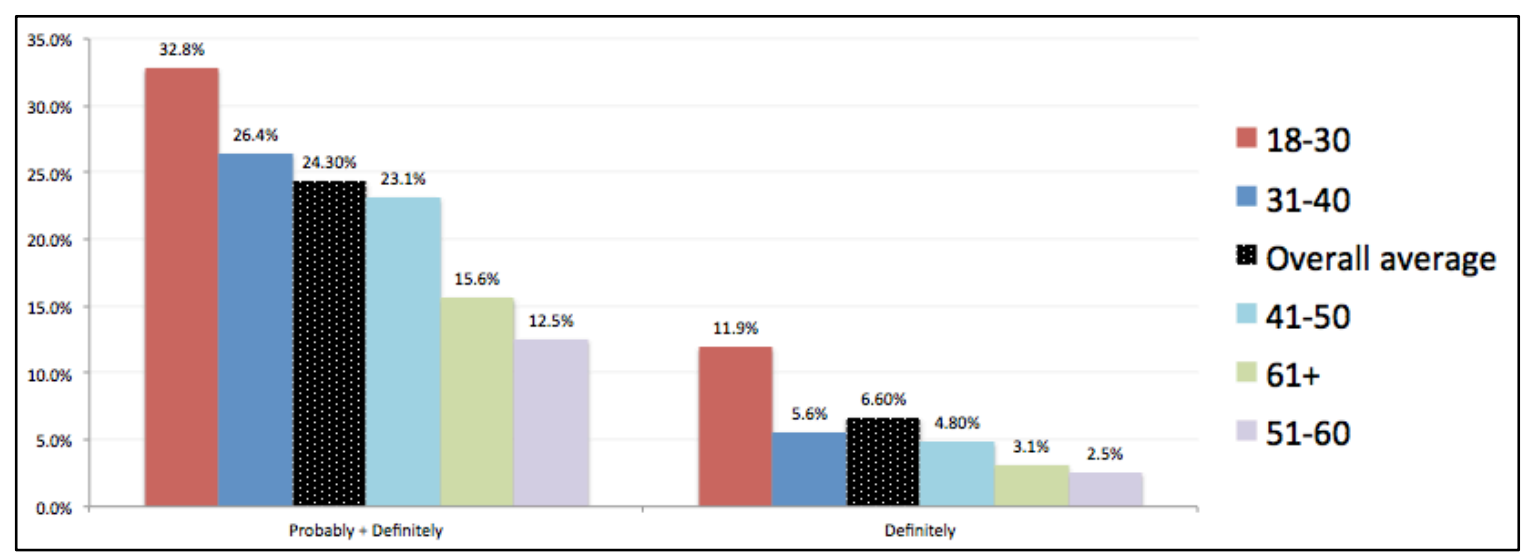

Figure 9. Willingness to pay for a global news package (age) 


\section{Income}

Those with an income over $\$ 80,000$ are most likely to probably or definitely purchase a global package. This is presumably due to their higher disposable income. Interestingly, those with an income between $\$ 15-40,000$ are the most likely to definitely purchase a global package. This may be due to this income group containing a higher proportion of respondents within the 18-30 year old demographic (Figure 10).

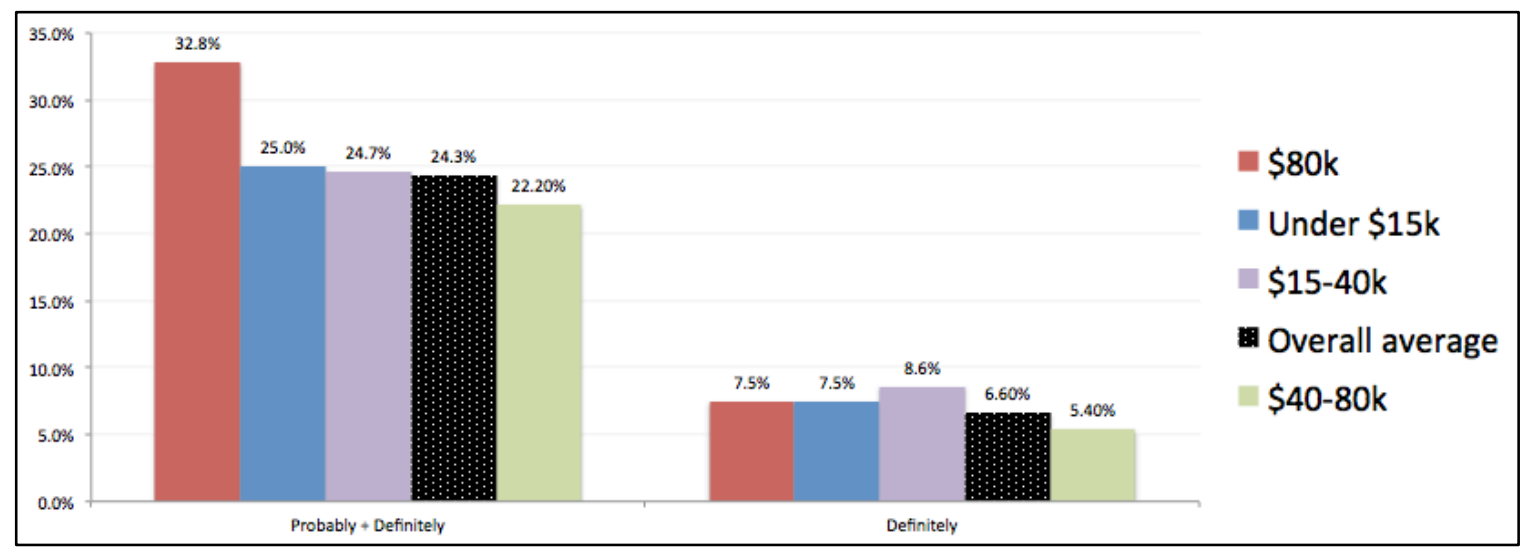

Figure 10. Willingness to pay for a global news package (income)

\section{Engagement with news websites}

Consumers who visit more than 10 news websites each week are more than twice as likely to say that they'd definitely purchase a global package, very closely followed those who visit 4-10 websites per month (Figure 11). Consumer's propensity to pay is also highest if they visit news sites several times per day (Figure 12), and if they spend most of their time reading international news websites (Figure 13). Those consumers who are most interested in business and politics, also have a substantially higher propensity to pay than those who prefer other topics (Figure 14). 


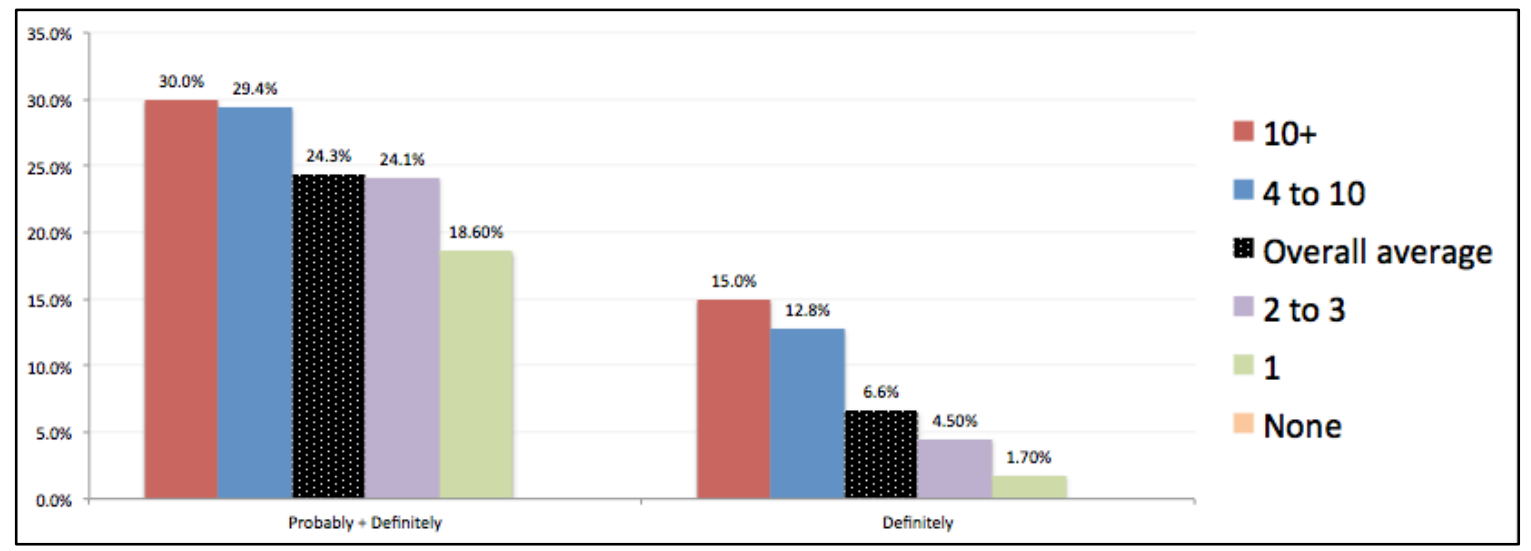

Figure 11. Willingness to pay for a global news package (number of news sites visited each week)

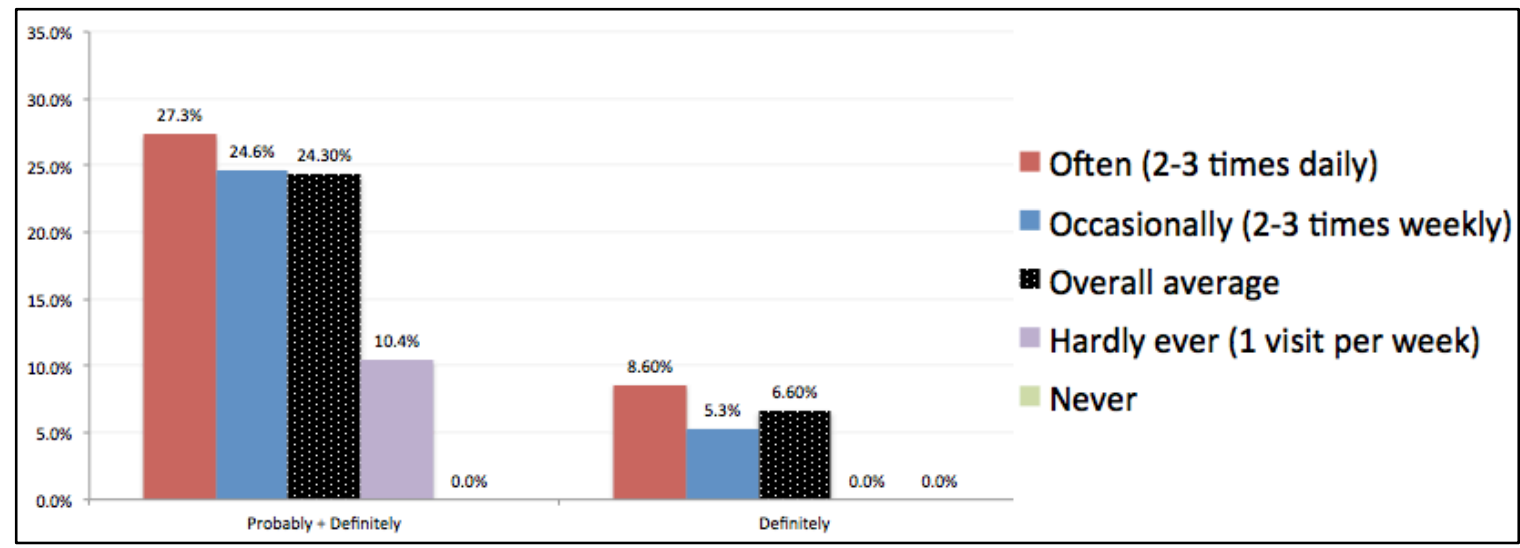

Figure 12. Willingness to pay for a global news package (frequency of visits)

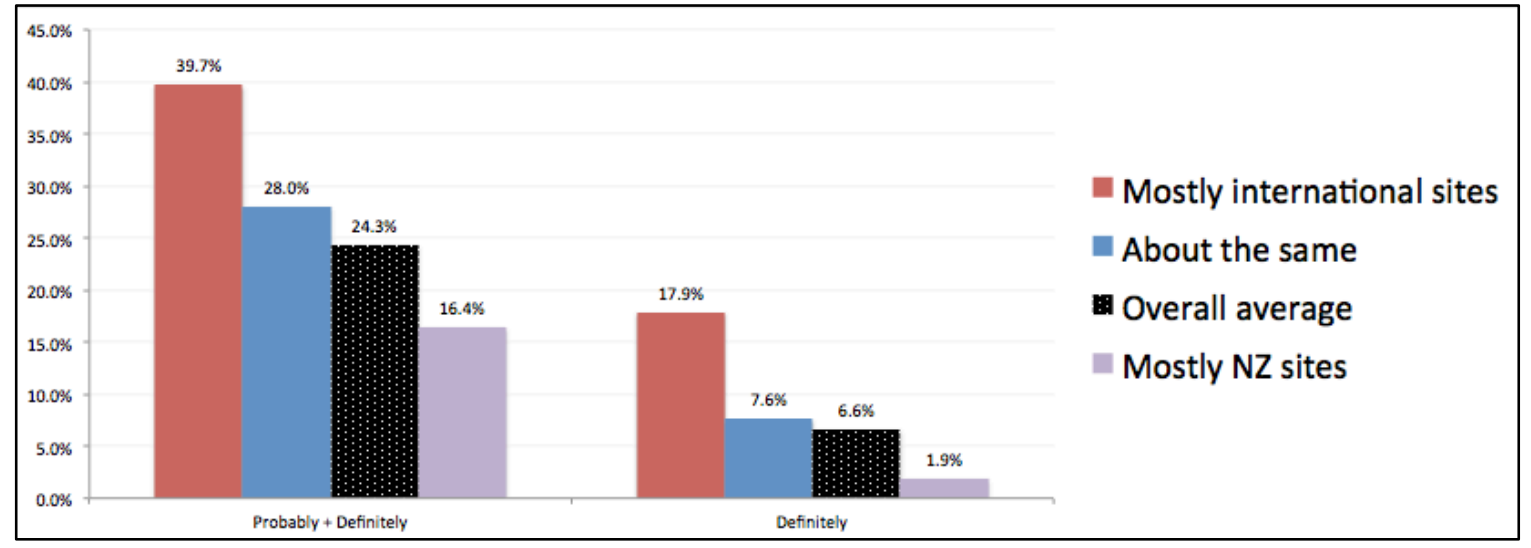

Figure 13. Willingness to pay for a global news package (proportion of time spent reading New Zealand sites versus international) 


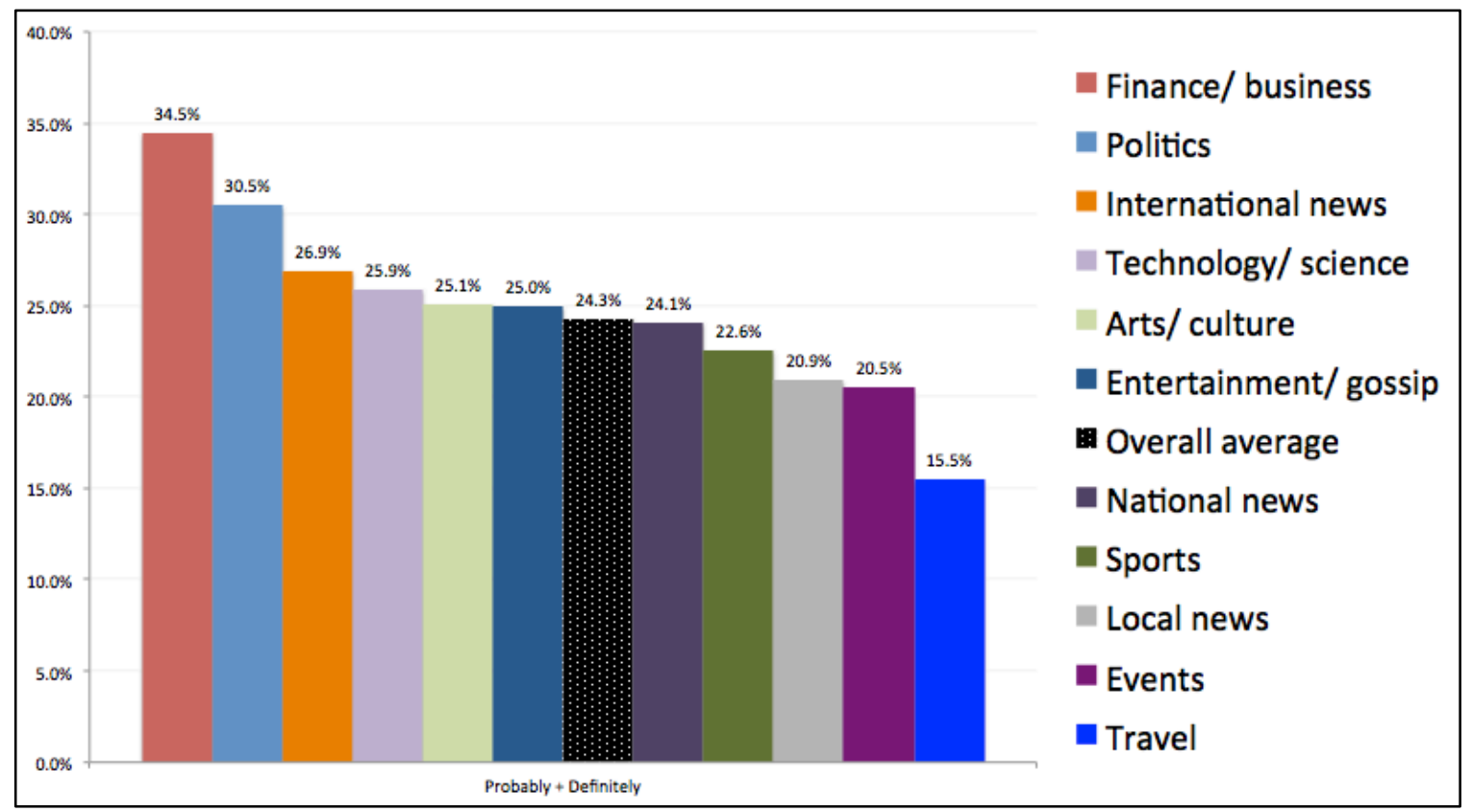

Figure 14. Willingness to pay for a global news package (type of news read most often)

\section{Media purchasing habits}

Those who already have an online video subscription are nearly three times as likely to to definitely purchase a global subscription, while those with an online music subscription are nearly twice as likely (Figure 15). It is likely that this increased propensity to pay aligns with the younger demographic that typically purchases online subscriptions. Furthermore, those with online subscriptions are familiar with the "payonce-access-all' model of bundling. This particular finding strongly supports the strategy of partnering with services such as Spotify and Netflix, as outlined in Section 4.4 .

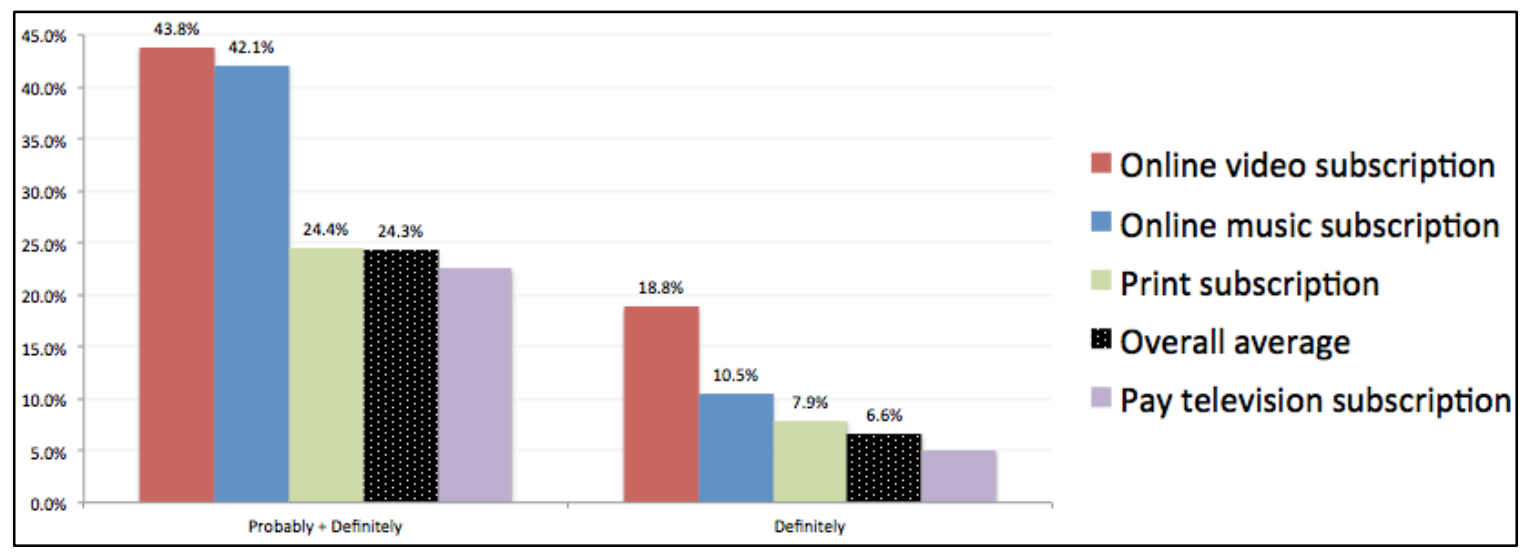

Figure 15. Willingness to pay for a global news package (current media purchases) 


\section{CHAPTER 5: MARKET RESEARCH AND PARTNERSHIP DEVELOPMENT, NEWS ORGANISATIONS}

\section{$5.1 \quad$ Timeline}

Table 4. Market research, news organisations: Timeline of key milestones and activities

\begin{tabular}{|c|c|}
\hline DATE & ACTIVITIES \\
\hline 2 June 2014 & $\begin{array}{l}\text { Alex has a phone interview with an executive at Radio New } \\
\text { Zealand. }\end{array}$ \\
\hline 6-10 August 2014 & Auckland trip: Alex has $3 x$ meetings with NZME. \\
\hline 20-21 August 2014 & $\begin{array}{l}\text { Auckland trip: Alex has } 1 x \text { meeting with TVNZ, } 1 x \text { meeting with } \\
\text { MediaWorks. }\end{array}$ \\
\hline $\begin{array}{l}24 \text { August to } \\
6 \text { October }\end{array}$ & $\begin{array}{l}\text { USA trip: Alex has } 3 x \text { meetings with the New York Times, } 4 x \\
\text { meetings with the Economist, } 1 x \text { meeting with National } \\
\text { Geographic. }\end{array}$ \\
\hline 8-10 October 2014 & $\begin{array}{l}\text { Auckland trip: Alex has } 1 x \text { meeting with TVNZ, } 1 x \text { meeting with } \\
\text { MediaWorks. }\end{array}$ \\
\hline $\begin{array}{l}22-24 \text { October } \\
2014\end{array}$ & $\begin{array}{l}\text { Auckland trip: Alex has } 2 x \text { meetings with NZME, } 1 x \text { meeting with } \\
\text { MediaWorks. }\end{array}$ \\
\hline $\begin{array}{l}20-21 \text { November } \\
2014\end{array}$ & Auckland trip: Alex has 1x meeting with TVNZ \\
\hline
\end{tabular}

\subsection{Partnership development activities}

High-level summary:

- In New Zealand, Alex conducted several meetings with senior management within NZME, TVNZ and MediaWorks.

- In the USA, Alex met with senior management within the New York Times, the Economist, and National Geographic. 
- Feedback about the prototype was positive, particularly regarding the way it provides news organisations with full control over editorial decisions, layout and advertising.

- News organisations desired an intermediary platform that was fair, equitable and transparent. This feedback helped shape the principles that guide the PressPass platform.

- Some key aspects of the platform that require further negotiation include: pricing, commission structure and royalty distribution.

- For US news websites, a launch of PressPass in NZ provides a low-risk opportunity to assess the benefits of bundling.

- For NZ news websites, partnering with PressPass provides an opportunity to launch their paywalls with a world-leading strategy.

Between June and November 2014, Alex met with NZME, TVNZ, MediaWorks, the New York Times, the Economist, and National Geographic. He met with a total of 26 employees in senior management positions, who had input into each news organisation's monetisation strategy. Within each organisation, Alex met with senior managers who had responsibility for strategy, marketing, revenue, consumer research, digital content, new products and technology. Table 5 provides a full overview of each employee's role, seniority and primary responsibility within the organisation.

Table 5. Roles of interviewees within news organisations

\begin{tabular}{|l|l|l|}
\hline ROLE & SENIORITY & $\begin{array}{l}\text { PRIMARY RESPONSIBILITY } \\
\text { (number of people) }\end{array}$ \\
\hline $\begin{array}{l}\text { Research and Insights; } \\
\text { Strategy and Analytics; } \\
\text { Research and Analytics; } \\
\text { Strategy }\end{array}$ & Head; Director; & $\begin{array}{l}\text { Conducting consumer research, } \\
\text { and using insights to inform } \\
\text { strategy. } \\
\text { (four people) }\end{array}$ \\
\hline $\begin{array}{l}\text { Digital Content; Digital Media; } \\
\text { Digital; Online Content }\end{array}$ & $\begin{array}{l}\text { Head; Group Director; } \\
\text { General Manager; } \\
\text { Executive Producer; } \\
\text { Group Editor }\end{array}$ & $\begin{array}{l}\text { Coordinating and maintaining } \\
\text { digital content. } \\
\text { (five people) }\end{array}$ \\
\hline $\begin{array}{l}\text { Marketing; Digital Marketing; } \\
\text { Circulation Innovation }\end{array}$ & Head; Director & $\begin{array}{l}\text { Promoting the uptake of } \\
\text { content offerings. } \\
\text { (four people) }\end{array}$ \\
\hline News and Current Affairs & $\begin{array}{l}\text { Head; Editor of Content; } \\
\text { Director; Deputy } \\
\text { Director; }\end{array}$ & $\begin{array}{l}\text { Coordinating the creation of } \\
\text { editorial content. } \\
\text { (four people) }\end{array}$ \\
\hline
\end{tabular}




\begin{tabular}{|c|c|c|}
\hline $\begin{array}{l}\text { Technology; Product; Product } \\
\text { Management, Digital } \\
\text { Solutions; New Initiatives; } \\
\text { Business Development and } \\
\text { Innovation }\end{array}$ & $\begin{array}{l}\text { CTO; Executive Director; } \\
\text { Vice President; Assistant } \\
\text { Managing Editor; }\end{array}$ & $\begin{array}{l}\text { The creation and } \\
\text { implementation of new } \\
\text { products and innovations. } \\
\text { (five people) }\end{array}$ \\
\hline $\begin{array}{l}\text { Revenue; Finance and } \\
\text { Operations }\end{array}$ & $\begin{array}{l}\text { Group Head; Vice } \\
\text { President }\end{array}$ & $\begin{array}{l}\text { Oversight of organisational } \\
\text { revenue strategy. (two people) }\end{array}$ \\
\hline Chief Executive Officer & CEO & $\begin{array}{l}\text { Decision-making responsibility } \\
\text { for organisation. (two people) }\end{array}$ \\
\hline
\end{tabular}

The individuals that Alex met within these organisations agreed that global bundling is a promising strategy for the industry to consider. When shown the prototype, they provided positive feedback about the way it easily integrates with existing websites and provides full control over editorial and advertising. Furthermore, they liked the ability to maintain direct relationships with their readers, rather than being side-lined by a central aggregator. One of the biggest fears of news organisations was losing control to a third-party intermediary, and the decentralised nature of the PressPass platform allayed many of these fears.

News organisations also expressed a desire for robust reassurances that the intermediary would be fair, equitable and transparent. This helped shape the core principles guiding the project, which include: platform independence, non-exclusivity, open source development, and a commission structure that includes rebates for news partners. These principles are explained in greater depth within Section 5.3, and form part of our competitive strategy.

Aspects of the platform that require further negotiation include: determining the method used to set pricing for the national and global packages, negotiating the commission structure, and determining the exact method used for royalty distribution. Our current strategy for finding a suitable solution is outlined within Section 10.2.

While discussions are still at an early-stage, there has been significant interest in trialing the PressPass platform within the NZ market. American publishers were particularly interested in having the opportunity to assess the benefits of bundling, without risking the cannibalisation of their existing strategy within the USA. For New Zealand 
publishers, many were enthusiastic about the prospect of leading the journalism industry by adopting the best monetisation strategy available.

PressPass' current focus is on converting initial interest in the PressPass platform into formalised commitments. Since New Zealand news organisations are continuing to delay their premium-content strategy, it has been difficult to develop firmer commitments.

\subsection{Competitive strategy}

There are a handful of companies attempting to improve the way that news is monetized online. Each company has developed a platform that has its own strengths and weaknesses. However, none have yet implemented a monetization strategy that sufficiently offsets the ongoing losses from print revenue. A competitive analysis of our strongest competitors has been provided within Table 6 (page 46), with a brief summary below.

\section{Competitive overview}

Piano Media: Provides national paywalls within Slovenia, Slovakia and Poland. Integrates with existing news sites, providing a universal login account that unlocks all partner sites for one monthly fee.

Press +: Provides standalone paywall infrastructure to over 600 news websites, mostly within Europe and the USA. Integrates with existing news sites, and charges separately for access to each site.

Blendle: Provides a web browser and tablet application with pay-per-view access to articles from nearly all publishers in the Netherlands, as well as some international partners.

Inkl: Provides a mobile website that allows subscribers to pay one fee to access news from all publishing partners. 
TinyPass: A monetisation platform that integrates with existing websites, allowing news organisations to either establish a standalone paywall or to charge pay-per-view access to individual articles.

\section{Competitive advantage}

The key competitive strengths of our platform are summarized below. Our publisher interviews revealed a strong mistrust of intermediaries, and a fear they will gain excessive dominance over the journalism ecosystem. PressPass strengthens its trustworthiness by being independent, open source, low cost and non-exclusive. These principles help provide PressPass with a competitive advantage over the alternative monetisation platforms available to news organisations.

Low commission: We will charge zero commission for subscriptions to a single website, which is lower than any of our competitors. We will charge only $20 \%$ for subscriptions to our global package, and will further cut our commission as profit margins increase. Our competitors' rates: Press $+20 \%$ (standalone), Piano 30\% (national bundle), Blendle 30\% (pay-per-article), TinyPass (tiered structure, see Table 6), Ink1 (data unavailable).

Open Source: When the PressPass platform is launched, it will be released under an open source license. Existing platforms are proprietary, resulting in a power imbalance between the journalism community and intermediaries. By adopting open source, the journalism community will be able to see how the PressPass code works, verify its security, and expand upon its core functionality. Our platform will also be interoperable with other platforms and services.

Independence: Most existing platforms have links with particular news organisations, while some publishers have direct ownership stakes. Feedback from news organisations suggests that competitive rivalries will hinder efforts to create an all-inclusive universal package, if direct publisher ownership exists. Furthermore, many publishers fear that conflicts of interest could arise as a result of direct ownership. PressPass' independence allows the platform to work across competitive boundaries, in the interests of the entire journalism community 
Non-exclusive: All publishing partners are welcome to use alternative platforms that complement or compete with PressPass. By avoiding exclusivity, PressPass is committed to facilitating a highly competitive journalism ecosystem. While competitors have not yet imposed exclusivity on their partners, some news organisations expressed a fear that exclusivity could be adopted as market power grows.

Multiplatform focus: Monetization strategies need to focus on web, mobile and tablet platforms to reach their full potential. Currently, only Blendle has a multiplatform strategy. PressPass plans to develop mobile applications that complement its web offering.

Best strategy: A universal bundle has emerged as the best strategy within the PressPass team's survey, with $6.6 \%$ of consumers saying they would definitely pay for a global package. Standalone subscriptions (Press + , TinyPass) were the least popular option at 0.5\%. Paying-per-article (Blendle, Tiny Pass) was 0.7\%. National packages (Piano Media) was $1.4 \%$. 
Table 6. Competitive landscape

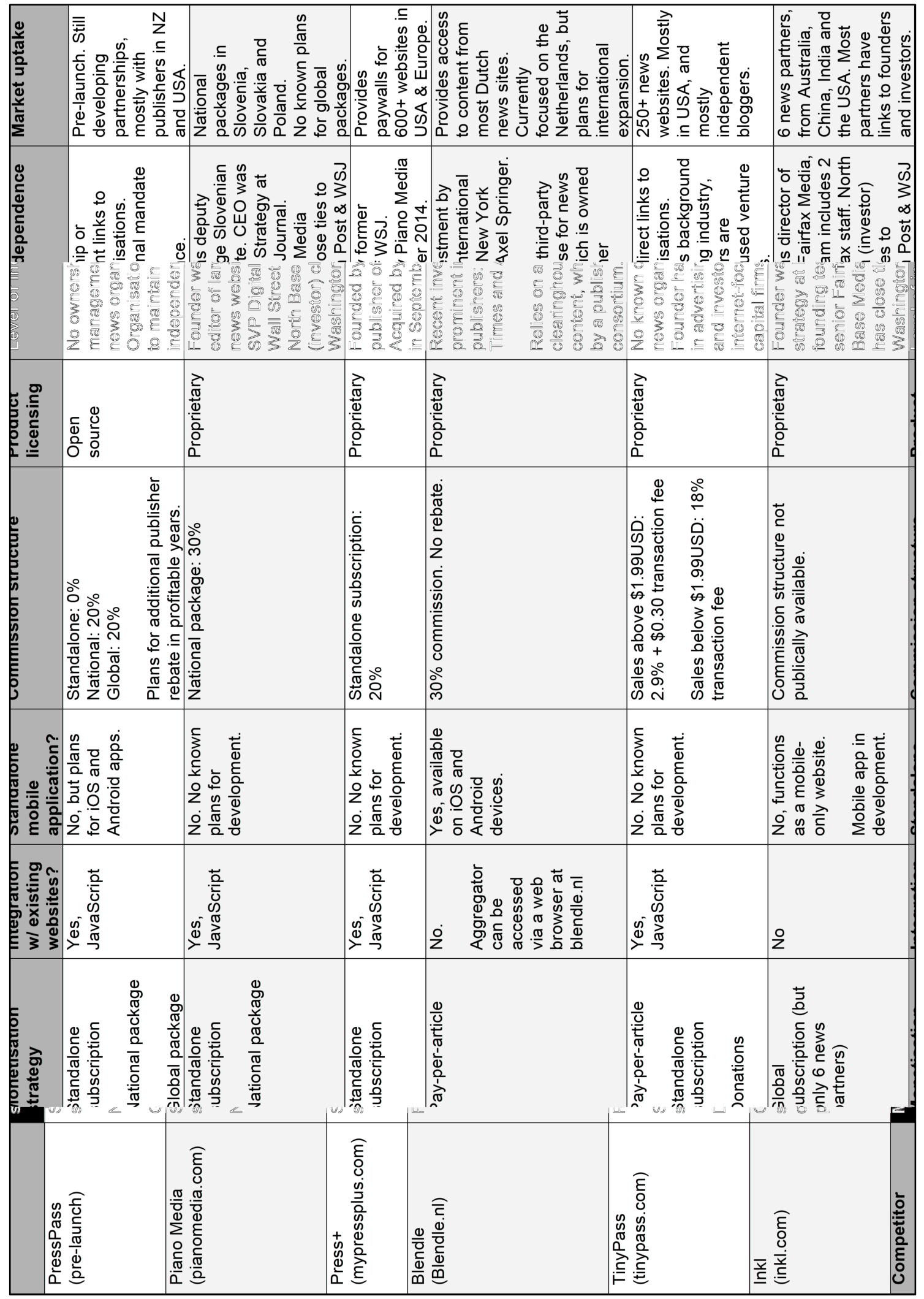




\section{CHAPTER 6: PRODUCT DEVELOPMENT}

\subsection{Timeline}

Table 7. Product development: Timeline of key milestones and activities

\begin{tabular}{|c|c|}
\hline DATE & ACTIVITIES \\
\hline March & $\begin{array}{l}\text { Specifications: Initial specifications document written by Alex and sent to } \\
\text { Puneeth on March } 18^{\text {th }} \text {. Puneeth's development work was initially limited to } \\
\text { basic mock-ups that could be used for demonstrative purposes, but had } \\
\text { minimal functionality. This was so that market research could be used to } \\
\text { validate key assumptions, before investing team resources into full } \\
\text { development. } \\
\text { Demo website: Puneeth creates an early demonstration website, using } \\
\text { 'iframes' to illustrate proposed functionality of the PressPass ribbon. }\end{array}$ \\
\hline April to May & $\begin{array}{l}\text { Prototype development: Puneeth begins early development work on } \\
\text { PressPass ribbon and styles, using the Jquery framework. Prototype is } \\
\text { integrated with a WordPress website for demonstration purposes. }\end{array}$ \\
\hline June & $\begin{array}{l}\text { Login: Login functionality implemented by Puneeth, using Facebook's social } \\
\text { sign-on API. The code was refracted to accommodate integration with } \\
\text { multiple social media sign-on providers. Skeleton design pattern was } \\
\text { updated to implement this functionality. } \\
\text { Analytics: Puneeth and Alex meet with the founder of Piwik, as well as its } \\
\text { lead developer. Piwik is an open source analytics platform that is integrated } \\
\text { with PressPass. The meeting provided an opportunity to discuss ways to } \\
\text { adapt the code to meet PressPass' requirements. } \\
\text { Version control: Puneeth moved the source code to Github Source Control } \\
\text { in mid-June. This was done in preparation for Paul Smith joining PressPass, } \\
\text { and allowed the development team to better manage the source code. }\end{array}$ \\
\hline July & $\begin{array}{l}\text { Specifications: Updated specifications document written by Alex, and sent } \\
\text { to Puneeth and Paul on July } 3 \text {. New specifications were based on the full } \\
\text { analysis of customer interviews, as well as early feedback from the } \\
\text { journalism community. Updated specifications outlined product } \\
\text { functionality in more depth, and provided a timeline with clear milestones. } \\
\text { Analytics: Puneeth installs the PIWIK web analytics software on the server, } \\
\text { allowing it to be enabled on the demonstration sites. In addition to the } \\
\text { standard installation, the code needed to be modified to allow for easier } \\
\text { integration with the websites of future news partners. } \\
\text { Payment: Puneeth integrates a sandboxed version of PayPal with the } \\
\text { registration process. } \\
\text { Design and layout: Paul refined the style sheet for the ribbon to improve } \\
\text { consistency across different browsers. }\end{array}$ \\
\hline
\end{tabular}




\begin{tabular}{|l|l|}
\hline DATE & ACTIVITIES \\
\hline August & $\begin{array}{l}\text { Specifications: Updated specifications were provided to Puneeth and Paul } \\
\text { on July } 20^{\text {th }} \text {, with a focus on improving the code ready for Alex's meetings } \\
\text { with news organisations in Auckland and the USA. Specifications were } \\
\text { largely focused on refinements to design and user interface. } \\
\text { Demo websites: Puneeth made more sample WordPress sites live on the } \\
\text { server. These sample websites were integrated with the PressPass ribbon for } \\
\text { testing and demonstration purposes. } \\
\text { Privacy: Alex has meetings with the Lead Privacy Engineer at Mozilla, as well } \\
\text { as the Technology Projects Director and Technology Operations Director at } \\
\text { the Electronic Frontier Foundation. Discuss technical solutions that will } \\
\text { enable data collection while respecting user privacy. PressPass team decides } \\
\text { that hash encryption of data will be best approach when this functionality is } \\
\text { first implemented, with more complex solutions considered at a later stage. } \\
\text { Code refinement: Puneeth and Paul continued work to refine the code, } \\
\text { improve design elements, remove glitches, minimise loading time, and other } \\
\text { miscellaneous tasks that arose during the development process. }\end{array}$ \\
\hline September & $\begin{array}{l}\text { Cross-domain storage: Two features from the specifications document were } \\
\text { particularly difficult to implement, and required the novel solution of cross- } \\
\text { domain storage. These features were: } \\
\text { 1) To recognise the number of free articles read by anonymous users, } \\
\text { cumulatively across all of the partner news websites. Once the quota of free } \\
\text { articles was reached, the paywall would be triggered. } \\
\text { 2) To enable persistent login across all partner websites. Once signed in, a } \\
\text { user would be automatically logged into any partner website that they } \\
\text { visited. } \\
\text { As a solution, Paul and Puneeth implemented cross-domain storage, which } \\
\text { uses 'iframes' and an HTML5 client storage feature to enable this } \\
\text { functionality. This solution is similar to the method followed by Google, } \\
\text { Facebook and Microsoft. } \\
\text { Server: Meteor and MongoDb were used to develop the server side of the } \\
\text { PressPass platform, storing and sharing data through an API. }\end{array}$ \\
$\begin{array}{l}\text { Continued development work to improve the prototype, focusing on tasks } \\
\text { outlined in Table 9. }\end{array}$ \\
\hline October
\end{tabular}




\subsection{Platform specifications}

The features of the PressPass platform, outlined within the tables below, have been based on market research conducted with consumers and news organisations. Table 8 provides an overview of existing functionality with the PressPass prototype. Table 9 outlines current development tasks, as well as expected times for completion. Table 10 provides a summary of additional features that are being considered for future development.

Table 8. Existing functionality of the PressPass platform

\begin{tabular}{|l|l|}
\hline FEATURE & DESCRIPTION \\
\hline Article meter & $\begin{array}{l}\text { The article meter limits the number of free articles that each reader can } \\
\text { view. This feature can be adjusted by publishing partners, allowing them } \\
\text { to determine the exact number of free articles available within their site. } \\
\text { This allows news partners to calculate the ideal threshold for their } \\
\text { website, so that they can maximise conversion rates. This flexibility is } \\
\text { critical for any website with a paywall, as it enables publishers to target } \\
\text { specific readers according to levels of engagement and likelihood of } \\
\text { conversion (Doctor 2013; Doctor 2012) }\end{array}$ \\
\hline Paywall & $\begin{array}{l}\text { Once readers hit their threshold of free articles, our paywall appears and } \\
\text { restricts further reading. Each news partner will have full control over the } \\
\text { news articles they choose to put behind the PressPass paywall. Some } \\
\text { partners will want to put their entire site behind the meter, while others } \\
\text { will prefer to experiment with premium sections of their website. }\end{array}$ \\
\hline Analytics & $\begin{array}{l}\text { Our customised version of the Piwik analytics platform records page } \\
\text { views and time spent reading. }\end{array}$ \\
\hline Social login & $\begin{array}{l}\text { Readers can create an account by signing in with an existing social media } \\
\text { account. We have integrated Facebook, and will have others login } \\
\text { services integrated within the next 4 weeks. }\end{array}$ \\
\hline Payment gateway & $\begin{array}{l}\text { We have integrated PayPal for payment, and will integrate credit card } \\
\text { and online banking once we have selected payment providers. }\end{array}$ \\
\hline
\end{tabular}


Table 9. Current development tasks for the PressPass platform

\begin{tabular}{|l|l|l|}
\hline FEATURE & DESCRIPTION & TIMELINE \\
\hline Reader dashboard & $\begin{array}{l}\text { Allows readers to easily manage their accounts, and } \\
\text { view a list of partner publications }\end{array}$ & By June 2015 \\
\hline $\begin{array}{l}\text { Publisher } \\
\text { dashboard }\end{array}$ & $\begin{array}{l}\text { Allows publishers to gain demographic insights into } \\
\text { reading habits and conversion rates. Also provides a } \\
\text { breakdown of incoming payments from PressPass } \\
\text { royalties and commission (see 10.1). }\end{array}$ & By June 2015 \\
\hline Master dashboard & $\begin{array}{l}\text { Allows PressPass administrators to manage publisher } \\
\text { and reader accounts, and monitor key success metrics. }\end{array}$ & By June 2015 \\
\hline $\begin{array}{l}\text { Customer } \\
\text { database API }\end{array}$ & $\begin{array}{l}\text { Allows users to authenticate with PressPass using their } \\
\text { existing publisher accounts. }\end{array}$ & $\begin{array}{l}\text { Develop once } \\
\text { partnerships } \\
\text { established }\end{array}$ \\
\hline $\begin{array}{l}\text { Cross-platform } \\
\text { API }\end{array}$ & $\begin{array}{l}\text { Allows PressPass login credentials to be used for signing } \\
\text { into the mobile applications of news partners. }\end{array}$ & $\begin{array}{l}\text { Develop once } \\
\text { partnerships } \\
\text { established }\end{array}$ \\
\hline Analytics API & $\begin{array}{l}\text { Allows publishers to easily export all of their PressPass } \\
\text { analytics to other platforms for in-depth analysis. }\end{array}$ & $\begin{array}{l}\text { Develop once } \\
\text { partnerships } \\
\text { established }\end{array}$ \\
\hline
\end{tabular}

Table 10. Future plans for adding extra functionality to the PressPass platform

\begin{tabular}{|l|l|l|}
\hline FEATURE & DESCRIPTION & TIMELINE \\
\hline $\begin{array}{l}\text { Recommended } \\
\text { articles }\end{array}$ & $\begin{array}{l}\text { Provide readers with recommended articles, based on } \\
\text { their reading habits and preferences. }\end{array}$ & $\begin{array}{l}<6 \text { months } \\
\text { after launch }\end{array}$ \\
\hline $\begin{array}{l}\text { Aggregator within } \\
\text { ribbon }\end{array}$ & $\begin{array}{l}\text { Allows readers to easily browse articles by category, } \\
\text { from all news partners. }\end{array}$ & $\begin{array}{l}<12 \text { months } \\
\text { after launch }\end{array}$ \\
\hline $\begin{array}{l}\text { Search bar within } \\
\text { ribbon }\end{array}$ & $\begin{array}{l}\text { Allows readers to search articles across all news } \\
\text { partners. }\end{array}$ & $\begin{array}{l}<6 \text { months } \\
\text { after launch }\end{array}$ \\
\hline $\begin{array}{l}\text { Mobile and } \\
\text { desktop apps }\end{array}$ & $\begin{array}{l}\text { Enable readers to easily browse news from all publishing } \\
\text { partners, within one streamlined app. }\end{array}$ & $\begin{array}{l}<12 \text { months } \\
\text { after launch }\end{array}$ \\
\hline
\end{tabular}

\subsection{Cost projections}

Presspass will have its dynamic data hosted on a dedicated Virtual Private Server (VPS). VPS services are offered by many different cloud service providers, and will be used for running the PIWIK analytics platform, as well as data related to user accounts. As consumer usage of the platform increases, so too will the requirements for our cloud hosting.

Table 11 illustrates the hosting requirements for the PressPass platform at different levels of consumer uptake. The table includes a cost estimate for hosting the dynamic data of PressPass, comparing two cloud-hosting companies that provide Virtual Private 
Servers (VPS). To increase latency and performance, it is best to have a hosting service within New Zealand. With this in mind, the current preference is for VPS City, even though its cost is higher.

Table 11. Cost of Virtual Private Server (VPS) at different scales of usage, for current specifications

\begin{tabular}{|c|c|c|c|c|c|}
\hline Provider & $\begin{array}{l}\text { Hosting } \\
\text { location }\end{array}$ & $\begin{array}{l}\text { Monthly page } \\
\text { impressions }\end{array}$ & $\begin{array}{l}\text { Number of } \\
\text { registered } \\
\text { users }\end{array}$ & $\begin{array}{l}\text { Memory/ number of } \\
\text { processor cores }\end{array}$ & $\begin{array}{l}\text { Cost per } \\
\text { month }\end{array}$ \\
\hline \multirow{3}{*}{$\begin{array}{l}\text { Digital } \\
\text { Ocean }\end{array}$} & \multirow[t]{3}{*}{ USA/ UK } & 100 million & $250 k-500 k$ & $32 \mathrm{~GB} / 12$ & $\$ 320$ USD \\
\hline & & 150 million & 0.5-1 million & $48 \mathrm{~GB} / 16$ & $\$ 480$ USD \\
\hline & & 200 million & 1-1.5 million & $64 G B / 20$ & $\$ 640$ USD \\
\hline \multirow[t]{3}{*}{ VPS City } & \multirow[t]{3}{*}{ NZ } & 100 million & $250 k-500 k$ & 20GB/ 5/ 100GB SSD & \$644 NZD \\
\hline & & 150 million & 0.5-1 million & $32 \mathrm{~GB} / 6 / 250 \mathrm{~GB} S \mathrm{SD}$ & $\$ 1,110$ NZD \\
\hline & & 200 million & 1-1.5 million & $32 \mathrm{~GB} / 6$ / 500GB SSD & $\$ 1,742$ NZD \\
\hline
\end{tabular}

The PressPass platform also contains many static components, such as JavaScript, CSS and Images, which can be hosted for free within a Content Delivery Network (CDN). The development team is currently planning to use the CDN service offered by cloudfare.com, which provides high bandwidth speed and unlimited bandwidth data.

The overall cost of the PressPass system is kept quite low, due to the lightweight nature of the platform. The PressPass ribbon does not require a large amount of data to be transferred for its functionality, and user accounts have minimal data storage requirements. The most data-intensive hosting tasks are instead managed by the servers of news organisations, who host the article content accessed by users. A simplified diagram of data flow is outlined in Figure 16. 


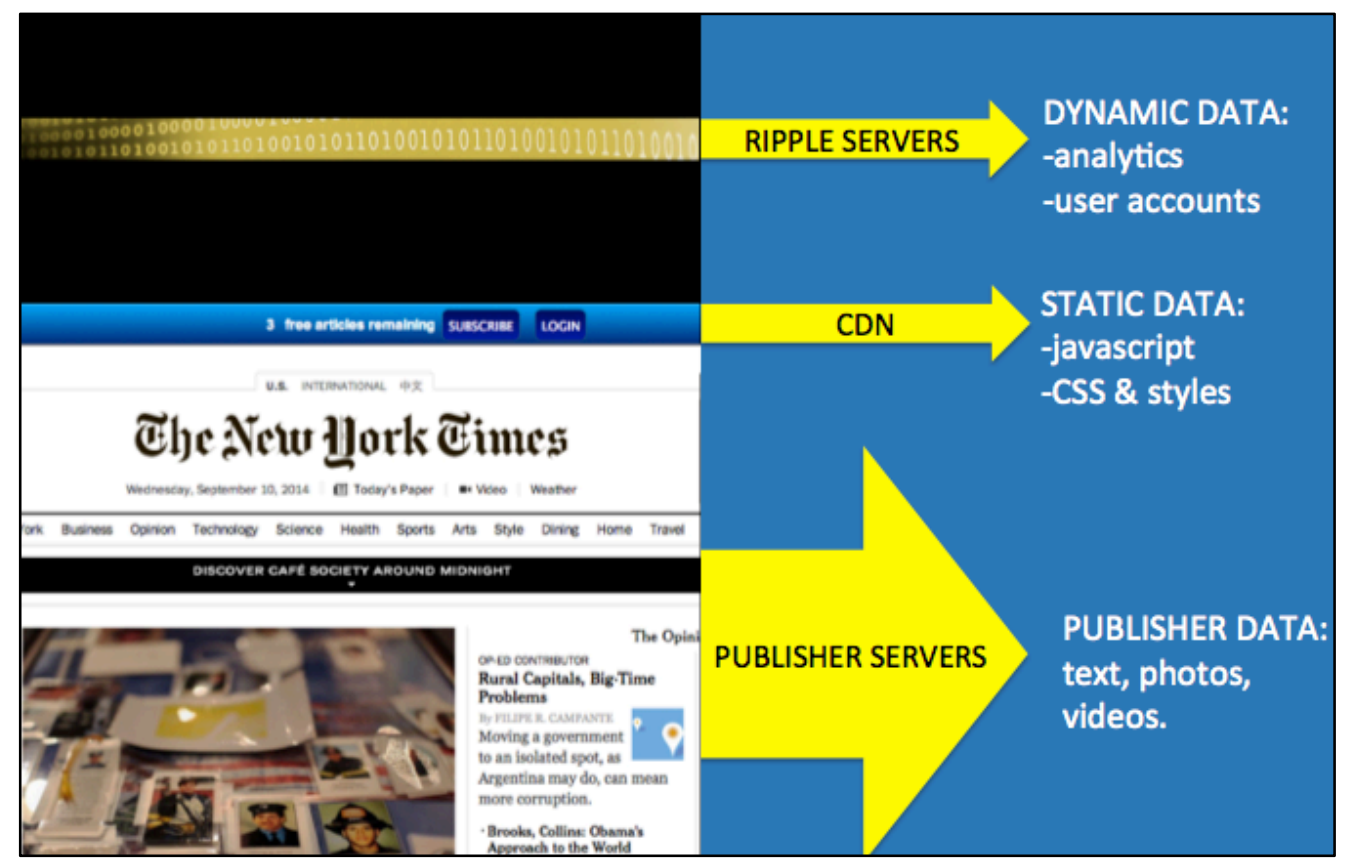

Figure 16. Diagram of data flow required for the PressPass platform 


\section{CHAPTER 7: PUBLICITY}

\subsection{Timeline}

Table 12. Publicity: Timeline of key milestones and activities

\begin{tabular}{|r|l|}
\hline \multicolumn{1}{|c|}{ DATE } & \multicolumn{1}{c|}{ ACTIVITIES } \\
\hline 14 June 2014 & $\begin{array}{l}\text { Alex sends emails to Radio New Zealand's MediaWatch producer, to } \\
\text { discuss the possibility of sharing the PressPass project with listeners. }\end{array}$ \\
\hline 1 July 2014 & $\begin{array}{l}\text { Alex meets with the hosts of MediaWatch (Colin Peacock and Jeremy } \\
\text { Rose). }\end{array}$ \\
\hline 17 July 2014 & Alex is interviewed for the MediaWatch programme. \\
\hline 29 July 2014 & $\begin{array}{l}\text { Alex creates a website to share the PressPass project with the public } \\
\text { (www.fundingnews.co.nz). He provides the URL to MediaWatch, for } \\
\text { promotion within their radio broadcast and online article. }\end{array}$ \\
\hline August 2014 & $\begin{array}{l}\text { The MediaWatch interview is broadcast over the radio, and an article is } \\
\text { posted on the Radio New Zealand website. }\end{array}$ \\
\hline 4 August 2014 & The Victoria University press release is distributed. \\
\hline 4-8 August 2014 & $\begin{array}{l}\text { Alex sends out emails to media outlets, with a one-pager describing the } \\
\text { PressPass project. }\end{array}$ \\
\hline 7 August 2014 & $\begin{array}{l}\text { Alex has a face-to-face interview with the New Zealand Listener's media } \\
\text { columnist. }\end{array}$ \\
\hline 12 August 2014 & $\begin{array}{l}\text { Alex has a phone interview with the National Business Review's media } \\
\text { columnist. }\end{array}$ \\
\hline 13 August 2014 & $\begin{array}{l}\text { Alex has a phone interview with the New Zealand Herald's media } \\
\text { columnist. }\end{array}$ \\
\hline August 2014 2014 & Article is published within the National Business Review. \\
\hline Article is published within the New Zealand Listener. \\
\hline Actober 2014
\end{tabular}

\subsection{Publicity outcomes and strategy}

Media coverage about PressPass can be viewed via the following link: http://www.fundingnews.co.nz/media-coverage

Direct access to each item of media coverage can be viewed via the links below:

Radio New Zealand Interview: https://soundcloud.com/kiwialexnz/news-renewedradio-new-zealand-mediawatch-interview

Victoria University press release: http://www.victoria.ac.nz/sim/about/news/2014news/study-shows-consumers-willing-to-pay-for-online-news 
National Business Review article:

https://www.dropbox.com/s/1k21whhuo91t24i/National\%20Business\%20Review\%20$\% 20 \mathrm{Ad} \% 20$ Hoc.pdf?dl $=0$

New Zealand Herald article:

https://www.dropbox.com/s/rtt4xyz2xb4c4st/NZ\%20Herald.pdf?dl=0

Media publicity was pursued as a strategy to increase early awareness of the PressPass project. The coverage was particularly useful to provide some external validation of the project during the early stages of development, and helped facilitate relationships with individuals within the journalism community.

Several team advisors have recommended taking a hiatus from further publicity until further progress has been made with publisher partnerships. Once the platform has a clear timeline for launch, the next round of media publicity will be focused on raising product awareness among consumers.

To coincide with the New Zealand launch, Alex may also write articles for journals that are popular amongst the international journalism community, such as Walkey's in Australia (www.walkleys.com). This will help raise awareness of the platform, and could facilitate the development of partnerships within international markets. 


\section{CHAPTER 8: LEGAL AND REGULATORY}

\subsection{Timeline}

Table 13. Legal and regulatory: Timeline of key milestones and activities

\begin{tabular}{|l|l|}
\hline DATE & ACTIVITIES \\
\hline May 2014 & $\begin{array}{l}\text { Alex incorporates Ripple Media Limited, the parent company of } \\
\text { PressPass. }\end{array}$ \\
\hline 14 May 2014 & $\begin{array}{l}\text { Alex meets with Ramsey Margolis, head of Huia Co-op, a consulting } \\
\text { company that provides advice regarding the establishment of } \\
\text { cooperative businesses. }\end{array}$ \\
\hline 10 June 2014 & $\begin{array}{l}\text { Alex has a phone call with the Commerce Act Chief Investigator, at the } \\
\text { Commerce Commission. }\end{array}$ \\
\hline 4 July 2014 & Alex Clark and Puneeth Anandaraj sign the PressPass team agreement. \\
\hline 21 July 2014 & $\begin{array}{l}\text { Alex meets with Julie Chrisford from VicLink, to discuss the intellectual } \\
\text { property strategy for the PressPass platform. }\end{array}$ \\
\hline 30 July 2014 & $\begin{array}{l}\text { Alex has a call with Sacha Judd, lawyer at Buddle Finlay, to discuss the } \\
\text { best corporate structure to balance commercial and altruistic goals of } \\
\text { PressPass. }\end{array}$ \\
\hline 7 August 2014 & $\begin{array}{l}\text { Alex meets with Gavin Ellis, author of Trust Ownership and the Future of } \\
\text { News. Discuss possible governance structures to balance commercial } \\
\text { and altruistic goals of PressPass. }\end{array}$ \\
\hline 15 August 2014 & Paul Smith signs the PressPass team agreement. \\
\hline 19 August 2014 & Phone call with Gavin Ellis, continued discussions regarding governance. \\
\hline 19 Nov 2014 & Meeting with Gavin Ellis, continued discussions regarding governance. \\
\hline
\end{tabular}

\subsection{Intellectual property}

The following sections were informed by discussions with Julie Chrisford from VicLink, as well as informal discussions with mentors and advisors within Wellington's start-up community.

\section{Open Source development}

The PressPass team has adopted an open source development strategy, which is a particularly important for creating a relationship of trust and collaboration with the journalism community. Counter-intuitively, an open source strategy requires the establishment of clear ownership and copyright over the source code. This is because 
open source licensing is dependent on the licensor having intellectual property rights over the code.

To ensure clear ownership, each team member has signed a clause within the team agreement that allocates ownership to Ripple Media Limited, under the understanding that the source code will be made available under open source licensing at launch. The team has not yet chosen a specific open source license, and has been advised to apply a license at a later stage once the project has matured. There are many different options available, and the team will need to assess the best possible license that maximises the project's goals. This will be assessed on an ongoing basis, particularly as relationships with news partners and the wider development community are further developed.

\section{Patents}

Early on, it was decided that patents were not a practical solution for PressPass, even when proprietary development was being considered. Not only is it difficult to patent software in New Zealand, but the process also requires a large investment of time and energy. The approval timeframe can extend over a period of 12 months or more, and the level protection is low. Furthermore, competitors within the IT industry can often copy the functionality of a platform without breaking patent laws. Rather than seeking IP protection, the team's main focus with patent law is to conduct a comprehensive 'freedom to operate' search to ensure that no elements of the platform infringe on existing patents. An initial search has not revealed any existing patents that overlap with our functionality, however, a more in-depth search will need to be conducted once the team has the financial resources to do so.

\section{Trademark application}

In November, Alex applied for a trademark to protect the PressPass brand. The process was relatively straightforward, but did involve some external advice to assess the best product/service categories to seek protection within. The application has been accepted, with no objections raised. Once PressPass has further financial resources, trademark applications will be sought in other relevant markets such as Australia and the USA. 


\subsection{Regulatory}

The New Zealand journalism market is one of the most concentrated in the western world, consisting of a near-duopoly between NZME and Fairfax Media. Any initiative that seeks to create collaboration between the two entities is therefore going to be subject to a high level of regulatory scrutiny from the Commerce Commission. With this in mind, Alex reached out to the Commerce Commission early during the development stages to discuss plans, and to ensure that all possible efforts were taken to maintain regulatory compliance. In June, Alex discussed PressPass with the Commerce Act Chief Investigator at the Commerce Commision.

The Chief Investigator was unable to provide specific legal advice due to statutory limitations, and also due to the fact that comprehensive assessments can't be made of hypothetical business models. He did, however, point out the three key sections of the Commerce Act that would apply to the project. Section 27, Agreements that substantially lessen competition, applies if a business undertakes actions that lower the level of competition in the market. Section 36, Taking advantage of market power, applies if a business has a substantial degree of market power and takes advantage of that power. Section 30, Certain provisions of contracts with respect to prices deemed to substantially lessen competition, is focused on addressing issues that arise when companies attempt to fix, maintain or control pricing through unfair practices.

His preliminary view was that Section 27 did not apply, pointing out that the proposed platform was unlikely to lessen competition as there are dozens of providers of online news and information, as well as several platforms through which news is shared. Furthermore, Section 36 is unlikely to apply due to the low market power of PressPass. Section 30 is unlikely to be an issue, since each competitor is negotiating with PressPass independently, resulting in a normal supplier and purchaser agreement.

Specific actions that he said would trigger a high level of regulatory scrutiny, included direct negotiation between publishers about prices within the platform. Furthermore, direct ownership or investment from publishers would trigger a very high level of scrutiny from the Commerce Commission. 
He did point out that Section 31 provides limited exceptions within the Commerce Act, that allow for companies to pursue joint ventures in exceptional circumstances for the purposes of additional services. Even under these circumstances, PressPass would face a very high level of scrutiny, and may not meet the criteria for a joint venture if there was direct investment from publishers.

Since independence is already a prominent principle guiding the PressPass platform, it is expected that our current strategy of avoiding direct media ownership will be beneficial both legally, commercially and altruistically.

\subsection{Corporate structure}

During the early stages of PressPass, the team had discussed the possibility of cooperative ownership to increase adoption by the journalism community and maximise equitability. Alex had discussions with several individuals who had understanding of cooperative structures, and asked for their advice. A common theme that emerged was that cooperatives are extremely delicate organisations to maintain, and are most successful when there is very strong alignment between members. In the case of PressPass, the highly competitive nature of the journalism industry creates the risk of inherent instability if structured as a cooperative business.

Many contacts within the journalism industry emphasised the recent failure of NZPA, a cooperative newswire agency that ultimately collapsed. From a collective perspective, it made logical sense for the service to be maintained, and the dissolution had a detrimental impact on the wider New Zealand journalism industry. However, competitive rivalries had lead some members to believe that it was in their own selfinterest to abandon the initiative, and thought it would have a greater negative impact on their competitors than themselves. Industry contacts expressed a belief that PressPass would be more stable as an independent entity, with a strong mandate to operate in the collective interest of the journalism community, rather than operating as a collective of members focused on maximising their own self-interest.

Other limitations of a cooperative structure were the added complexity of regulatory requirements related to incorporation and membership obligations. It was recommended 
that the pursuit of collective goals could be achieved through a more simple corporate structure, with a carefully crafted constitution and articles of association. Furthermore, the underlying business model of PressPass can be used to enshrine altruistic goals within the day-to-day operations of the platform, as demonstrated with our proposed commission structure.

As the platform is further developed, the corporate structure will continue to be refined. It has been advised that the team should avoid committing itself to a particular corporate structure while the PressPass team is small and without investors, to provide maximum flexibility to the changing needs of the business. With this advice in mind, PressPass was incorporated under the parent company of Ripple Media Limited in May 2014, as a limited liability company with the default corporate structure. The structure will be assessed on an ongoing business at pivotal stages, such as discussions about potential investment or the development of news partnerships.

\subsection{Team agreement and ownership structure}

The team agreement for PressPass has been a pivotal document that outlines team member's expectations and obligations regarding ongoing development of the platform. Key provisions include the transfer of intellectual property to the parent company, Ripple Media Limited, as well as outlines regarding the future allocation of equity and remuneration.

The team's mentor, Michael Elwood-Smith has been particularly influential during the formation of this agreement, emphasising the need for fluid provisions that meet the flexible requirements of start-up businesses. In particular, he highlighted the importance of outlining clear principles so that the project could move forward with mutual alignment of expectations.

In regards to equity, he recommended avoiding an exact distribution until a significant event of market validation, such as imminent investment or partnership contracts. At this stage, it will become easier to assess the value of the enterprise, as well as the past contributions and intended future contributions of each team member. 
Factors that will be considered to allocate ownership include the proportion of hours contributed, the amount of personal finances invested in the company, and overall contribution to the success of the enterprise. An outside mediator will be consulted if any team members wish to get a second opinion during the process of equity allocation, and the team agreement will be renewed on a regular basis to ensure all team members continue to agree with its provisions. 


\section{CHAPTER 9: FUNDING AND INVESTMENT}

\section{$9.1 \quad$ Timeline}

Table 14. Funding and investment: Timeline of key milestones and activities

\begin{tabular}{|c|c|}
\hline DATE & ACTIVITIES \\
\hline 13 March 2014 & $\begin{array}{l}\text { Alex has a meeting with Dave Allison, Manager of the Angel HQ } \\
\text { investment network. }\end{array}$ \\
\hline 17 June 2014 & Alex has meeting with an investor met through the Angel HQ network. \\
\hline 6 August 2014 & $\begin{array}{l}\text { Alex has a Skype call with Dan Sinker, head of the Knight Mozilla } \\
\text { OpenNews project, which funds online journalism projects. }\end{array}$ \\
\hline 20 August 2014 & $\begin{array}{l}\text { Alex has a Skype call with Marie Gilot, programme officer at the } \\
\text { Knight Foundation, which funds online journalism projects. }\end{array}$ \\
\hline 22 August 2014 & $\begin{array}{l}\text { Alex has a meeting with Jordan Carter, CEO of Internet New Zealand. } \\
\text { Discussion about funding that could be available through INZ grants. }\end{array}$ \\
\hline 8 September 2014 & $\begin{array}{l}\text { Alex visits Harvard's Nieman Journalism Lab. Meets with Nieman Lab } \\
\text { journalists, as well as the director of their fellowship programme. }\end{array}$ \\
\hline 23 September 2014 & $\begin{array}{l}\text { Alex meets with Dawn Garcia, Managing Director of John S. Knight } \\
\text { Journalism Fellowships at Stanford. }\end{array}$ \\
\hline 29 September 2014 & $\begin{array}{l}\text { Alex has meeting with New Zealand Trade and Enterprise's Business } \\
\text { Development Manager for the San Francisco Bay Area. }\end{array}$ \\
\hline 11 Nov 2014 & Alex has meeting with Alan Hucks, head of incubation at Creative HQ. \\
\hline 13 Nov 2014 & $\begin{array}{l}\text { Alex has meeting with the coordinators of Lightning Lab 2015: Connor } \\
\text { Archbold (programme manager) and Mark MacLeod-Smith } \\
\text { (programme director). }\end{array}$ \\
\hline 17 Nov 2014 & $\begin{array}{l}\text { Alex has phone call with John Holt, director of the Kiwi Landing Pad in } \\
\text { San Francisco. }\end{array}$ \\
\hline 1 December 2014 & $\begin{array}{l}\text { Submission of applications for Stanford's JSK journalism innovation } \\
\text { fellowship, and Harvard's Nieman-Berkman fellowship in journalism } \\
\text { innovation. }\end{array}$ \\
\hline 8 December 2014 & $\begin{array}{l}\text { Alex is invited to attend a Lightning Lab Bootcamp in Auckland, and } \\
\text { continues discussions with coordinators. }\end{array}$ \\
\hline 11 December 2014 & $\begin{array}{l}\text { Alex has a meeting with Geoff Todd, managing director of VicLink, to } \\
\text { discuss potential support as well as investment strategies. }\end{array}$ \\
\hline 12 December 2014 & $\begin{array}{l}\text { Alex has a meeting with R\&D investment managers at Grow } \\
\text { Wellington, to discuss Callaghan Innovation funding. }\end{array}$ \\
\hline 16 December 2014 & $\begin{array}{l}\text { Alex meets with Sean Wilson, CEO of Syl Semantics. Discuss } \\
\text { preparation of an investment proposal. }\end{array}$ \\
\hline 17 December 2014 & Alex, Puneeth and Paul complete their Lightning Lab application. \\
\hline 7 January 2014 & $\begin{array}{l}\text { Alex has meeting with Dave Allison, manager of Angel HQ. Discuss } \\
\text { preparation of an investment proposal }\end{array}$ \\
\hline 7 January 2014 & $\begin{array}{l}\text { Alex has meeting with a Business Growth Manager at Grow } \\
\text { Wellington, after being referred by R\&D investment managers. }\end{array}$ \\
\hline 15 January 2014 & $\begin{array}{l}\text { Alex, Puneeth and Paul have interview with the Lightning Lab } \\
\text { selection panel, after being shortlisted among the top } 20 \text { teams. }\end{array}$ \\
\hline 20 January 2014 & $\begin{array}{l}\text { Alex has a meeting with an Angel HQ investor to discuss development } \\
\text { of an investment proposal. }\end{array}$ \\
\hline
\end{tabular}




\subsection{Private investment}

Dave Allison, the manager of Angel HQ, has provided an advisory role to PressPass, for many aspects of private investment. Other important advisors have been Sean Wilson, the CEO of Syl Semantics, as well as a range of individuals within Wellington's startup community. Key feedback throughout the year has emphasised the importance of establishing firm contractual partnerships with news organisations. While investment may be possible based on current publisher relationships, a greater the level of commitment will increase the value of PressPass, allowing larger amounts of capital to be raised in return for less equity.

A delicate cost-benefit assessment is required before raising money, finding the ideal balance between pursuing money to fund growth, and pursuing growth to maximise the amount that can be raised. In terms of investors, it has been advised to seek individuals with domain expertise within the journalism industry, so that an investor can be found with a strong understanding of the problem space and can fully grasp the potential of PressPass' solution. Some advisors recommended direct investment from publishers, to maximise their commitment to the platform's success. This, however, would hinder the platform's independence and result in additional requirements to meet Commerce Commission legislation.

One private investment pathway pursued by the PressPass team, was the Lightning Lab accelerator programme. The programme coordinators were quite enthusiastic about the potential of PressPass. The PressPass team was eventually shortlisted within the top twenty applicants, and travelled to Auckland for an interview. Although impressed with the team's progress, the selection panel was ultimately concerned that it might be too early for PressPass to undergo acceleration. In particular, they were apprehensive to accelerate before contractual partnerships had been finalised with news organisations.

The interview panel also expressed concerns at the number of delays that both NZME and Fairfax have had with their paid-content strategy, and pointed out that this implies a lack of coherent strategy. While this does provide an opportunity for a company such as PressPass to help shape the decision-making process and become part of the solution, 
they were concerned that it left the company vulnerable to factors outside of the team's control.

One potential strategy to increase commitment from publishers includes special introductory commission rates for those who first sign agreements, creating a first mover advantage that incentivises commitment. Another possible strategy recommended by advisors, has been the use of partnership agreements that are activated when a certain threshold of partners have joined the platform. This would de-risk the perceived risk of launching a paywall. However, such a policy would need to be pursued only after consultation with the Commerce Commission to ensure alignment with relevant legislation.

\subsection{Philanthropy and academic grants}

Throughout the year, Alex has explored potential funding opportunities available from universities and other philanthropic bodies. Most of these opportunities have been available within the USA. Several individuals recommended applying for Harvard's Nieman-Berkman fellowship in journalism innovation, as well as Stanford's JSK journalism fellowship. Each fellowship offered an opportunity to develop a journalism innovation project focused on both academic research and product development, providing funding and institutional support. Alex applied for both opportunities, however, was ultimately unsuccessful. Alex had met with the directors of each fellowship programme while visiting the USA, and they were impressed with the project and encouraged him to apply. They had warned, however, that competition would be high (400-500+ applicants) and that priority would be given to mid-career journalists currently employed within news organisations.

Another potential source of funding explored was the Knight Foundation, which funds journalism innovation projects. Alex reached out to head of the Knight OpenNews initiative, Dan Sinker, who coordinates funds for open source news projects and fellowships. The conversation revealed that the core of their funding is predominantly focused on development projects embedded within newsrooms, without specific funding available for independent initiatives. Dan did, however, show an interest in the 
project, and recommended a discussion with Marie Gilot within the Knight Foundation. He also said that having an open source focus would be a strong advantage when applying for grant funding.

Alex asked Marie for further details about the Knight Prototype grant, a \$50,000 contribution towards the development of a functional prototype. While she said that PressPass would be an ideal candidate, the funding is limited to projects based within the USA. Alex explored whether it would be possible to channel funding through a US partner, however this had not been done in the past and was considered to be an unlikely scenario. Funding that is available to international projects includes the Knight News Challenge, which funds news-focused start-up companies. However, funding is usually focused on non-profits, and each year the initiative is themed to focus on a particular category of news project. Another option available to international projects is the Knight Foundation's venture capital investment programme, which the PressPass team may consider once they are ready to seek investment.

In New Zealand, Alex has met with the CEO of Internet New Zealand to discuss potential grant funding that PressPass could apply for. A particularly promising initiative is an upcoming Internet Project Funding Round, being launch in June 2015. There is the potential that PressPass could be eligible, however, the project will need to align closely with the goals of the funding and have a clear community benefit. The team will be meeting with the coordinator of this initiative to discuss whether the project has a strong chance of success and alignment with INZ goals, before committing resources to an application.

Alex also had meetings with VicLink to discuss potential support from Victoria University. Although VicLink have previously invested in start-up companies emerging from Victoria, they no longer have budget allocation available for such investment activities. Grant Todd mentioned that he is working to establish funding for sustaining university enterprise projects following course completion, and thought that PressPass would be an ideal candidate for such funding. Unfortunately, however, this initiative is not likely to be ready in the near future. Geoff emphasised that VicLink's current core mandate is to fund intellectual property owned by the university, and since PressPass is an independent company with full ownership over IP, they do not have a mandate to 
invest and assist with growth. He did, however, offer the option of limited funding to provide office space and mentorship to assist with the ongoing development process, and this offer will be taken up by the PressPass team.

The PressPass team will continue to explore philanthropic funding opportunities. However, the team will need to be careful about the complex requirements and specific outcomes that are often tied to funding. PressPass is a young company that needs the flexibility to grow and explore opportunities, and the team will need to seek funding that aligns with its goals.

\subsection{Government funding}

Alex has also explored the potential of government funding, looking into the options available through New Zealand Trade and Enterprise, as well as Callaghan Innovation funding allocated by Grow Wellington. At NZTE, Alex met with the business development manager for the San Francisco Bay Area. Alex enquired about a variety of NZTE funding initiatives, and the stage at which they would be most appropriate for PressPass. Alex was advised that the KLP8 programme would be the ideal starting point. This programme provides funding for flights and other expenses to spend 6-8 weeks testing market viability within the USA, while being based at the Kiwi Landing Pad. Further down the track, the Beachheads programme could also be useful to assist with more long-term establishment within the US market, supporting larger businesses with their expansion activities.

At Grow Wellington, Alex met with R\&D investment managers, as well as a business growth manager. The $R \& D$ managers explained that $R \& D$ project grants could be available to fund the development of new technology, particularly aspects of the PressPass platform that involve novel technical challenges. 'Getting Started' funding was recommended as a good first step, as it provides early support to fund project mapping that scopes out each core component of a project and helps outline core R\&D tasks that could be eligible for further funding. All grants from Grow Wellington involve matching funding, therefore PressPass will need to establish investment before 
funding can be approved. Once investment has been secured, further steps will be taken to apply for funding via Grow Wellington. 


\section{CHAPTER 10: FINANCIAL ANALYSIS}

\subsection{Pricing, commission structure and royalty distribution}

This section provides the proposed strategy for PressPass' pricing, commission, and royalty distribution, based on feedback obtained during meetings with potential news partners. Note that the following subsections contain variables that could change following further negotiations with news organisations.

\section{Pricing}

Each news organisation will be allowed to determine the pricing for a standalone subscription to their website. Pricing for the National PressPass and Global PressPass will be based on comprehensive market research to assess the ideal price point for each package. To determine a launch price, possible market research techniques include the Gabor-Granger method, as well as Van Westendorp's Price Sensitivity Meter. After launch, actual uptake rates will be compared to projections on an ongoing basis, with pricing adjusted as necessary to promote further uptake and maximise overall subscription revenue.

\section{PressPass commission}

We propose to take zero commission for sales of a standalone subscription to a single news website within the PressPass ecosystem. This will allow PressPass to be the cheapest available solution for standalone paywall infrastructure, minimising the costs of adoption and creating an incentive for publishers to switch to our platform if using a competitor's product. For sales of the national and global packages, we propose to take $20 \%$ commission. Furthermore, we plan to further reduce our commission as profit margins increase. Our low commission structure will be an important competitive advantage, allowing us to operate in a trustworthy manner that is transparent, fair and equitable to our news partners. 


\section{Conversion commission}

If a publisher converts a subscriber to the national or global package, they will be rewarded with a conversion commission. We propose that this commission will be $20 \%$ of the sale price for the first 24 months of payments. The conversion commission will serve as a further incentive for news partners to convert readers to the national or global package.

\section{Royalty distribution}

After the PressPass commission and conversion commission have been collected, all subscription revenue will be placed within a royalty pool to be distributed between our news partners. Our royalty distribution method will be aimed at equitably rewarding news organisations, relative to the level of reader engagement with their news content. Half of the royalty pool will be proportionally distributed based on page views, while the other half will be proportionally distributed according to time spent reading. Royalty payments for the national and global packages will be allocated from separate pools.

\section{Revenue flow: hypothetical breakdown}

The following scenario describes how revenue would be distributed, under the policies outlined above. This scenario describes the distribution of the first one million dollars in subscription fees collected from subscribers to the global package. A hypothetical news partner, Publisher XYZ, is used for illustrative purposes.

Step 1) PressPass receives a $20 \%$ commission for providing the platform infrastructure, receiving $\$ 200,000$ in commission fees.

Step 2) An additional 20\% from each sale is distributed as a conversion commission, paid directly to news partners whenever they convert a paying subscriber within their website. This amounts to a total of $\$ 200,000$ for all news partners. Publisher XYZ converted $40 \%$ of all subscribers during this period, receiving a total of $\$ 80,000$ commission.

Step 3) The remaining $60 \%$ of each sale is placed within a royalty pool, totalling $\$ 600,000$. This royalty pool is distributed between news partners every calendar month. 
i) Half of this royalty pool is distributed between publishers based on the proportion of page views they receive, totalling $\$ 300,000$. Publisher XYZ generated $45 \%$ of all page views from subscribers to the global package, receiving $\$ 135,000$.

ii) The other half of this royalty pool is distributed according to the proportion of time spent on each website, totalling $\$ 300,000$. Publisher XYZ accounted for $40 \%$ of the reading time accumulated by subscribers to the global package, receiving $\$ 120,000$.

Step 4) The same commission structure and royalty distribution method outlined above, is used to allocate revenue from the national package. The royalty pools, however, are kept separate and are allocated according to the readership metrics specific to each pool of subscribers.

\subsection{Financial model comparing a standalone strategy with global bundling}

High-level summary:

- News organisations can expect to make significantly more revenue if they adopt a strategy of global bundling.

- Under a standalone subscription strategy, the New Zealand Herald would generate an estimated $\$ 3.8$ million in annual revenue.

- By participating in a global bundle, the New Zealand Herald would generate an estimated \$7.6 million in annual revenue. This is a two-fold increase, and higher than the revenue generated by the entire industry under a standalone strategy.

- Under a standalone subscription strategy, the total estimated revenue generated by all news organisations is $\$ 7.4$ million.

- Under a global subscription strategy, the total estimated revenue generated by all news organisations is $\$ 28$ million, a 3.8 times increase.

The estimates within this section are based on actual readership metrics, provided within a custom report generated from October 2014's Nielsen Online Ratings (personal 
communication, H. Ottow, 19 November, 2014). For the purpose of simplicity, this section focuses on the estimated revenue of the New Zealand Herald website under a standalone strategy, compared with their estimated revenue from participating in a global bundle of news websites.

The global bundle is based on a hypothetical launch package, containing nzherald.co.nz, stuff.co.nz, 3news.co.nz, tvnz.co.nz/news, nytimes.com, nationalgeographic.com and economist.com. The total unduplicated audience of these websites is 2.1 million monthly unique visitors (Nielsen Online Ratings).

For the purposes of this financial model, it is assumed that two thirds of respondents who said 'definitely' would actually purchase a news subscription, along with one third of respondents who said 'probably'. For a standalone subscription, this results in an estimated conversion rate of $2.4 \%$, and a rate of $10.3 \%$ for a global news package.

A rough estimate of the ideal price point has been calculated using the mean preferred price of respondents ${ }^{5}$. For a standalone subscription, the mean preferred price point was $\$ 8.60$. For a global package, the mean preferred price point was $\$ 10.80$.

Under a standalone subscription strategy, all news organisations would earn an estimated \$7.4 million within the New Zealand market (Table 15). This is based on a cumulative news audience of 3.75 million, including duplicate users who visit multiple sites.

Table 15. Estimated revenue under standalone package, all news organisations

\begin{tabular}{|r|r|r|r|r|c|}
\hline $\begin{array}{c}\text { Culmulative online } \\
\text { news audience in NZ } \\
\text { (all news partners) }\end{array}$ & $\begin{array}{c}\text { Estimated } \\
\text { conversion rate }\end{array}$ & $\begin{array}{c}\text { Number of } \\
\text { subscribers }\end{array}$ & $\begin{array}{c}\text { Monthly } \\
\text { subscription fee }\end{array}$ & $\begin{array}{c}\text { Total annual } \\
\text { revenue }\end{array}$ & $\begin{array}{c}\text { Annual revenue after } \\
\text { PressPass commission } \\
\text { (20\%) }\end{array}$ \\
\hline $3,745,000$ & $2.40 \%$ & 89,880 & $\$ 8.60$ & $\$ 9,275,616$ & $\$ 7,420,493$ \\
\hline
\end{tabular}

Under a standalone subscription strategy, the New Zealand Herald's estimated revenue is $\$ 3.28$ million (Table 16).

\footnotetext{
${ }^{5}$ The mean preferred price was calculated from respondents who said that they would 'definitely' or 'probably' pay for each option.
} 
Table 16. Estimated revenue under a standalone package, New Zealand Herald

\begin{tabular}{|c|r|r|r|c|}
\hline $\begin{array}{c}\text { Unique audience } \\
\text { (NZ Herald) }\end{array}$ & $\begin{array}{c}\text { Estimated } \\
\text { conversion rate }\end{array}$ & $\begin{array}{c}\text { Number of } \\
\text { subscribers }\end{array}$ & $\begin{array}{c}\text { Monthly } \\
\text { subscription fee }\end{array}$ & $\begin{array}{c}\text { Total annual } \\
\text { revenue }\end{array}$ \\
\hline $1,325,000$ & $2.40 \%$ & 31,800 & $\$ 8.60$ & $\$ 3,281,760$ \\
\hline
\end{tabular}

Under a global bundling strategy, the total estimated revenue generated within the entire ecosystem is \$28 million. After PressPass takes a 20\% commission on each sale, the total annual revenue distributed to news partners is $\$ 22.4$ million (Table 17).

Table 17. Total revenue under a global bundling strategy, all publishing partners

\begin{tabular}{|r|r|r|r|r|c|}
\hline $\begin{array}{c}\text { Unduplicated online } \\
\text { news audience in NZ } \\
\text { (all news partners) }\end{array}$ & $\begin{array}{c}\text { Estimated } \\
\text { conversion rate }\end{array}$ & $\begin{array}{c}\text { Number of } \\
\text { subscribers }\end{array}$ & $\begin{array}{c}\text { Monthly } \\
\text { subscription fee }\end{array}$ & $\begin{array}{c}\text { Total annual } \\
\text { revenue }\end{array}$ & $\begin{array}{c}\text { Annual revenue after } \\
\text { PressPass commission } \\
\text { (20\%) }\end{array}$ \\
\hline $2,100,000$ & $10.30 \%$ & 216,300 & $\$ 10.80$ & $\$ 28,032,480$ & $\$ 22,425,984$ \\
\hline
\end{tabular}

Within this ecosystem, the New Zealand Herald can expect to receive a total of $\$ 7.64$ million in payments (Table 18). This is 2.3 times greater than the revenue generated under a standalone strategy, and results in an additional $\$ 4.4$ million in annual revenue.

Table 18. Estimated revenue under a global bundling strategy, New Zealand Herald

\begin{tabular}{|l|c|c|c|l|}
\cline { 2 - 5 } \multicolumn{1}{c|}{$\begin{array}{l}\text { Conversion } \\
\text { commission }\end{array}$} & $\begin{array}{l}\text { Royalty payment: } \\
\text { page views }\end{array}$ & $\begin{array}{l}\text { Royalty payment: } \\
\text { time spent reading }\end{array}$ & $\begin{array}{l}\text { TOTAL } \\
\text { PAYMENTS }\end{array}$ \\
\hline NZ Herald & $\$ 1,836,673$ & $\$ 2,961,943$ & $\$ 2,840,600$ & $\$ 7,639,216$ \\
\hline
\end{tabular}

\subsection{PressPass revenue model}

High-level summary:

- Within the New Zealand market

○ A high annual revenue estimate is $\$ 12.9$ million

○ A medium annual revenue estimate is $\$ 6.5$ million

- A low annual revenue estimate is $\$ 3.2$ million

- Within the Australian market

- A low annual revenue estimate is $\$ 16.6$ million 
- Within the US market

- A low annual revenue estimate is $\$ 255$ million

This section provides a simplified revenue model for the PressPass platform, based on different levels of success. It does not account for the cumulative acquisition of consumers over time, and instead provides a 12-month extrapolation of the revenue generated during one month of operation at the level of metrics stated.

Assumptions include

-A total New Zealand news audience of 2.1 million monthly unique users.

-A subscription fee of $\$ 11$ per month for the Global PressPass package. ${ }^{6}$

-A subscription fee of $\$ 9$ per month for the National PressPass package. ${ }^{7}$

-A ratio of 1:5 between the conversion rate of the national package and global package. ${ }^{8}$

-Participation by all major news organisations that are most popular within each launch market

-Note: revenue is not calculated for standalone subscriptions, since PressPass takes zero commission for this subscription option.

A high estimate of the subscriber conversion rate (20\% global package, $4 \%$ national package) results in a total annual PressPass commission of $\$ 12.9$ million within the New Zealand market (Table 19).

Table 19. Revenue model for New Zealand, high conversion rate estimate

\begin{tabular}{|c|c|c|c|c|c|c|}
\hline & $\begin{array}{c}\text { Unduplicated online } \\
\text { news audience in NZ } \\
\text { (all news partners) }\end{array}$ & Conversion rate & $\begin{array}{l}\text { Number of } \\
\text { subscribers }\end{array}$ & $\begin{array}{c}\text { Monthly } \\
\text { subscription fee }\end{array}$ & $\begin{array}{l}\text { Total annual } \\
\text { revenue }\end{array}$ & $\begin{array}{l}\text { PressPass commission } \\
(20 \%)\end{array}$ \\
\hline Global PressPass & \begin{tabular}{r|}
$2,100,000$ \\
\end{tabular} & $20.00 \%$ & 420,000 & $\$ 11.00$ & $\$ 55,440,000$ & $\$ 11,088,000$ \\
\hline National PressPass & $2,100,000$ & $4.00 \%$ & 84,000 & $\$ 9.00$ & $\$ 9,072,000$ & $\$ 1,814,400$ \\
\hline & & & & \multicolumn{2}{|c|}{ TOTAL ANNUAL COMMISSION } & $\$ 12,902,400$ \\
\hline
\end{tabular}

\footnotetext{
${ }^{6}$ Mean preferred price point, rounded to the nearest dollar

${ }^{7}$ Mean preferred price point, rounded to the nearest dollar

${ }^{8}$ Based on the ratio of subscribers willing to definitely pay for each of these packages.
} 
A medium estimate of the subscriber conversion rate (10\% global package, $2 \%$ national package) results in a total annual PressPass commission of $\$ 6.5$ million within the New Zealand market (Table 20).

Table 20. Revenue model for New Zealand, medium conversion rate estimate

\begin{tabular}{|c|c|c|c|c|c|c|}
\hline & $\begin{array}{c}\text { Unduplicated online } \\
\text { news audience in NZ } \\
\text { (all news partners) }\end{array}$ & Conversion rate & $\begin{array}{l}\text { Number of } \\
\text { subscribers }\end{array}$ & $\begin{array}{c}\text { Monthly } \\
\text { subscription fee }\end{array}$ & $\begin{array}{c}\text { Total annual } \\
\text { revenue }\end{array}$ & $\begin{array}{c}\text { PressPass commission } \\
(20 \%)\end{array}$ \\
\hline Global PressPass & $2,100,000$ & $10.00 \%$ & 210,000 & $\$ 11.00$ & $\$ 27,720,000$ & $\$ 5,544,000$ \\
\hline National PressPass & $2,100,000$ & $2.00 \%$ & 42,000 & $\$ 9.00$ & $\$ 4,536,000$ & $\$ 907,200$ \\
\hline & & & & \multicolumn{2}{|c|}{ TOTAL ANNUAL COMMISSION } & $\$ 6,451,200$ \\
\hline
\end{tabular}

A low estimate of the subscriber conversion rate (5\% global package, $1 \%$ national package) results in a total annual PressPass commission of $\$ 3.2$ million within the New Zealand market (Table 21).

Table 21. Revenue model for New Zealand, low conversion rate estimate

\begin{tabular}{|l|r|r|r|r|r|r|}
\cline { 2 - 7 } \multicolumn{1}{c|}{} & $\begin{array}{c}\text { Unduplicated online } \\
\text { news audience in NZ } \\
\text { (all news partners) }\end{array}$ & Conversion rate & $\begin{array}{c}\text { Number of } \\
\text { subscribers }\end{array}$ & $\begin{array}{r}\text { Monthly } \\
\text { subscription fee }\end{array}$ & $\begin{array}{r}\text { Total annual } \\
\text { revenue }\end{array}$ & $\begin{array}{c}\text { PressPass commission } \\
\text { (20\%) }\end{array}$ \\
\hline Global PressPass & $2,100,000$ & $5.00 \%$ & 105,000 & $\$ 11.00$ & $\$ 13,860,000$ & $\$ 2,772,000$ \\
\hline National PressPass & $2,100,000$ & $1.00 \%$ & 21,000 & $\$ 900$ & $\$ 2,268,000$ & $\$ 453,600$ \\
\cline { 2 - 7 }
\end{tabular}

If PressPass successfully expands into the Australian market, there is a total online news audience of 10.8 million unique adult visitors (The Newspaper Works, 2015). A low estimate of the conversion rate (5\% global package, $1 \%$ national package), results in a total annual commission of $\$ 16.6$ million (Table 22).

Table 22. Revenue model for Australian expansion, low conversion rate estimate

\begin{tabular}{|l|r|r|r|r|r|r|}
\cline { 2 - 7 } & $\begin{array}{c}\text { Unduplicated online } \\
\text { news audience in } \\
\text { Australia }\end{array}$ & Conversion rate & $\begin{array}{c}\text { Number of } \\
\text { subscribers }\end{array}$ & $\begin{array}{c}\text { Monthly } \\
\text { subscription fee }\end{array}$ & $\begin{array}{c}\text { Total annual } \\
\text { revenue }\end{array}$ & $\begin{array}{c}\text { PressPass commission } \\
\mathbf{( 2 0 \% )}\end{array}$ \\
\hline Global PressPass & $10,800,000$ & $5.00 \%$ & 540,000 & $\$ 11.00$ & $\$ 71,280,000$ & $\$ 14,256,000$ \\
\hline National PressPass & $10,800,000$ & $1.00 \%$ & 108,000 & $\$ 9.00$ & $\$ 11,664,000$ & $\$ 2,332,800$ \\
\hline
\end{tabular}

If PressPass successfully expands into the US market, there is a total online news audience of 166 million unique adult visitors (Conaghan, 2014). A low estimate of the 
conversion rate (5\% global package, $1 \%$ national package), results in a total annual commission of $\$ 255$ million (Table 23).

Table 23. Revenue model for USA expansion, low conversion rate estimate

\begin{tabular}{|l|r|r|r|r|r|r|}
\cline { 2 - 6 } & \multicolumn{1}{c|}{$\begin{array}{c}\text { Unduplicated online } \\
\text { news audience in the } \\
\text { USA }\end{array}$} & Conversion rate & $\begin{array}{c}\text { Number of } \\
\text { subscribers }\end{array}$ & $\begin{array}{r}\text { Monthly } \\
\text { subscription fee }\end{array}$ & $\begin{array}{c}\text { Total annual } \\
\text { revenue }\end{array}$ & $\begin{array}{c}\text { PressPass commission } \\
\mathbf{( 2 0 \% )}\end{array}$ \\
\hline Global PressPass & $166,000,000$ & $5.00 \%$ & $8,300,000$ & $\$ 11.00$ & $\$ 1,095,600,000$ & $\$ 219,120,000$ \\
\hline National PressPass & $166,000,000$ & $1.00 \%$ & $1,660,000$ & $\$ 9.00$ & $\$ 179,280,000$ & $\$ 35,856,000$ \\
\cline { 2 - 7 }
\end{tabular}




\section{Bibliography}

APN News and Media. (2014). Supplemental Disclosure Information. Retrieved from http://investorcentre.apn.com.au/phoenix.zhtml?c=144006\&p=irol-news\&nyo=1

Conaghan, J. (2014). Newspaper Web Audience. Retrieved February 25, 2015, from http://www.naa.org/Trends-and-Numbers/Newspaper-Websites/NewspaperWeb-Audience.aspx

Doctor, K. (2012). The newsonomics of Pricing 201. from http://www.niemanlab.org/2012/09/the-newsonomics-of-pricing-201/

Ellis, J. (2014). If my newspaper puts up a metered paywall, how many people will pay? Here's some data. from http://www.niemanlab.org/2014/05/if-mynewspaper-puts-up-a-metered-paywall-how-many-people-will-pay-heres-somedata/

Fahy, B. (2014). Audience up, ad spend down: A depressing graph for Fairfax and APN? Or dodgy data? , from http://stoppress.co.nz/blog/2014/02/apn-fairfaxonline-ad-spend

Gray, J. (2015, February 13). Pay wall plan on track, says APN chief, New Zealand Herald. Retrieved from http://www.nzherald.co.nz/business/news/article.cfm?c_id=3\&objectid=114010 63

Grueskin, B., Seave, A., \& Graves, L. (2011). The story so far: What we know about the business of digital journalism. NY: Columbia Journalism School, Tow Center for Digital Journalism. Retrieved from http://cjrarchive.org/img/posts/report/The Story So Far.pdf

Myllylahti, M. (2013). JMAD New Zealand Media Ownership Report 2013. Retrieved from

http://www.academia.edu/5252012/JMAD New_Zealand Media_Ownership R eport 2013

Pullar-Strecker, T. (2014). No paywall plans for news. Retrieved February 24, 2015, from http://www.stuff.co.nz/business/industries/63200873/fairfax-nz-has-nopaywall-plans-for-news

Siapera, E., \& Veglis, A. (Eds.). (2012). The Handbook of Global Online Journalism. West Sussex, UK: Wiley-Blackwell.

The New York Times. (2014). Innovation. NY: The New York Times. Retrieved from http://www.presscouncil.org.au/uploads/52321/ufiles/The New_York Times_In novation Report - March 2014.pdf

The Newspaper Works. (2015). Digital readership leaps by 9 per cent! Retrieved February 25, 2015, from http://www.thenewspaperworks.com.au/digitalreadership-gains-offset-print-result/

The Pew Research Center. (2013). The state of the news media 2013: Key findings. Retrieved from http://www.stateofthemedia.org/2013/overview-5/key-findings/ 